Raymond Colle, Francisco Campos, Joan Francesc Fondevila, Javier Bustos, Jaime Novoa

\title{
Estudios sobre la prensa digital iberoamericana
}
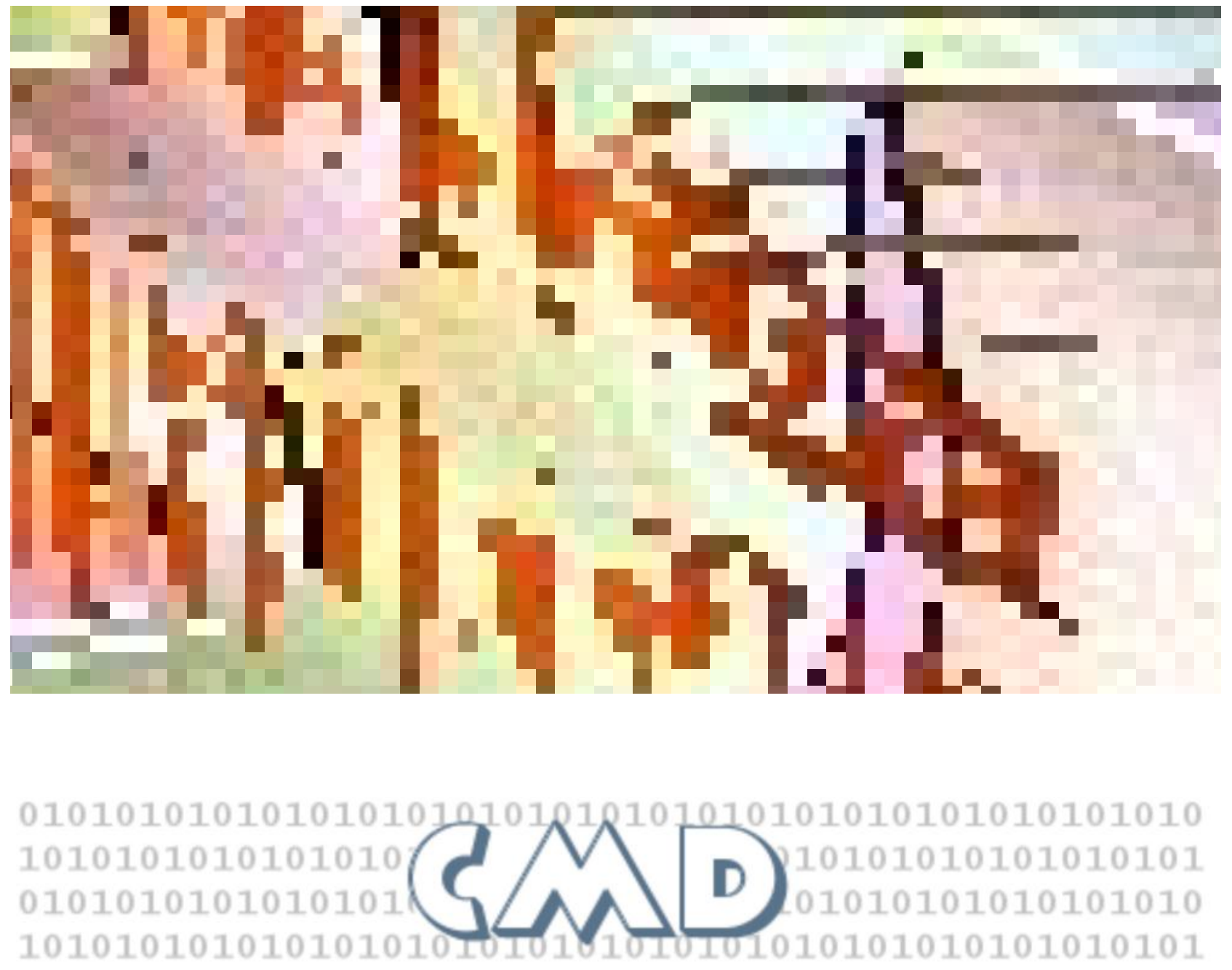

Colección Mundo Digital / 5

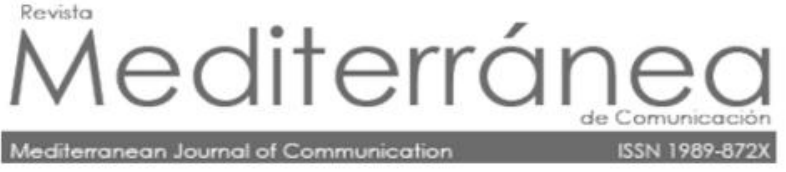


Estudios sobre la prensa digital iberoamericana

Autores principales: Raymond Colle, Francisco Campos, Joan Francesc Fondevila Gascon, Javier Bustos Díaz, Jaime Novoa

Colaboradores de investigaciones incluídas: Diana Rivera, Jenny Yaguache, Ana

Beriain Bañares, Marc Perelló Sobrepere, Victoria Barbero González

Producido en Santiago de Chile, 2014

ISBN: 978-956-353-778-9

Editor / Coordinador de la Colección: Dr. Raymond Colle

Directora: Dra. Victoria Tur Viñes (Revista Mediterránea de Comunicación)

Ilustración de portada: R.Colle

Selecciona y difunfe: Revista Mediterránea de Comunicación, Alicante (España)

(http://mediterranea-comunicacion.org/index.php/Mediterranea)

(c) ()

*Queda expresamente autorizada la reproducción total o parcial de los textos publicados en este libro, en cualquier formato o soporte imaginable, salvo por explícita voluntad en contra del autor o autora o en caso de ediciones con ánimo de lucro, señalando siempre la fuente. Las publicaciones donde se incluyan textos de esta publicación serán ediciones no comerciales y han de estar igualmente acogidas a Creative Commons. Harán constar esta licencia y el carácter no venal de la publicación. 


\section{Tabla}

Introducción, p.5

1. Morfología de los principales diarios digitales iberoamericanos

(Raymond Colle)

1.1. Introducción, p.7

1.2. Metodología, p.8

1.2.1. Muestra, p.8

1.2.2. Variables, p.9

1.3. Resultados, p.11

1.3.1. Aspectos generales, p.11

1.3.2. Portadas, p. 15

1.3.3. Cuerpo variable de las portadas, p. 18

1.3.4. Páginas interiores, p. 22

1.4. Crítica, p. 27

1.4.1. "Tienes 15 segundos", p.27

1.4.2. Página interior, $\mathrm{p} .36$

1.4.3. ¿Recopilar (y analizar) big data o little data?, p.38

1.5. Conclusión, p. 40

1.6. Bibiografía, p. 41

2. La agenda temática digital de la prensa latinoamericana (Francisco Campos)

2.1. Introducción, p.43

2.2. Método, p.47

2.2.1. Estrategias e instrumentos de investigación, p.47

2.2.2. Procedimiento de análisis, p.49

2.3. Resultados, p.49

2.4. Conclusiones, p.55

2.5. Referencia bibliográficas, p.56

3. Estudio de caso de prensa digital internacional: hipertextualidad, multimedia e interactividad en USA Today, Le Monde, The Telegraph y Clarín (Joan Francesc Fondevila Gascon \& col.)

3.1. Introducción, p.58

3.2. Sociedad de la Banda Ancha y Prensa Digital, p.59

3.2.1. La hipertextualidad, p.59

3.2.2. Elementos multimedia, p. 60

3.2.3. La interactividad, p.61

3.3. Metodología, p. 62

3.4. Resultados, p.62 
3.5. Conclusión, p.66

3.6. Referencias bibliográficas, p.67

4. Polarización mediática vs Polarización en las redes-sociales:

Estudio de los perfiles de El-País y El-Mundo en Twitter

(Javier Bustos Díaz)

4.1. Introducción, p.70

4.2. Medios de comunicación, p.71

4.3. Datos extraídos del debate del estado de la nación, p. 75

4.4. Conclusiones, p.78

4.5. Bibliografía, p.78

5. Obtención de una visión particular de las comunicaciones en Iberoamérica a través de la prensa digital (Raymond Colle)

5.1. Introducción, p. 80

5.2. Etapas, p. 81

5.2.1. Diseño, p.81

5.2.2. Registro y visualización de los datos, p. 83

5.2.3. Consolidación de datos, p. 85

5.3. Análisis de lo obtenido, p. 85

5.3.1. Localización, p. 85

5.3.2. Temática, $p .87$

5.3.3. Implicados, p. 90

5.3.4. Síntesis por país, p. 92

5.4. Conclusión, p.95

5.5. Bibliografía, p.96

6. La prensa digital en España: los errores del pasado, las oportunidades del futuro (Jaime Novoa)

6.1. Introducción, p.97

6.2. Del papel hacia lo digital, p. 98

6.3. La información gratuita que ¿convive? con la de pago, p.99

6.4. El periodismo, ¿en peligro?, p.101

6.5. La necesidad o no de una 'tasa Google', p.101 


\section{(.) \\ Introducción}

Cuando en 1994/95 la World Wide Web dejó el mero ambiente académico para abrirse a todos, la prensa fue uno de los primeros sectores en adoptar esta tecnología aunque, hasta el día de doy, sigue buscando la mejor forma de hacerlo y de superar las dificultades financieras que esta nueva vía de difusión de noticias trajo consigo. Los diarios han debido adaptarse tanto a un nuevo formato (las páginas web y su "multimedialidad") como a un nuevo ritmo de difusión, antes más bien propio de la radio, y al surgimiento de sistemas complementarios -a veces competidores- como las redes sociales.

En la presente obra, hemos reunido varios trabajos que abordan distintos aspectos de la problemática actual, sin pretender en absoluto abarcarlos todos ni asegurar que abordamos los más importantes, ya que el contenido reunido ha dependido en gran parte de las respuestas al Call for papers de Revista Mediterránea de Comunicación.

El primer capítulo corresponde a una investigación del coordinador de la colección, Raymond Colle, que realizó una revisión de la forma en que aparecen 13 diarios iberoamericanos. Su conclusión es que, a pesar de usar recursos técnicos actualizados, en su formato y despliegue estos periódicos, en general, se inspiran aún quizás demasiado del modelo impreso, sin una suficiente optimización para responder a las necesidades de sus lectores y sin una suficiente aplicación de las reglas del diseño centrado en el usuario web.

El segundo capítulo, de Joan Francesc Fondevila Gascon, complementa muy bien el anterior, con un análisis del uso que hace de la hipertextualidad, el multimedia y la interactividad la prensa digital internacional. Estas tres variables son los pilares fundamentales que caracterizan el periodismo digital, por lo que su estudio sirve para conocer precisamente en qué fase evolutiva se encuentra el mismo y cómo se relaciona el público con este cada vez menos nuevo medio. Revisa y compara cuatro diarios de diversos países y en diferentes idiomas, uno de ellos argentino -Clarín' - (razón de la presencia de su informe en esta obra). Los otros diarios son 'Le Monde', 'USA Today' y 'The Telegraph'.

El siguiente capítulo recoge un estudio de Javier Bustos Díaz acerca de los perfiles de los diarios El País y El Mundo en Twitter, comparando la polarización ideológica de éstos en esta red social con la polarización en su publicación habitual. Descubrió una tendencia que está extrapolando el liderato de los principales medios de comunicación en España a la red social Twitter, hecho que replica el modelo pluralista polarizado que 
se da en el mundo off-line al mundo on-line.

El cuarto capítulo aborda la prensa digital regional como fuente de información sobre la situación de las comunicaciones en Iberoamérica. ¿En que medida, solo mediante consultas regulares en la web, es posible obtener una visión de conjunto? ¿Cuáles son las principales dificultades y cuáles los vacíos? Concluye que los diarios españoles y un diario chileno son los que mejor informan sobre lo que ocurre en la región pero que, para una visión más completa sin quedar submergido por material que no viene al caso, se necesita recurrir a lectores de RSS con filtros, aunque no todos los países tienen diarios digitales con esta modalidad de difusión.

Terminamos con un comentario de Jaime Novoa sobre la prensa digital en España, donde señala errores cometidos en el pasado e indica las oportunidades que ofrece el futuro. Nos recuerda especialmente que, en el entorno actual, el valor monetario de la información en sí (los artículos, las noticias) se diluye. Y no duda en considerar que Google "es un partner importante y necesario en el mundo de la información e internet”. 


\title{
证
}

\section{Morfología de los principales diarios digitales iberoamericanos}

\author{
Dr. Raymond Colle \\ Ex-profesor Pontificia Universidad Católica de Chile \\ y Universidad Diego Portales \\ Santiago de Chile \\ raymondcolle@gmail.com
}

\subsection{Introducción}

El análisis de contenido es el conjunto de los métodos y técnicas de investigación destinados a facilitar la descripción sistemática de los componentes semánticos y formales de todo tipo de mensaje, y la formulación de inferencias válidas acerca de los datos reunidos. Aunque, según Miguel de Moraga, el objeto final del análisis de contenido es siempre el significado, la "componente expresiva" es parte del mensaje y puede ser estudiada en sí-misma (de Moraga, p.35) y no faltan los métodos que apuntan a dicha componente. En 1974, Roger Mucchielli incluía las técnicas lógicoestéticas y formales -o morfológicas- como una de las tres categorías principales de análisis de contenido. Éstas centran su preocupación en los "procedimientos de expresión utilizados por el emisor, buscando características de estilo, vocabulario, efectos estéticos y retóricos u otros" (Mucchielli, p.27).

Jacques Kayser propuso en 1961 un modelo de análisis morfológico que aplicó a la prensa francesa. Consideraba que de lo que más se impregna el lector era menos del texto en sí que de la forma del texto, captada por los ojos y luego registrada en la memoria. Por ello, estimaba que los factores externos conferían a la información un valor peculiar, un periódico formando un todo, una unidad en la que ningún elemento es disociable sin que se altere su autenticidad (Colle, tomo 2, p.67).

Con el desarrollo de internet y la aparición de los periódicos digitales resulta evidente que la propuesta de Kayser contiene numerosas variables que no son aplicables a esta nueva modalidad de comunicación periodística y que ahora le faltan muchas otras. En el presente trabajo, proponemos una lista de variables más adecuada tomando en cuenta las exigencias fundamentales de la comunicación actual en web: 
hipertextualidad, navegabilidad y adaptación a la recepción en diferentes tipos de equipos (diseño de interfaz). Aplicamos estos criterios a los principales diarios iberoamericanos (11 diarios nacionales latinoamericanos y 2 españoles).

Nuestra conclusión es que, a pesar de usar recursos técnicos actualizados, en su formato y despliegue se inspiran aún demasiado -en general- del modelo impreso, sin una suficiente optimización para responder a las necesidades de sus lectores.

\subsection{Metodología}

El presente estudio, de tipo exploratorio, se concentra en la forma en que aparecen en la World Wide Web los diarios seleccionados. Para cada diario se han tomado en cuenta los dos principales tipos de despliegue de noticias: la portada o home page y una página "interior" propia de una noticia específica, en este caso la que parecía destacada en la portada. Se tomaron en cuenta los mecanismos de navegación (enlaces) y diversos factores ligados a otros recursos de internet, como la existencia de versiones móviles y la presencia en las redes sociales.

El levantamiento inicial de datos se hizo el 9 de enero 2014 entre las 14 y las $16 \mathrm{hrs}$ GMT, procediéndose a descargar completamente y almacenar en el PC la portada (página de inicio o home page) y a tomar pantallazos en 75\% de ésta y de la página interior seleccionada (en una pantalla de PC Full HD 1920x1080px), tamaño que se redujo posteriormente según las necesidades en el caso de las ilustraciones incluidas en el presente trabajo.

El Comercio de Perú cambió su interfaz de portada el día 10 de enero, es decir el día siguiente de nuestro "levantamiento". Advertidos de ello ese día, verificamos que la descarga de la portada era muchísimo más lenta y las imágenes no llegaban a aparecer, por lo que reingresamos y descargamos la nueva versión, ya corregida, el día 14, tomando nuevos "pantallazos". Las páginas interiores (incluso las de días anteriores aún accesibles) también se han ajustado al nuevo formato. Los cálculos y comparaciones se hicieron sobre la base de esta nueva versión.

\subsubsection{Muestra}

Siendo imposible considerar todos los diarios iberoamericanos que podrían tener una versión digital, se han seleccionado los que, en América Latina, pertenecen al "Grupo de Diarios América” (GDA) y, para la península, El País y El Mundo, por su amplia difusión ${ }^{1}$. Los enlaces considerados ha sido los siguientes:

1 Según ComScore, que indica que El País y El Mundo tienen el mayor número de visitas online (PC + móviles). 
Grupo GDA: Argentina: La Nación, http://www.lanacion.com.ar

Brasil: O Globo, http://www.oglobo.com.br/

Chile: Emol (El Mercurio Online), http://www.emol.com/

Colombia: El Tiempo, http://eltiempo.com/

Costa Rica: La Nación, http://www.nacion.com/

Ecuador: El Comercio, http://www.elcomercio.com/

México: El Universal, http://www.el-universal.com.mx/

Perú: El Comercio, http://elcomercio.pe/

Puerto Rico: El Nuevo Día, http://www.endi.com/

Uruguay: El País, http://www.elpais.com.uy/

Venezuela: El Nacional, http://www.el-nacional.com/

España: El Mundo, http://www.elmundo.es/

El País, http://www.elpais.es/

\subsubsection{Variables}

Para la definición de las variables de análisis, además de los propios y aplicables de los aspectos morfológicos de las portadas de diarios impresos, se tomaron en cuenta criterios generales del campo de la informática como los relativos al diseño de interfaces de usuarios y a la "navegabilidad" (veáse especialmente Krug y Nielsen). Como lo señaló correctamente Joao Canavilhas en su tesis doctoral (2007, p.204), "el trípode del webperiodismo" se compone de la hipertextualidad, la multimedialidad y la interactividad e incluímos estos tres aspectos en nuestras variables.

Para el levantamiento de datos y el trabajo comparativo se recurrió a una planilla Excel con filas correspondientes a las variables y columnas a los diferentes periódicos.

Las variables seleccionadas fueron las siguientes:

a. Aspectos generales

Ancho del espacio ocupado en pantalla (en pixeles), fijo o variable

Tipo de componentes que se decargan junto con las páginas HTML

Construcción de las páginas (columnas, orden de lectura...)

Existencia de versión móvil diferente de la versión para PC (con o sin app especial)

Existencia de versión digital de la versión impresa

Presencia en redes sociales

Acceso con contraseña

b. Portada

$\mathrm{N}$ total de componentes además del HTML (JPG, GIF, JS, CSS)

Extensión (en pantallazos, traducidos después en total aproximado de pixeles) 
Contenido de la cabecera (banner superior)

Color de fondo

Nombre del diario

Acceso a versiones anteriores, versión impresa, mapa del sitio

Medios sociales: Facebook, Twitter, RSS, Otros

App descargable

Buscador

Barras de navegación (ubicación y formato)

Contenido de la portada

Color de fondo general

Otros fondos de color

$\mathrm{N}^{\circ}$ de columnas en primera pantalla visible

Cambio del $\mathrm{n}^{\circ}$ de columnas al avanzar

$\mathrm{N}^{\circ}$ de noticias en columna principal (aproximado)

$\mathrm{N}^{\circ}$ de noticias con foto / con video / sin imagen

$\mathrm{N}^{\circ}$ noticias con lead (título y texto)

Primeras noticias (prioridad): noticias sobre política nacional, de la capital, internacionales, deporte... ?

Enlaces a destacados

Producto de estadística: "Lo más leído" Sí/No

Úlimo minuto o hora

Versión impresa

Suscripciones

Blogs

Columnas de opinión

Mecanismo de retroalimentación

Club de suscriptores

Informaciones útiles: (Monedas, meteo, bolsa...)

Especiales / suplementos

Edición TV

Avisos publicitarios

Banner inferior (pie)

Cambio en número de columnas

Identidad comercial

Productos asociados / red empresarial

Mapa del sitio

Legal: Términos y condiciones - Política de privacidad

Reclamaciones

Contacto

"Trabaja con nosotros"

Membresías (GDA / otras)

Certificadores - Estadística externa 
b. Página "Interior"

Cabecera:

Idéntica a portada o Diferente

Navegación a otras secciones: Idéntica o diferente

Artículo:

Titulación: Igual o diferente de la portada

Mención de sección

$\mathrm{N}^{\circ}$ de columnas que ocupa

$\mathrm{N}^{\circ}$ de otras columnas

Posibilidad de ingresar comentarios

Enlaces dentro del texto

Enlaces a otros artículos

Títulos

Viñetas

Tags (etiquetas)

Última hora

\subsection{Resultados}

Todos los datos corresponden a las versiones observadas y "fotografiadas" en las fechas señaladas y debe considerarse, en consecuencia, que algunos pueden variar según la fecha (como la cantidad de noticias e incluso de columnas, por lo que hemos podido observar).

\subsubsection{Aspectos generales}

\subsubsection{Ancho del espacio ocupado en pantalla}

El ancho se midió en pixeles después de abrir nuestro navegador a pantalla completa. Todos los diarios han resultado de un ancho menor al que nos ofrecía nuestra pantalla y medimos el ancho real que ocuparon, excluyendo la publicidad que algunos ponían en columnas exteriores (fuera del ancho determinado por la cabecera y las barras de menú, lo cual no es generalizado) y solo ocupa una parte del espacio superior (ejemplo en la ilustración que sigue, copiada en una fecha posterior). 
Ilustración 1. Diario con publicidad "exterior" a su portada

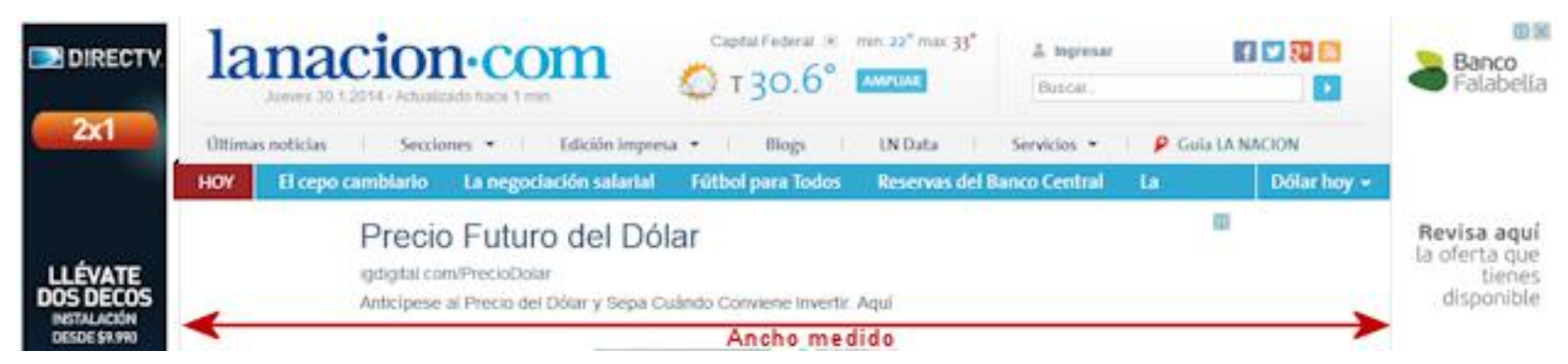

Todos los diarios han establecido un ancho fijo para la recepción en PC, el que varió en cada caso entre un mínimo de 960 pixeles y un máximo de 1028. El País midió 1000 pixeles y El Mundo 1028, mientras El Comercio (Pe) fue el único del Grupo GDA en medir más de 1000 pixeles (1020). 1020 es un ancho típico de pantalla en muchos monitores de PC, aunque ya son frecuentes monitores mayores.

En el caso de la recepción en móviles, el ancho es dinámico, como se señala más adelante.

\subsubsection{Tipo de componentes}

Las páginas web de hoy no se componen exclusivamente de código HTML con eventual inserción de imágenes. En consecuencia, para observar el modo de operar de los diarios es necesario descargar en forma completa una copia de la home page. Se obtiene así una copia del código HTML, que es el que determina el despliegue de todos los elementos, junto con todos estos. La forma de presentación (estilo, recuadros, etc.) queda establecida en la (o las) "hoja(s) de estilo". También cuentan generalmente con código JavaScript (que controla algunas actuaciones del ratón). Todo ello va acompañado de las imágenes, que pueden estar en formato Jpeg, PNG y Gif. Todos los diarios considerados tienen estos diferentes elementos pero su cantidad total puede variar notoriamente (vea apartado 1.3.2.1.), como indicamos en la siguiente tabla.

Tabla $1 . \mathrm{N}^{\circ}$ de componentes

\begin{tabular}{lc|}
\hline Diario & $\mathrm{N}^{\circ}$ \\
\hline Comercio.ec & 154 \\
Comercio.pe & 42 \\
EIMundo & 117 \\
EINacional & 162 \\
EINuevoDía & 167 \\
Emol & 182 \\
EIPaís.es & 28 \\
EIPaís.uy & 135 \\
EITiempo & 166 \\
ElUniversal & 231 \\
LaNación AR & 82 \\
LaNación CR & 119 \\
O Globo & 158
\end{tabular}




\subsubsection{Construcción de las páginas}

Debajo de una cabecera a todo el ancho, las páginas son divididas, en forma generalizada, en tres columnas verticales, las que -en las portadas- suelen subdividirse en algunos segmentos de la página. Las portadas son también más extensas que las páginas interiores. No hay acuerdo sin embargo en torno a la extensión de las portadas (con desplazamiento vertical mediante scrolling) y las diferencias pueden ser muy significativas. Dado que hemos tomado pantallazos para poder conservar una visión completa de las páginas seleccionadas, tenemos una medición que va desde 4 (El Nuevo Día) hasta 13 pantallazos o clics de ratón (El País.es y La Nación.ar) para avanzar renovando el contenido de la pantalla, equivalentes a un mínimo de 4.260 y un máximo de 13.860 pixeles aproximados (Ver Ilustración 2). En el caso de las páginas interiores, la norma es 2 pantallas y ocasionalmente $3 .^{2}$

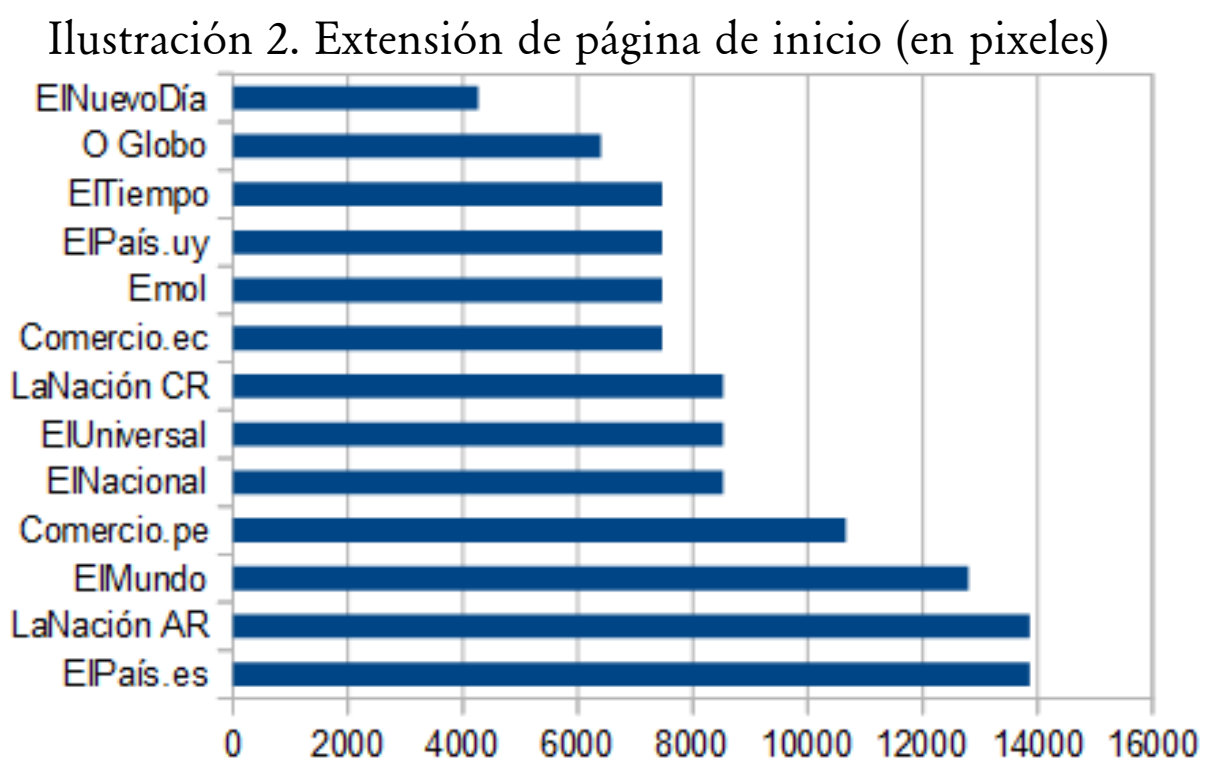

Analizamos en detalle las diferencias en los apartados 1.3.3.4. y 1.3.3.6. La longitud de la home page merece un comentario especial en el apartado 1.4.

Las páginas cuentan con un "pie" que se repite generalmente tanto en la portada como en las páginas "interiores". Se analiza en detalle en el apartado 1.3.2.3.

\subsubsection{Versiones móviles}

La mayor parte de los diarios presentan la misma versión web en PC y equipos móviles, con ancho dinámico para estos últimos (se ajusta a la pantalla, con las mismas columnas pero más estrechas, función realizada normalmente por el navegador). Todos admiten el zoom con movimiento de dedos en los móviles. El Comercio (Ec), Emol,

2 Nota acerca de las mediciones: El número de pantallazos es el que obtuvimos en nuestro PC de pantalla utilizando el navegador Chrome con reducción a 75\% (lo cual puede estar más cerca de las pantallas comunes, ya que la nuestra es extra-grande). La medición en pixeles es la real en base a pantallazos al 100\%, aunque puede variar según el tamaño de letra definido en el navegador. 
La Nación (CR) y El Nuevo Día tienen una versión especial para móviles que reconoce el tipo de equipo y se despliega automáticamente en éstos. O Globo y El Nuevo Día también tienen una "app" especial que se puede descargar en el móvil. El Mundo tiene la habitual versión de PC que se ajusta en el móvil y otra versión que evita la multiplicidad de columnas (sin necesidad de una app especial).

\subsubsection{Versión digital de la versión impresa}

Los diarios que producen y permiten el acceso a una versión digitalizada de su publicación impresa son 6, mientras 7 no la mencionaron en su portada. Esta versión puede ser visualizada con diferentes recursos que pueden o no ser integrados al navegador (como Flash Player u otro). En varios casos estas versiones solo son accesibles para suscriptores, por lo que no analizamos los detalles correspondientes.

\subsubsection{Presencia en redes sociales}

Todos los diarios mencionan que tienen presencia en las redes sociales, la más común siendo Facebook y la menos frecuente Instagram. En algunos casos el ícono de enlace está en la cabecera y en otros casos en el cuerpo de la portada. Algunos ofrecen además sindicación (RSS, para aplicaciones de lectura de noticias). Detallamos esta situación en la Tabla 2.

Tabla 2. Presencia en las redes sociales

\begin{tabular}{|lllrlll|}
\hline \multicolumn{1}{|c}{ Diario } & & Pos. Facebook & Twitter & G+ & RSS Otro \\
El Comercio (Ecuador) & $\mathrm{B}$ & + & + & - & + & - \\
El Comercio (Perú) & $\mathrm{B} \mathrm{C}$ & + & + & + & - & - \\
El Mundo (España) & $\mathrm{B}$ & + & + & + & - & - \\
El Nacional (Venezuela) & $\mathrm{B}$ & + & + & + & + & Pinterest+Instagram \\
El Nuevo Día (Puerto Rico) & $\mathrm{B} \mathrm{C}$ & + & - & - & - & - \\
Emol (El Mercurio) (Chile) & $\mathrm{C}$ & + & + & - & - & - \\
El País (Es) & $\mathrm{C}$ & + & + & + & + & - \\
El País (Uruguay) & $\mathrm{B}$ & + & + & - & + & - \\
El Tiempo (Colombia) & $\mathrm{B}$ & + & + & + & - & - \\
El Universal (México) & $\mathrm{B}$ & + & + & - & + & - \\
La Nación (Argentina) & $\mathrm{B}$ & + & + & + & + & - \\
La Nación (Costa Rica) & $\mathrm{B}$ & + & + & + & - & Instagram \\
O Globo (Brasil) & $\mathrm{B}$ & + & + & + & - & - \\
\hline
\end{tabular}

* Posición (Pos.): B significa en cabecera (banner), C en el cuerpo. Los signos son de presencia $(+)$ y ausencia (-).

\subsubsection{Acceso reservado}

Uno solo de los diarios considerados (El Mundo) muestra un "muro de pago" mientras otros 8 ofrecen un mecanismo de suscripción gratuito para acceder a ciertas 
informaciones o servicios complementarios (como el envío de noticias al correo electrónico del suscriptor). Aunque Emol no presenta mecanismo de suscripción, los suscriptores de la versión impresa del diario (El Mercurio) tienen acceso a una versión digital (diario.elmercurio.com) a la que pueden ingresar con su número de identidad nacional y contraseña.

\subsubsection{Portadas}

\subsubsection{Número de componentes}

Todos los diarios considerados tienen los diferentes elementos (Jpeg, Png Gif, CSS, JS) pero su cantidad total puede variar notoriamente, como indicamos en la tabla 3.

Tabla 3. Componentes técnicos de las portadas

\begin{tabular}{|l|c|}
\hline Diarios & N$^{\circ}$ de componentes \\
\hline El Comercio (Ecuador) & 154 \\
El Comercio (Perú) & 42 \\
El Mundo (España) & 117 \\
El Nacional (Venezuela) & 162 \\
El Nuevo Día (Puerto Rico) & 167 \\
Emol (El Mercurio) (Chile) & 182 \\
El País (Es) & 28 \\
El País (Uruguay) & 135 \\
El Tiempo (Colombia) & 166 \\
El Universal (México) & 231 \\
La Nación (Argentina) & 82 \\
La Nación (Costa Rica) & 119 \\
O Globo (Brasil) & 158 \\
\hline
\end{tabular}

Obviamente las cifras mencionadas son propias del día de publicación considerado. Sin embargo están relacionadas con la extensión de las portadas, las que también varían ampliamente (ver 1.3.1.3.) pero indican diferentes criterios de diseño de las portadas.

\subsubsection{Cabecera}

La cabecera, además de contener el nombre del periódico, puede contener múltiples otros elementos y diferenciarse por elementos estilísticos. Así, 9 de los diarios tienen una cabecera de fondo blanco, mientras una es gris (El Nuevo Día), y las otras naranja (El Comercio .pe) y azul (El Nacional). 


\section{Barras de menú}

El elemento más común esperable es una barra de menú que permita navegar hacia las diferentes secciones, pero puede haber más de una y la posición que ocupa(n) puede variar, como también la forma en que opera (llevando un enlace que lleve directamente a otra página o bien desplegando otro menú).

Tienen una barra encima de su nombre, siempre con enlaces directos: El Comercio (Ecuador), El Comercio (Perú), Emol, El Nacional, El País (Uruguay), El Universal (México), La Nación (Argentina) y O Globo.

Tienen un menú con enlaces directos al lado de su nombre El País de España y El País de Uruguay, pero muy diferentes, siendo menos visible en el dirario uruguayo, debajo del recuadro de búsqueda (Ilustraciones 3 y 4 ).

Ilustración 3. Cabecera El País de España

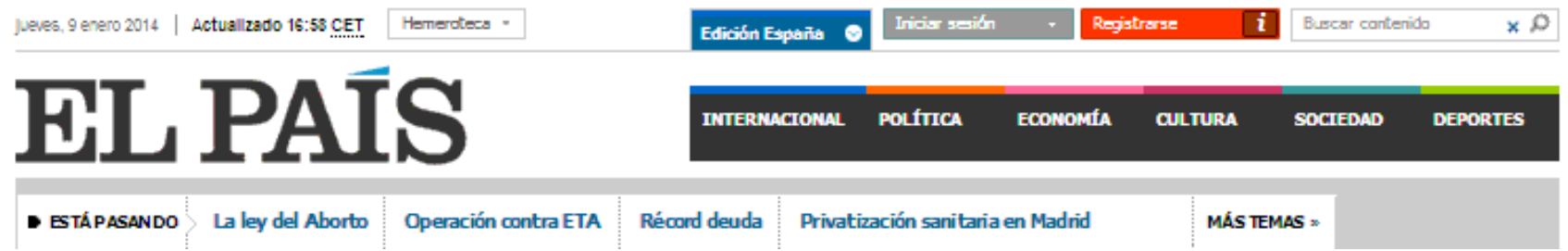

Ilustración 4. Cabecera El País de Uruguay

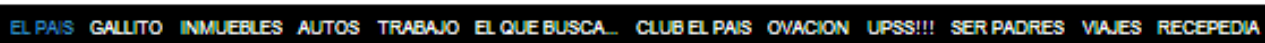

FL PAIS com。iuy thes

Home Informaxión Mundo Vidaactual Opinión Bconomía Ovación TVShow Divertite servios $⿴$ mas $⿴$

La barra de navegación que está debajo del nombre es de enlaces en el caso de El Comercio (Ecuador), El Comercio (Perú), El Nuevo Día, Emol, El País (Es), El Tiempo y La Nación (Costa Rica). Es de menú desplegable para El Mundo, El Nacional, El País (Uruguay), El Universal, La Nación (Argentina) y O Globo.

Algunos diarios tienen aún otra barra, de enlaces, bajo la anterior, como es el caso de El Comercio (Perú), La Nación (Argentina) y O Globo.

Fecha y hora

Son 10 los diarios que colocan la fecha y hora en su cabecera, mientras dos colocan solamente la fecha (El Tiempo y El Comercio de Perú) y El Nuevo Día no los coloca ahí sino en el cuerpo variable. 
Acceso a otras versiones

En algunos casos existen botones que permiten acceder a otras versiones:

- a versión impresa (digitalizada): La Nación (Argentina)

- a versiones anteriores: El Comercio (Ecuador), El País (Uruguay), El Universal, El Comercio (Ecuador), El País (Es), El Universal.

Mapa de sitio

El Comercio (Ecuador) y La Nación (Costa Rica) son los únicos que colocan en su cabecera un acceso al mapa del sitio web.

\section{Otros elementos}

Once diarios ponen en su cabecera enlaces a medios sociales y RSS. Emol y El País (Es) son las excepciones. El Mundo, El Universal y O Globo ponen ahí su acceso a la versión móvil. También ahí se coloca el botón de ingreso para suscriptores cuando existe (ver 1.3.1.7).

Seis diarios ponen en su cabecera información meteorológica: El Nacional, El País (Es), El País (Uruguay), El Universal, La Nación (Argentina) y O Globo.

Once tienen un recuadro de búsqueda. Las excepciones son Emol y O Globo.

Incluyen ahí publicidad: El Mundo, El Nacional, El Universal y La Nación (Costa Rica).

\subsubsection{Pie de página}

El "pie" de página cuenta con la identificación legal del medio de comunicación y algunas otras informaciones que se repiten generalmente tanto en la portada como en las páginas "interiores". Las informaciones y enlaces presentes aquí se agrupan en un número de columnas muy variable y en todos los casos diferente de su número en el cuerpo de la página.

La mayoría de los diarios recurre a una nueva barra de navegación para acceder a estas informaciones o parte de ellas: El Comercio (Ecuador), Emol, El País (Es), El País (Uruguay), El Tiempo, El Universal, La Nación (Argentina), La Nación (Costa Rica) y O Globo.

Podemos encontrar en este menú o con otro enlace acceso a:

- el mapa del sitio: El Comercio (Ecuador), El Nuevo Día, Emol, El País (Es), El Universal, La Nación (Costa Rica) y O Globo; 
- la política de privacidad: El Comercio (Ecuador), El Mundo, El Universal, La Nación (Costa Rica) y O Globo;

- los "términos y condiciones" legales: todos, con excepción de El País (Uruguay);

- una dirección de contacto: El Comercio (Ecuador), El Mundo, El Nacional, El Nuevo Día, El País (Es), El Tiempo, El Universal, La Nación (Costa Rica) y O Globo;

- datos y enlaces de la red empresarial o productos asociados: El Comercio (Ecuador), El Comercio (Perú), El País (Es), El Universal, La Nación (Argentina), La Nación (Costa Rica) y O Globo;

- “Trabaja con nosotros”: El Comercio (Perú), La Nación (Argentina) y O Globo;

Pertenencia

Todos los diarios latinoamericanos seleccionados son miembros de GDA y lo señalan en el pie, con la excepción de La Nación de Costa Rica. Algunos también señalan pertencia a IAB (Interactive Advertising Bureau): El Comercio (Ecuador), El Nacional y El Tiempo. El Universal indica que es controlado por ComScore (compañía de investigación de marketing).

Publicidad

El Mundo, Emol, El País (Es) y La Nación (Argentina) colocan publicidad dentro de esta sección; mientras los otros lo evitan.

\subsubsection{Cuerpo variable de las portadas}

\subsubsection{Aspectos formales generales}

Todos los diarios utilizan un fondo blanco, menos El Nacional que utiliza un fondo de un gris azulado claro. Once de los trece insertaron también cuadros con otros colores de fondo, menos La Nación de Costa Rica y O Globo.

El Comercio de Perú inicia el cuerpo con la fecha y hora de su última noticia y El Nuevo Día con la fecha, cosa que no hacen los demás.

La mayoría de los diarios presentan tres columnas, salvo El Mundo, El Nacional y El Nuevo Día que ponen 4. Tres utilizan una de estas columnas para desplegar un menú de acceso a otras secciones del diario: El Mundo, El Nuevo Día y El País (Es). Todos, menos El Comercio de Ecuador, aumentan ocasionalmente el número de columnas después de la primera pantalla. 


\subsubsection{Noticias de la columna principal}

Definimos como "columna principal" la columna de texto en que aparece la primera noticia de portada, debajo de la cabecera, generalmente la primera o la segunda columna a la izquierda y frecuentemente más ancha que las otras.

\section{Conteo de noticias}

A veces esta columna principal se divide en dos, en cuyo caso hemos considerado las dos para revisar las noticias. La cantidad, sin embargo, es aproximada por cuanto puede haber cuadros que pertenecen a otras secciones siendo a veces difícil definir si es noticia o no sin acceder a la página correspondiente (lo que no hicimos).

Tabla 4. Cantidad de noticias en columna principal de portada

\begin{tabular}{|l|c|}
\hline Diarios & No $^{\circ}$ \\
\hline El Comercio (Ecuador) & 55 \\
El Comercio (Perú) & 51 \\
El Mundo (España) & 25 \\
El Nacional (Venezuela) & 77 \\
El Nuevo Día (Puerto Rico) & 39 \\
Emol (El Mercurio) (Chile) & 28 \\
El País (Es) & 13 \\
El País (Uruguay) & 22 \\
El Tiempo (Colombia) & 18 \\
El Universal (México) & 20 \\
La Nación (Argentina) & 7 \\
La Nación (Costa Rica) & 23 \\
O Globo (Brasil) & 26 \\
\hline Pía haber más noticias en otras columnas, pero no las \\
vimos en cuenta debido a las grandes variaciones observadas.)
\end{tabular}

Características de las noticias

Revisamos la presentación de las noticias computadas, obteniendo los datos de la Tabla 5.

El Comercio de Perú se destaca por iniciar su portada con un secuencia de fotos que ocupa casi completamente la primera pantalla visible (Ilustración 5). La Nación de Argentina sigue una práctica similar mientras los demás diarios solo ponen una foto (o eventualmente 2 pequeñas) al inicio del cuerpo de la portada. 
Tabla 5. Características de las noticias consideradas

\begin{tabular}{|l|c|c|c|}
\hline Diarios & Con foto & Sin imagen* & Con lead o subtítulo \\
\hline El Comercio (Ecuador) & 20 & 30 & 16 \\
El Comercio (Perú) & 46 & 5 & 31 \\
El Mundo (España) & 11 & 12 & 24 \\
El Nacional (Venezuela) & 23 & 54 & 20 \\
El Nuevo Día (Puerto Rico) & 20 & 19 & 26 \\
Emol (El Mercurio) (Chile) & 13 & 18 & 15 \\
El País (Es) & 2 & 11 & 7 \\
El País (Uruguay) & 20 & 1 & 13 \\
El Tiempo (Colombia) & 12 & 5 & 7 \\
El Universal (México) & 1 & 19 & 2 \\
La Nación (Argentina) & 3 & 0 & 18 \\
La Nación (Costa Rica) & 11 & 22 & 9 \\
O Globo (Brasil) & 20 & 5 & 2 \\
\hline
\end{tabular}

* La suma (con foto y sin imagen) puede no coincidir con el número de noticias antes mencionado debido a la posible existencia de vídeos.

Ilustración 5. El Comercio.pe

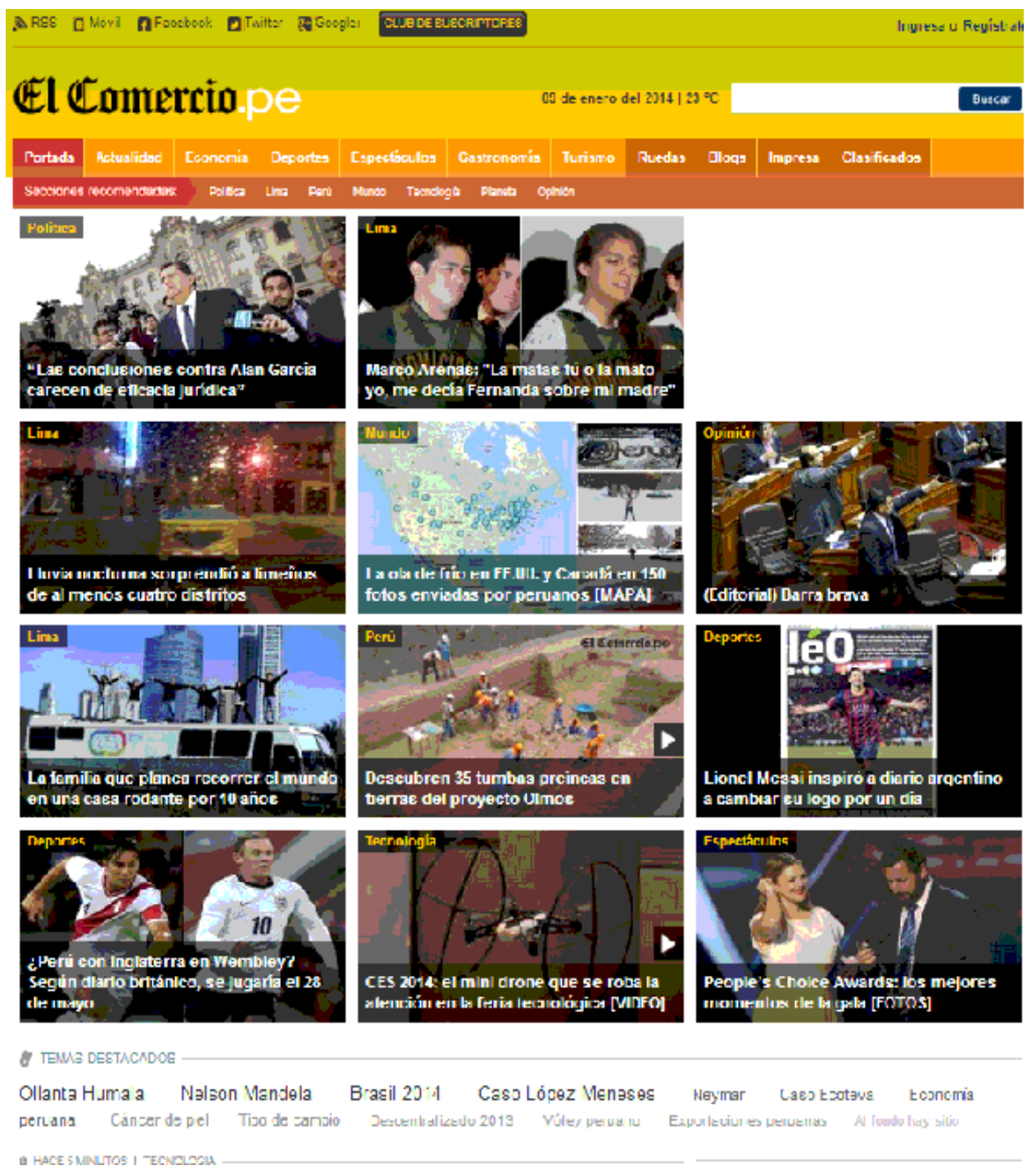


Tipo de noticia prioritaria

Las noticias que aparecen en primer lugar son en todos los casos noticias locales y más frecuentemente de corte político. En la mayoría de los casos (10) es acompañada de una foto. Ninguna deportiva apareció en primer lugar.

\section{Vídeos}

Siete diarios incluyeron vídeos en su portada: El Comercio (Ecuador), El Mundo, El País (Es), El País (Uruguay), El Tiempo, La Nación (Costa Rica) y O Globo.

Otros tipos de enlaces a noticias

Además de los enlaces "ordinarios" de la o las columnas principales, encontramos listas de breves títulos agrupados bajo el título

- “Destacadas": en El Comercio (Ecuador), El Comercio (Perú), El Mundo y La Nación (Argentina);

- "Lo más leído": en El Comercio (Ecuador), El Comercio (Perú), El Mundo, El Nuevo Día, Emol, El País (Uruguay), El Universal (México), La Nación (Argentina) y La Nación (Costa Rica)

- "Último minuto / hora": en El Comercio (Ecuador), El Comercio (Perú), El Nacional, El Nuevo Día, Emol, El País (Es), El País (Uruguay) y La Nación (Costa Rica).

Un caso diferente es el de O Globo que se autoactualiza en pantalla constantemente mientras los diarios que incluyen "Último minuto" se actualizan normalmente cuando el lector recarga la página.

\subsubsection{Otros componentes}

Las portadas contienen muchos otros elementos además de las noticias, como múltiples tipos de enlaces y recuadros publicitarios.

\section{Enlaces}

Además de los enlaces a las noticias, encontramos otros tipos de enlaces como a "Suscripciones" o club de suscriptores, blogs y columnas de opinión, redes sociales, y suplementos (todos mencionan alguno o varios). 
Es notoria la presencia de enlaces a una versión de televisión o "Edición TV", compartida por 7 diarios: El Comercio (Perú), El Mundo, El Nacional, Emol, El País (Es), El País (Uruguay) y El Tiempo, que son los más “multimediales" de los revisados.

\section{Apps}

Solo los diarios españoles, El Mundo y El País, mencionan la disponibilidad de una "app” descargable para acceder a su versión móbil especial.

\section{Publicidad}

Todos incluyen publicidad, en diversos lugares de portada, existiendo también mucha variedad en la forma de presentación. Algunos, como Emol, permiten incluso a particulares "subir" pequeños avisos (Ilustración 6).

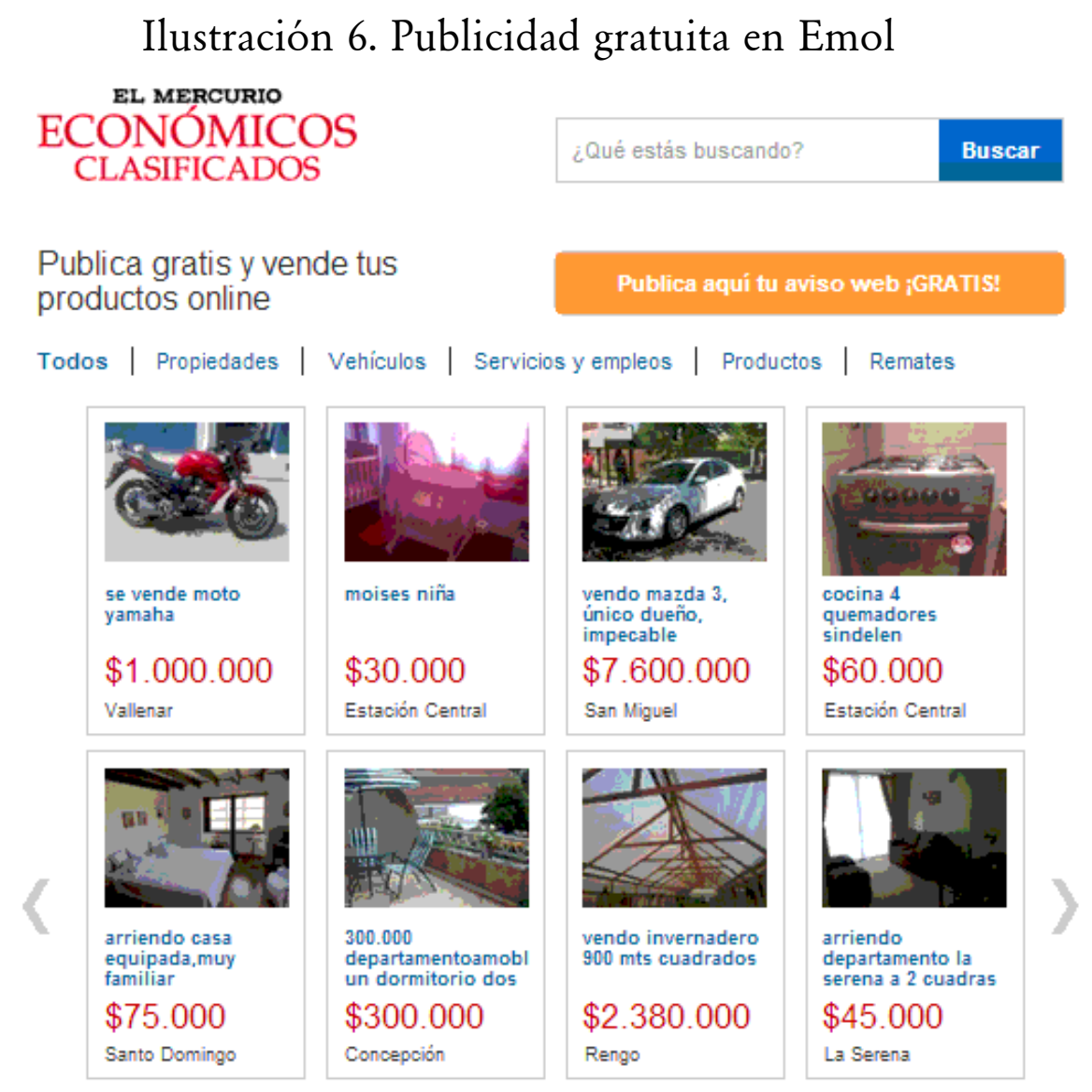

\subsubsection{Páginas interiores}

Seguimos el enlace de la primera noticia que vimos en portada, para conocer el diseño de las páginas "interiores". 


\subsubsection{Cabecera}

Mientras algunos diarios repiten la cabecera de su portada, otros la achican y eventualmente insertan ahí el nombre de la sección. Éste es el caso de El Comercio (Ecuador), El Comercio (Perú), El Mundo, El Nuevo Día, El País (Es), El Universal y O Globo (Ilustración 7).

Ilustración 7. Cabecera interior con sección

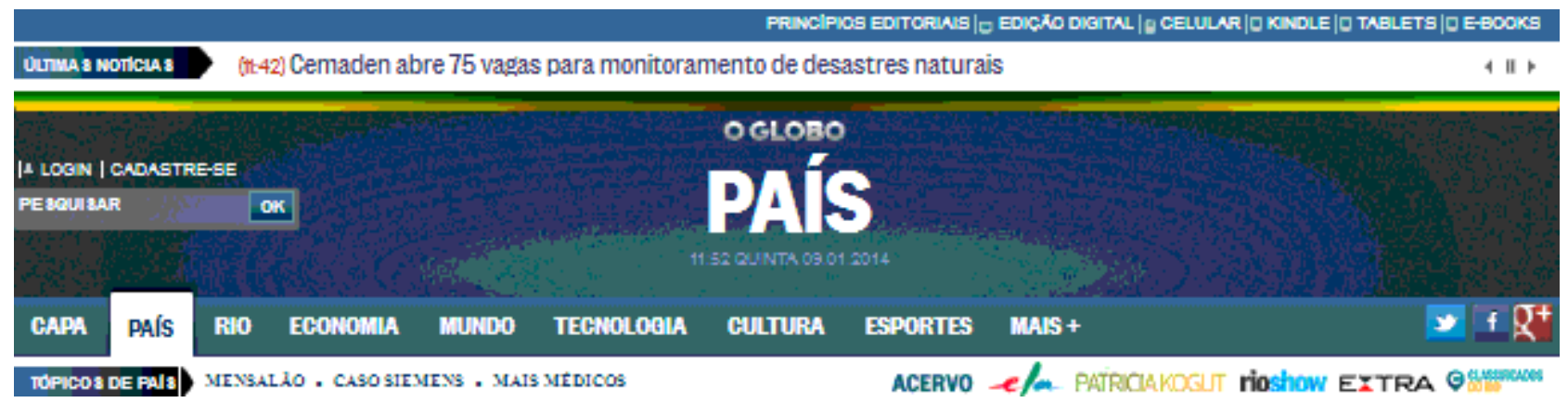

El Nacional y El Nuevo Día mencionan la sección debajo de la barra de menú. El Nuevo Día (Ilustración 8) es el único que señala la sección mediante un menú que corresponde a la secuencia de navegación.

Ilustración 8. Menú-secuencia de navegación del artículo

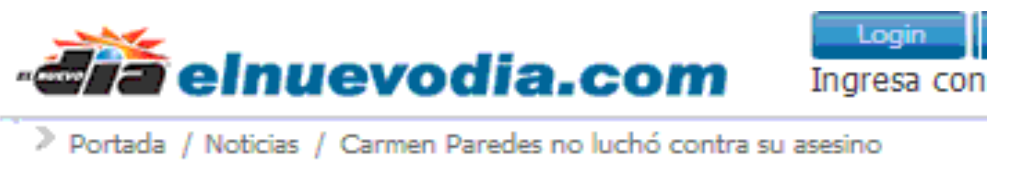

El Tiempo remarca la sección en la barra de menú (lo que otros hacen también, además de señalarla de otra forma).

Solo El Mundo y El País (Es) incluyen una barra de menú diferente de su portada, mientras los otros utilizan la misma que en portada.

\subsubsection{Cuerpo del artículo}

Título

Se anotó aquí si se conservó exactamente o no el título del artículo como apareció en la portada. En este caso, hay coincidencia total en 6 casos: El Comercio (Perú), El 
Nacional, El Nuevo Día, El Tiempo, El Universal y La Nación (Costa Rica). Los otros modifican parcialmente el título.

\section{Disposición}

Emol y La Nación (Costa Rica) son los únicos que ocupan dos columnas. Emol empieza ocupando el ancho de dos columnas con el título y una bajada, para seguir con una foto en la primera columna y el texto en la segunda. Debajo de la foto siguen titulares relacionados (con sus enlaces), para volver al ancho doble de la parte superior para la finalización del texto (Ilustración 9). La Nación (Ilustración 10) trabaja de forma diferente, intercambiando texto con foto en las columnas y ocupando las dos con el texto cuando no tiene foto u otro recuadro (El recuadro a la derecha del vídeo superior contiene enlaces a las últimas noticias).

Ilustración 9. Disposición de Emol

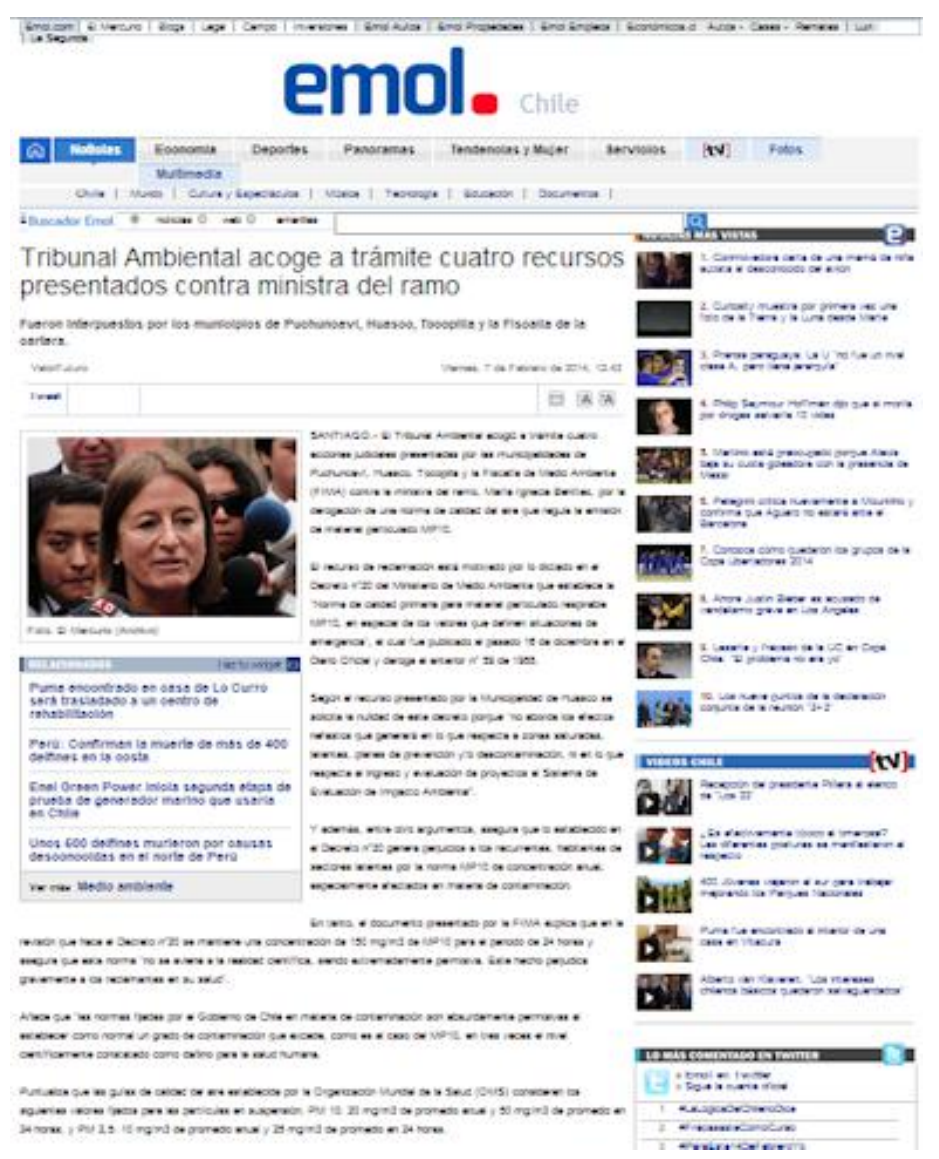


Ilustración 10. Disposición de La Nación (CR)

\section{LA MACIOD насіоNaL.

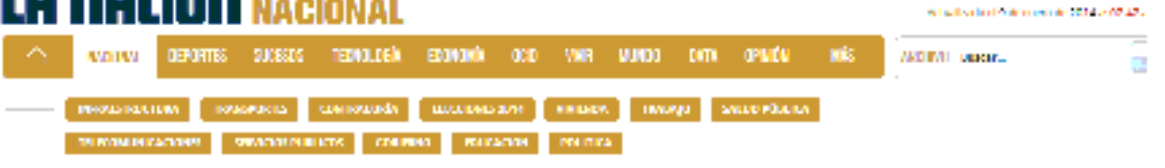
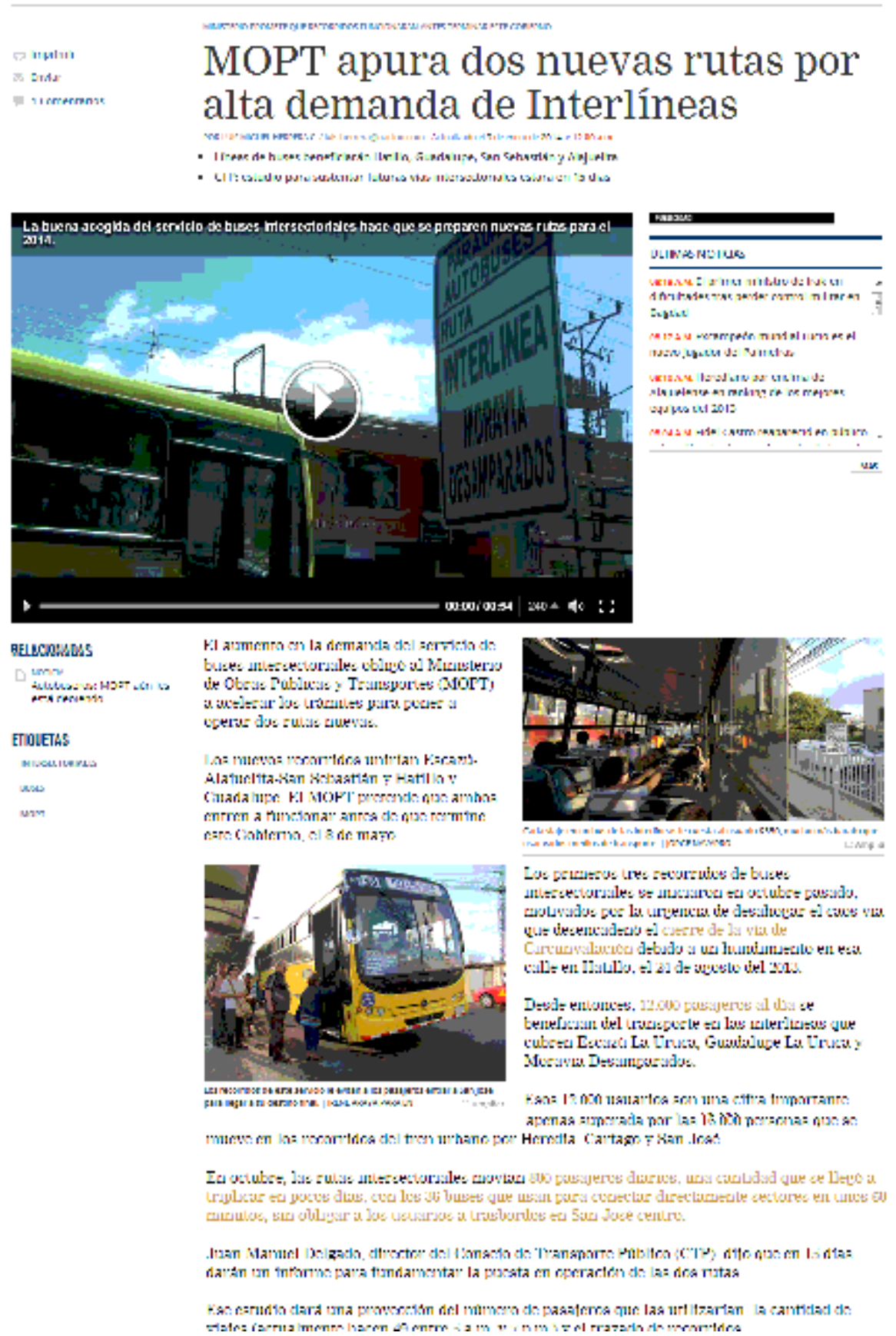

Enlaces complementarios

Es posible colocar enlaces a informaciones complementarias dentro del texto. Lo hacen El Comercio (Ecuador), El Comercio (Perú), El Mundo (Ilustración 11), El País (Es), 
La Nación (Argentina) y La Nación (Costa Rica). Otra modalidad es agregar una serie de "etiquetas" (tags) en una de las columnas o debajo del texto (Ilustración 12). Lo hacen El Comercio (Perú) y La Nación (Costa Rica). Algunos diarios recurren a ambos sistemas.

\author{
Ilustración 11. Enlaces en el texto (El Mundo) \\ El Grupo Vasco cuenta con el apoyo de CiU para solicitar la \\ comparecencia de Fernández Díaz, algo que también ha \\ reclamado hoy $\underline{\mathrm{UPY}}$, en su caso para que explique el "error" \\ cometido ayer cuando se difundió una nota de prensa sobre la \\ operación cuando aún no se habia iniciado.
}

Ilustración 12. Enlaces en etiquetas ( La Nación CR)

\section{ETIQUETAS}

INTERSECTORIALES

BUSES

MOPT operar dos rutas nuevas.

Los nuevos recorridos unirian EscazáAlajuelita-San Sebastián y Hatillo y Guadalupe. El MOPT pretende que ambos entren a funcionar antes de que termine este Gobierno, el 8 de mayo.

Todos los diarios, menos El Universal, agregan una lista de títulos de otras noticias en una de las columnas.

Algunos diarios también especifican los enlaces a noticias de última hora: El Comercio (Ecuador), El Nacional, El Nuevo Día, El País (Es), El Tiempo, El Universal, La Nación (Argentina) y La Nación (Costa Rica).

También ponen enlaces a noticias más vistas El Comercio (Perú), El Mundo, El Nuevo Día, Emol, El País (Es), El País (Uruguay) y El Tiempo.

Algunos diarios agregan viñetas ilustradas con enlaces a otras noticias, secciones o tipos de información: El Comercio (Perú), El Nacional, El País (Uruguay), La Nación (Argentina) y O Globo. (Ver ejemplo en Ilustración 13). 


\section{Ilustración 13. Viñetas interiores (El País, Uruguay)}

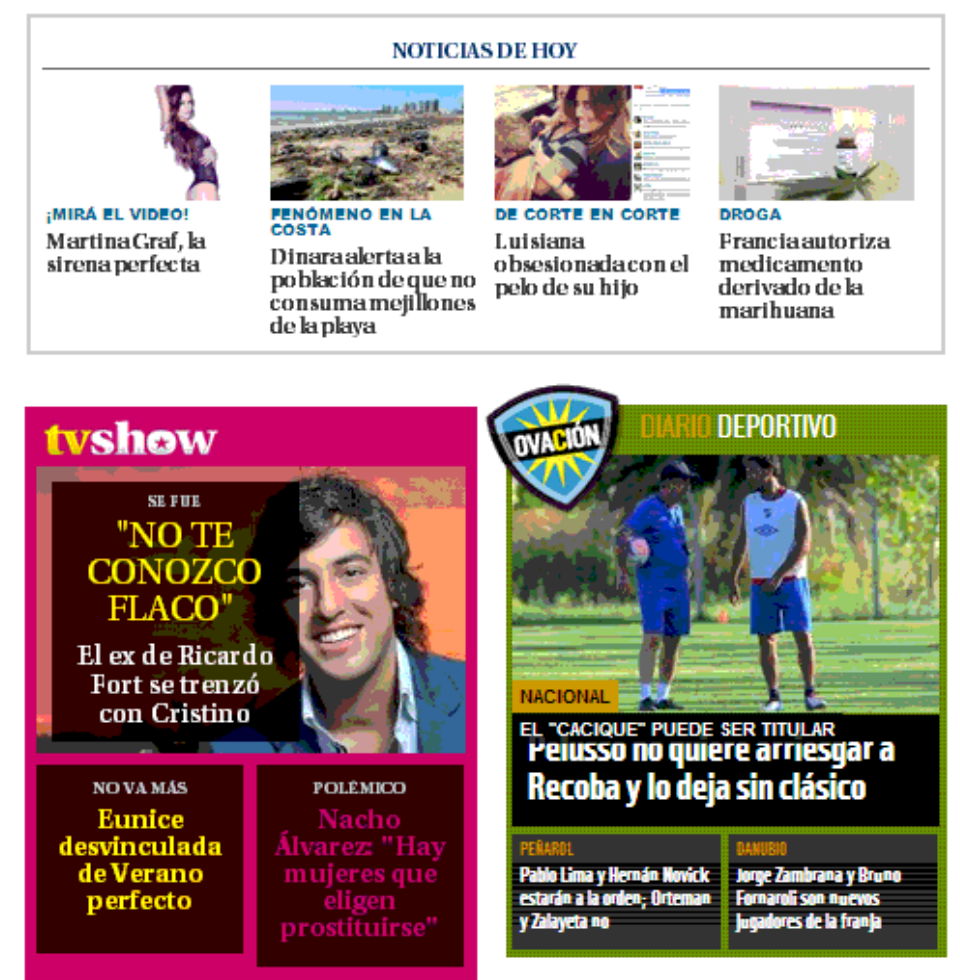

\section{Comentarios}

Casi todos ofrecen a los lectores la posibilidad de comentar la noticia. Las excepciones son El Comercio (Ecuador) y El Nacional.

\subsection{Crítica}

Antes de sacar algunas conclusiones acerca de lo observado, nos parece conveniente considerar los datos obtenidos desde la perspectiva del diseño web. El caso de las portadas, en particular, llamaría la atención de cualquier experto en diseño de interfaces web por su escasa atención a las principales reglas (en general).

\subsection{1. "Tienes 15 segundos"}

La primera regla es que la primera pantalla que aparece al abrir un sitio web debe no solo identificar claramente el sitio y su objetivo (lo cual se cumple) sino que debe permitir al receptor descubrir si encontrará en ella lo que está buscando. Para ello, las investigaciones señalan que se dispone de no más de unos quince segundos:

". El usuario escribe la dirección que intenta visitar o sigue un enlace de otra página web y espera 5 segundos a que el sitio que lo recibe muestre alguna 
reacción. Lo habitual que se espera en este caso es que el espacio que se abre muestre en la barra superior del browser el título del sitio o del contenido y que comience a aparecer algún elemento de diseño y los primeros contenidos. Si el sitio no reacciona en este tiempo, el usuario probablemente abandonará el sitio y no esperará a ver qué está pasando.

- En los siguientes 5 segundos, el usuario desea estar leyendo los titulares principales o bien el propio contenido, y tomar la decisión de seguir alguno de los contenidos. Si dichos titulares o contenidos no aparecen, el usuario asumirá que el sitio no está funcionando adecuadamente, por lo que la espera será innecesaria y utilizará mejor su tiempo en otro lado; por lo tanto abandonará el sitio web.

- En los "últimos" 5 segundos, el usuario toma una decisión radical que es la de efectuar una acción concreta (leer, seguir un enlace del nuevo sitio, bajar un documento, imprimir) o bien volver atrás o dirigirse a un buscador para seguir tras los contenidos que en ese momento le interesan. Naturalmente si el sitio no ofrece acciones adecuadas mediante verbos que inviten a realizarlas, el usuario no verá elementos de interés y lo abandonará.” (Camus, J.C., p.62)

Camus detalla en el siguiente gráfico la relación directa entre el despliegue de los contenidos y el interés del usuario:

Ilustración 14. Despliegue de los contenidos vs. Interés del receptor

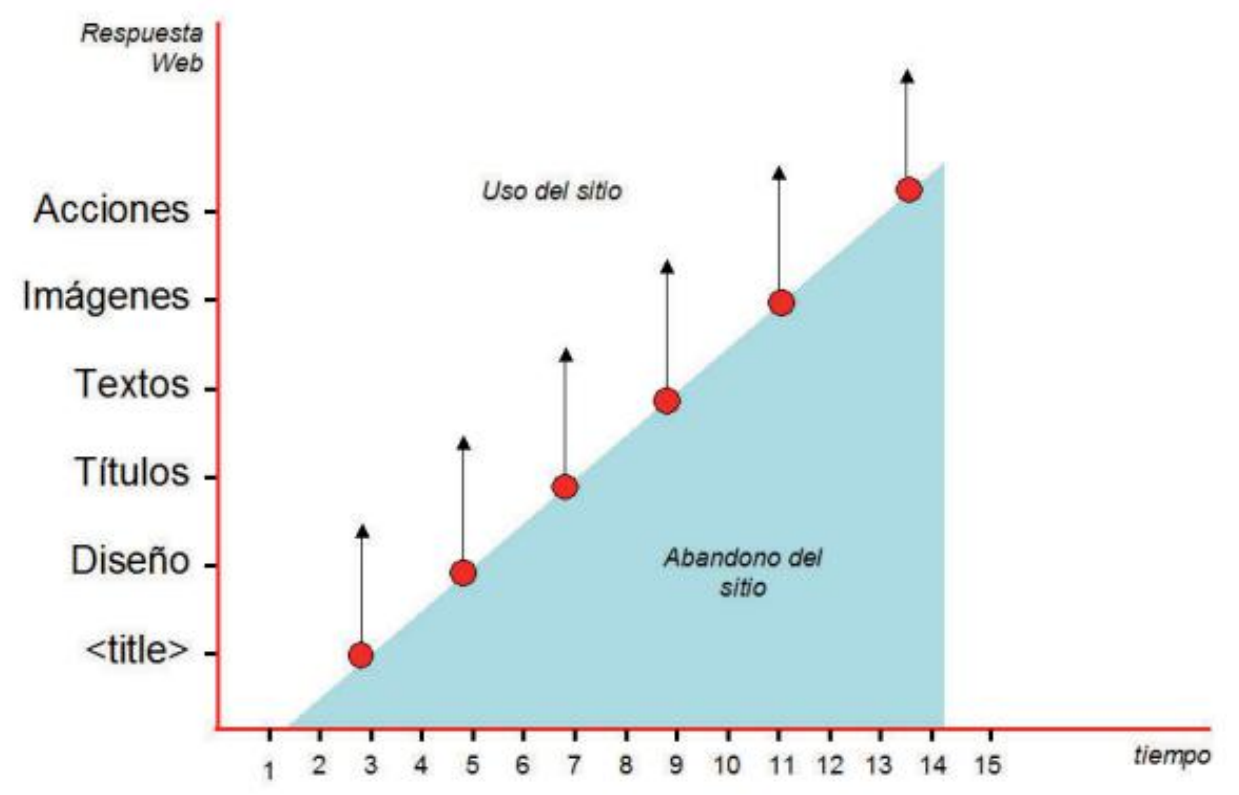

La segunda fracción de 5 segundos es a la que los editores deben prestar la mayor atención y corresponde a la primera pantalla que verá el lector: su contenido es clave y debe encontrar ahí todo lo necesario para decidir si sigue leyendo o navegando. 


\subsubsection{Cabecera}

La cabecera es la "zona de contexto" de la página web, donde están los espacios esenciales de identificación y navegación. Es la más importante para los primeros cinco segundos. En el caso de los periódicos visitados, la descarga de la cabecera se ha cumplido adecuadamente, salvo cuando tratamos de ver el nuevo diseño de El Comercio de Perú el día que cambió pero, como hemos señalado, se solucionó en los días siguientes. Obviamente la descarga puede depender de la velocidad de las redes entre la fuente y el lugar donde se encuentra el receptor. En el caso de periódicos, la presencia de la fecha y hora es otro elemento clave en esta primera etapa, ya que el lector querrá saber si tendrá acceso a las últimas noticias. El Tiempo y El Comercio de Perú solo colocan la fecha en su cabecera y El Tiempo la coloca debajo de su nombre, algo menos visible. Mencionar la hora, por otra parte, sin mencionar si es o no la hora de la última actualización no es tampoco definitorio en esta materia por cuanto los programas informáticos indican con facilidad la fecha y la hora de transmisión en forma automática. Por lo tanto, señalar "actualizado a las ...", como hace El Mundo debería ser la regla y es un error hacer necesario el scrolling para saber que están incluídas las noticias de última hora, como hace El Comercio de Perú o colocarlo junto a la primera noticia, en el cuerpo de la página (en letras bastante pequeñas), como hace El Tiempo. También sería conveniente, para los diarios que ponen en portada una sección de "Última hora" o "Último minuto", que ésta aparezca en la primera pantalla vista y no mucho más abajo, como ocurre algunas veces.

La cabecera contiene además una indispensable "zona de acción", que es la que ha de permitir -inmediatamente- al receptor acceder a las opciones de navegación para pasar a la sección que más le interesa, especialmente si no le interesan -o ya ha visto- las noticias de portada. Para ello se recurren a las barras de menú que, como hemos visto, pueden tener diversas posiciones. También debe estar disponible el acceso reservado a los lectores suscritos. Aquí se comete en todos los casos un importante error: deberían aparecer los recuadros para ingresar la identificación (login) y la contraseña en lugar del botón que obliga a abrir otra página en que éstos se muestran para luego redireccionar a la página de acceso reservado: un paso intermedio innecesario que cualquier manual de diseño web recomienda evitar (lo que apenas requiere un espacio ligeramente mayor).

Algunos, como El Nuevo Día, sugieren ingresar con la identificación de una cuenta de Facebook, un sistema llamado "login social" que se está generalizando debido a su facilidad para registrarse, pero solo para quienes tienen una cuenta en dicha red social. Los demás, sin embargo, pueden registrarse con su e-mail. La facilidad que representa el login social, sin embargo, está acompañada de una transferencia de información: la red social es informada de la visita y, de este modo, puede saber qué página visita el lector, cómo lo hace, cuándo lo hace y qué ve, con el fin de ofrecerle publicidad personalizada. El diario, por su parte, puede obtener un mayor conocimiento de sus 
suscriptores. ¿Será también una forma complementaria, para el diario, de obtener remuneración por publicidad? Creemos que es delicado recurrir a este sistema porque su base es la consideración del lector más como producto (comercializable) que como cliente o "valioso receptor" de información. Aunque abundan los sitios que utilizan el login social, algunas empresas han preferido abandonarlo después de un período de prueba, generalmente porque no desean que su lista de clientes dependa de un tercero (que tiene sus propios objetivos comerciales). Está claro que quienes son recelosos de su privacidad no aceptarán utilizar este sistema y el diario que lo utilice no podrá captar a este lector. Según señala el centro de investigación PewResearch, los lectores que visitan las páginas web de medios de comunicación entrando desde un motor de búsqueda $\mathrm{o}$ desde Facebook gastan tres veces menos tiempo en el portal informativo que los que ingresan directamente y leen solo unas 4 páginas contra unas 25 (Mitchell \& col.).

\subsubsection{Barras de navegación}

En materia de barras de navegación, todos los diarios tienen una barra debajo de su nombre y la mitad tiene otra por otra encima. Sin embargo, no existe unanimidad en la fórmula utilizada: 7 diarios solo colocan enlaces en la barra inferior mientras 4 ofrecen menús desplegables (En la barra superior, si la hay, siempre son enlaces).

El menú desplegable (Ilustración 15) es el formato estándar para las barras horizontales y se esperaría que todos los diarios la usen ya que es la forma de facilitar el acceso más rápido a contenidos específicos.

Ilustración 15. Menú desplegado en La Nación (.ar)

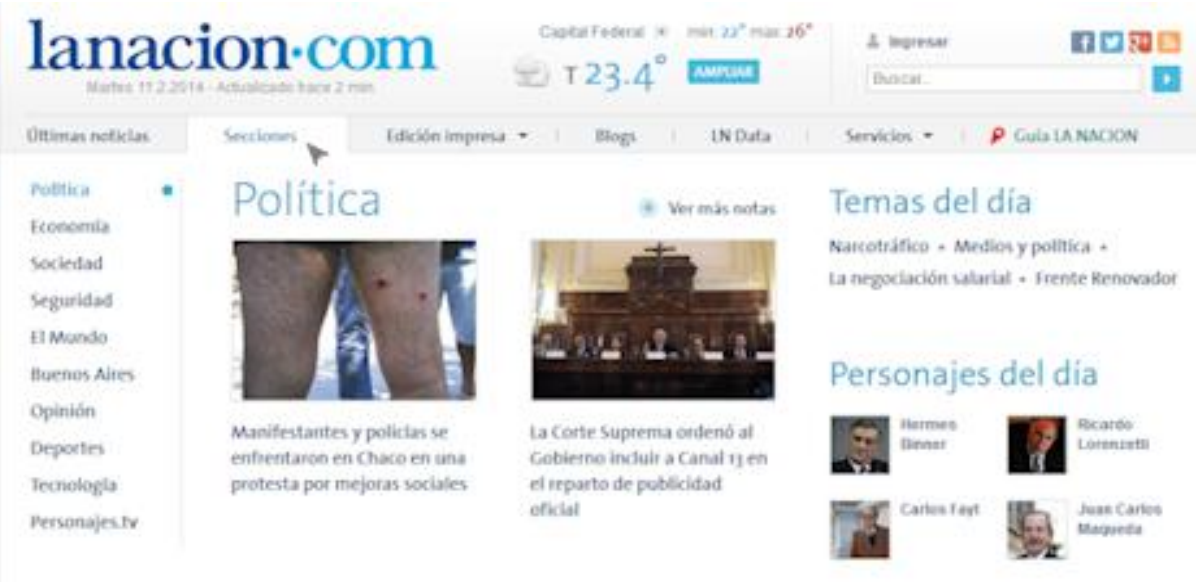

El Universal utiliza un sistema diferente: al pinchar sobre el indicador de la primera barra, cambia el contenido de la siguiente, donde solo hay enlaces (Ilustración 16). 


\subsubsection{Publicidad destacada}

Incluir publicidad en la cabecera o en la parte superior del cuerpo, para que aparezca en la primera pantalla, puede tener una justificación financiera, evidentemente importante para medios digitales, pero es obvio que no responde al interés del lector, además de ralentizar también la descarga. De considerarse indispensable, colocarla fuera del marco normal, como lo hace La Nación (Ilustración 1), parece ser una opción más válida que dentro de la cabecera o por sobre la identificación propia como hacen varios otros medios. En el caso de El Universal encontramos ambos sistema (Ilustración 16), con el agravante de que el aviso de "descubrimiento de software espía" -que se nos apareció varias veces- es totalmente falso y resulta ser una trampa para que el receptor se inquiete y visualice un archivo flash relacionado con un software de seguridad que no necesita si ya tiene este tipo de aplicación y lo mantiene al día (como debería ser). Dicho aviso se turna con otros como anuncios de premios o de extensiones -falsamente- obsoletas del navegador. El Comercio de Ecuador también coloca este tipo de advertencia falsa en la parte superior de su portada. Este tipo de publicidad debe, a nuestro juicio, ser evitado ya que es objetable desde un punto de vista ético.

Ilustración 16. Publicidad destacada (y tramposa)

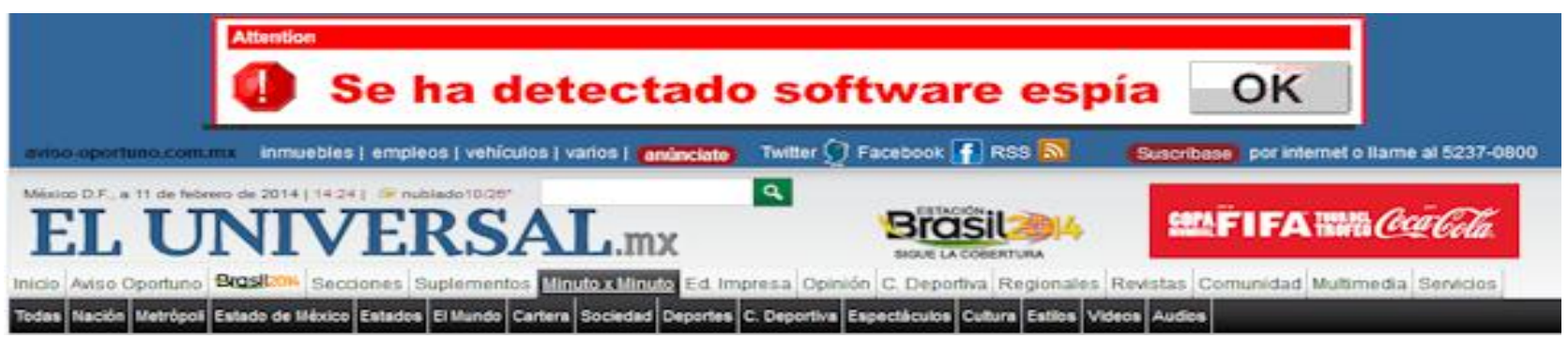

Otra alternativa que empezaron a usar algunos periódicos y revistas ha sido la de colocar un aviso en la página de acceso, que obliga a dar un paso más para llegar a su portada. Lo vimos el día 11 de febrero en El Universal (Ilustración 17) donde, aunque parezca de carácter noticioso, es una invitación a contratar publicidad para este espacio. Como ya lo hemos señalado, todo lo que retrasa el acceso a la información que interesa al lector es desaconsejable, pero es evidente que las necesidades económicas pueden ser perentorias.

Recomendaríamos a los encargados revisar los estudios sobre la publicidad en internet. Estudios de los últimos años muestran que menos del $0,1 \%$ de los lectores prestan atención a la publicidad que encabeza una página y que requiere una atención de 20 segundos para que un aviso sea efectivo (cfr. T.Haile). La regla de los 15 segundos obliga a concluir que es poco adecuado colocar este tipo de "distractor" en la primera pantalla: el lector lo "saltará", buscando lo que quiere. Por el contrario, colocar avisos 
más abajo en la página les da más posibilidad de atraer la atención, aunque no es conveniente interrumpir con ellos el flujo de noticias (Una solución es una columane reservada, como podemos ver en El Mundo, Ilustración 18).

Ilustración 17. Portada publicitaria

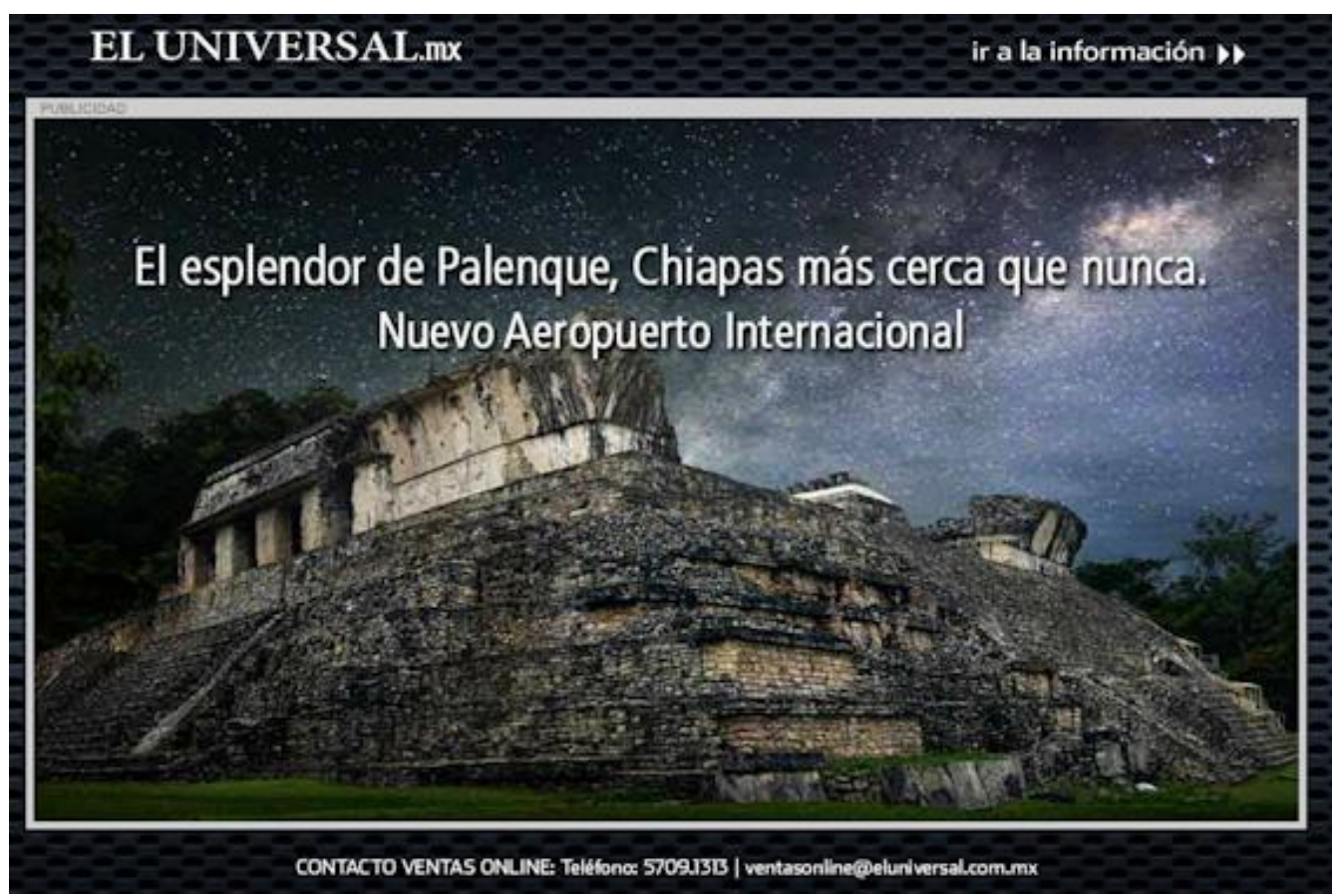

Ilustración 18. Columna publicitaria (El Mundo)

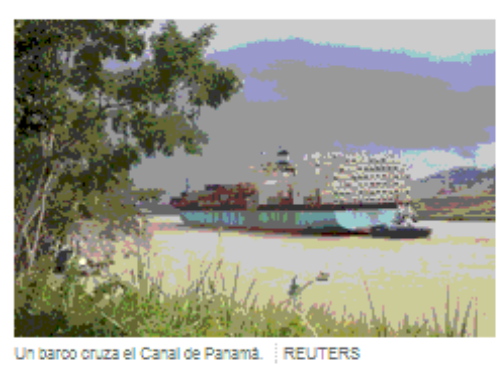

Panamá amenaza a Sacyr y dice no tener reparo en acudir a 'otro contratista' 32

'Si se quieren ir que se vayan. El Canal es nuestro y no nos van a chantajear', ha dicho un diputado. El Canal asegura tener ya sustitutos en mente.

El Tesoro coloca $\mathbf{5 . 2 8 8}$ millones con los intereses

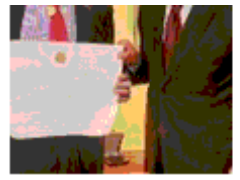

1814, el año de las tres restauraciones

PEDPO J. RAMIREZ

Discurso pronunciado por el director de EL MUNDO tras recibir la condecoración de la Orden Bernardo O'Higgins de Chile.

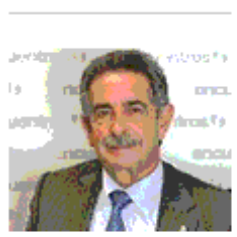

ENCUENTROS Revilla:
LFP World Challenge, clubes y empresas por la 'Marca España'

0

Presentado en el CSD el proyecto LFP World Challenge para 'superar la crisis y crear Marca España' a través del fúthol español con giras por varios paises como China, EEUU, México...

'No es ninguna catástrofe jugar el Mundial en invierno'

Javier Tebas, presidente de la LFP, no es Javier Tebas, presidente de la LFP, no es
contrario a disputar el Mundial de 2022 en invierno: 'Solo es necesaria una buena planificación para que sea un éxito'.

La eterna confusión en torno a Qatar

\section{De tiendas}

Hucha digital clasificadora

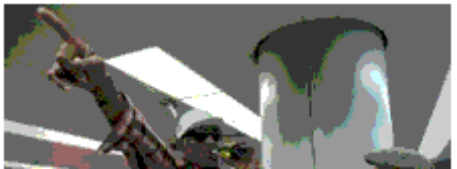

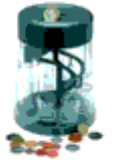

Reloj Munich MU-123$41.3 €$

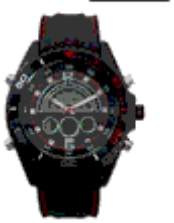




\subsubsection{Zona de información (cuerpo noticioso)}

La posibilidad de leer de inmediato los titulares principales presenta problemas más críticos aún que la cabecera. Puede parecer atractivo para el medio colocar múltiples fotos en la parte superior del cuerpo (Ej. Ilustración 5), pero ésto tiene una doble desventaja: hace más lenta la descarga de la portada y los títulos o pies de foto correspondientes podrían resultar menos legibles en pantallas pequeñas. La mayoría de los diarios, sin embargo, prefiere ilustrar su principal noticia del momento y agregar otras sin ilustración o con una mucho menor (Ej. Ilustración 9).

El mayor problema, sin embargo, es la extensión de la página de inicio. Como hemos mencionado, puede llegar al equivalente a 13 veces nuestra pantalla grande (bastante más si se cuenta con una pantalla inferior), lo cual es evidentemente exagerado. Los diarios optan generalmente por anunciar más noticias y otros artículos en su portada digital que en su portada impresa, lo cual parece correcto para facilitar la "navegación" del lector. Pero, según las reglas tradicionales del diseño web, se debe evitar que una página se extienda por más de 4 pantallas (especialmente cuando contiene muchos enlaces). Solo uno de los diarios respeta esta regla (El Nuevo Día) y 4 ocupan 10 o más pantallas, el promedio siendo de 8,46 en nuestro caso. Sugerimos a los que superan las 5 pantallas revisar su diseño y, a todos, asegurarse de que las noticias del día estén recogidas en las 2 a 4 primeras pantallas.

Ésto es aún más crítico para la recepción en móviles. Como hemos mencionado, la mayor parte de los diarios presentan la misma versión web en PC y equipos móviles, confiando en el ajuste realizado por el navegador, lo cual no es lo más adecuado. Lo mínimo es ofrecer una versión especial para móviles que reconozca el tipo de equipo y se despliegue automáticamente en éstos, como hacen El Comercio (Ec), Emol, La Nación (CR) y El Nuevo Día. Es correcto, pero no lleva necesariamente al mejor despliegue. El más adecuado es el que ofrece El Mundo en su versión móvil (Ilustración 19), la que evita la multiplicidad de columnas -sin necesidad de una app especial- lo cual facilita enormemente la lectura, pero ésta no aparece en forma automática y se ha de escoger en la barra de menú. O Globo y El Nuevo Día ofrecen una app propia para los móviles, pero los expertos consideran que es preferible evitar este tipo de recurso. La programación HTML con JavaScript permite perfectamente hacer que el navegador recoja y ofrezca la versión más adecuada para la pantalla del lector. 


\section{Ilustración 19. "El Mundo” móvil}

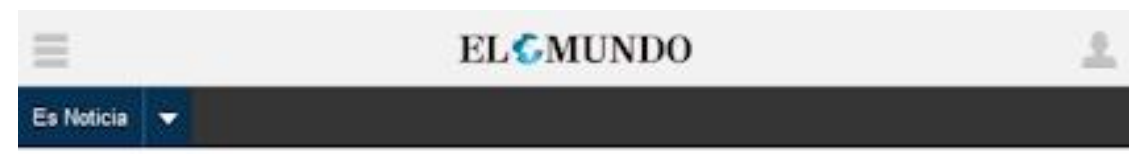

Portada

Panamá anuncia un 'principio de acuerdo' con

Sacyr sobre el Canal

La Autoridad del Canal de Panama dice que se han cerrado "varios temas" y hay un 'principio de acuerdo". Pero advierte de que "aún quedan algunos puntos por resolver" y que las partes estain "trabajando en esa dirección". Aùn asi parece claro que Sacyr acabará la obra

- 'Abierto en canai (de Panama)', por John Multer

a 'Estamos perdiendo un tempo de oro en las obras des Canar'

\section{Alaya investiga a Diego Valderas y al presidente de la Diputación de Sevilla}

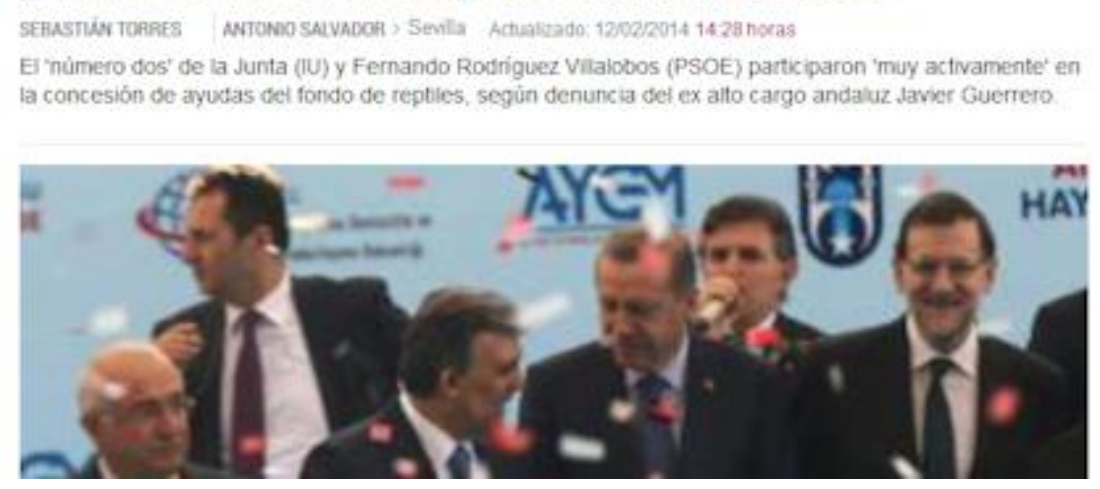

Otro error -a nuestro juicio- es la mezcla de noticias del día con accesos a otras secciones, publicidad, etc., que conspira en contra del principio de facilitación del acceso a lo más urgente o interesante para el lector habitual. Este desorden, que observamos en algunos diarios al avanzar con el scrolling, puede además confundir al lector o llevarlo a suspender su avance en el recorrido visual de la portada. Una clara separación entre noticias, accesos a suplementos o canales complementarios, publicidad, etc., sin duda facilitaría la lectura y daría cuenta de un diseño más esmerado y preocupado por el lector, conforme a los principios del correcto "user interface design" (cfr. Krug, Nielsen, Weinschenk, etc.). S.Krug resume sus recomendaciones escogiendo un sitio notioso "modelo de eficiencia" (Ilustración 20, de Krug p.185). Hemos administrado durante años un sitio web de noticias tecnológicas tratando de ceñirnos a las mismas reglas (Ilustración 21). 


\section{Ilustración 20. "Portada eficiente" según Krug}

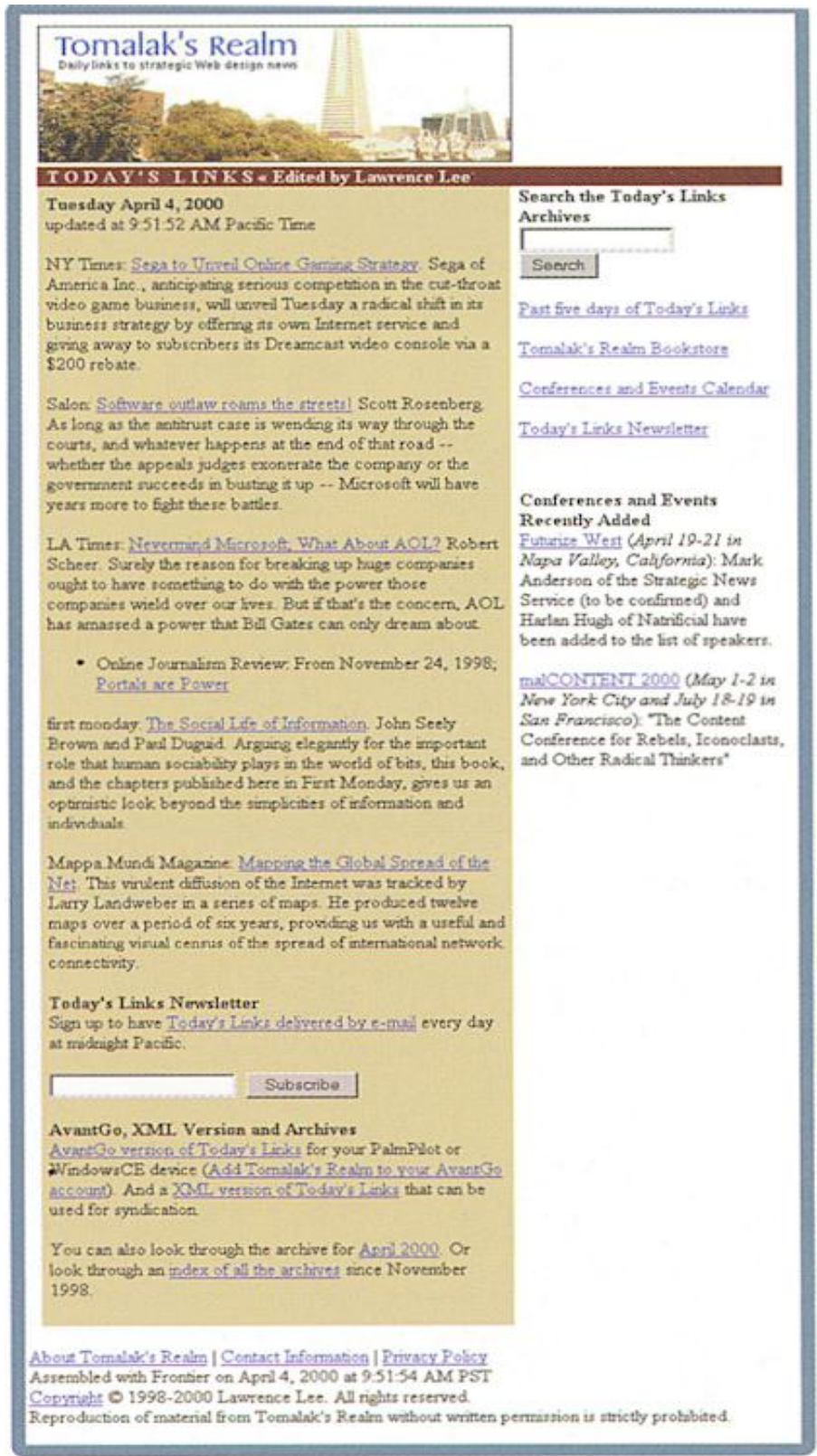

(El sitio mencionado ya no existe) 
Ilustración 21. Nuestro modelo

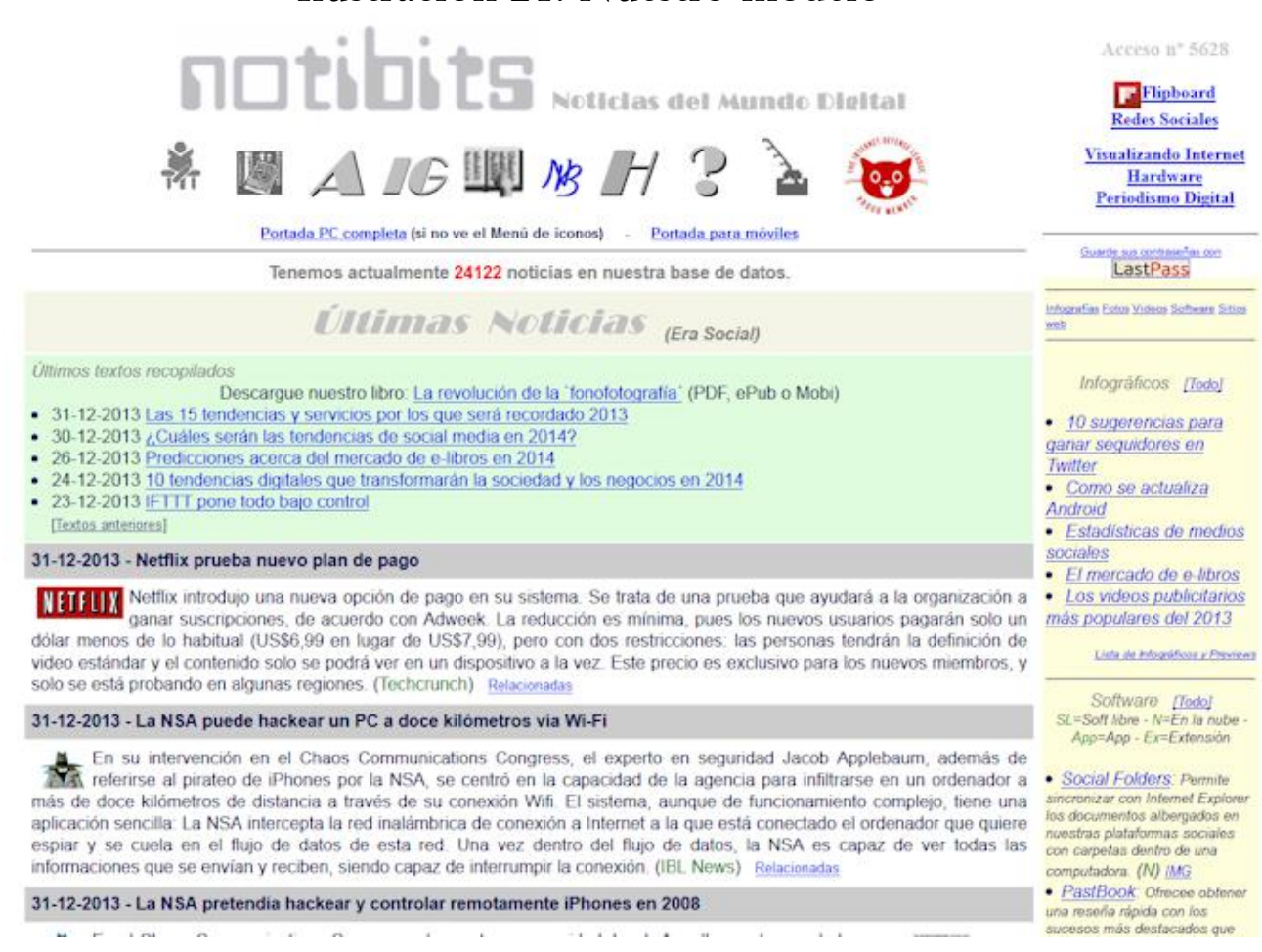

\subsubsection{Página interior}

Las páginas consagradas a cada noticia, felizmente, se ajustan generalmente mejor a las reglas básicas y también a las reglas complementarias a tener en cuenta en el caso de páginas "interiores", es decir diferentes de la página de inicio (home page), reglas que J.C. Camus resume como sigue:

"Es necesario considerar que cualquier pantalla debe estar preparada para recibir la visita de un usuario, ya que no necesariamente accederán al sitio web comenzando por la página de inicio. Ello debido a la importancia creciente de los buscadores que indexan toda su información y ofrecen acceso directo a cualquier contenido del mismo. Debido a esta realidad, es necesario que todas las pantallas ofrezcan al usuario lo necesario para entender el sitio web que visita, en particular ofreciendo cuatro zonas de datos que ayuden en diferentes ámbitos a las acciones de contextualizar, informar, promover e interactuar para ayudar a cumplir la estrategia que se haya definido.” (Camus, p.70)

Estas página reproducen la identificación del medio, indican la sección y tienen barra de navegación, aunque no siempre idéntica a la portada (lo cual debería ser ponderado). El título del artículo es algunas veces diferente, pero en el sentido de ser menos "sintético" que el presentado en la portada. Hay también una mayor economía de columnas, lo cual facilita la lectura, salvo quizás en la inserción desordenada de fotos que hace La Nación de Costa Rica (Ilustración 10). 
Dado que los lectores pueden llegar a estas páginas mediante enlaces que pueden ser otros que los de la portada, es útil colocar aquí enlaces a noticias de última hora. Algo más dudosa, en cambio, es la utilidad de incluir en este tipo de página la lista de las "más vistas". Pero lo más importante es sin duda agregar enlaces a información complementaria (noticias anteriores sobre el mismo tema, o relativas a instituciones o personas mencionadas, etc.). Es aquí donde reside la "ventaja comparada" y el "valor agregado" de los periódicos digitales: en la puesta en valor -y utilización- de su sistema de documentación (ver Colle, R. 2009 e Ilustración 22). Sin embargo, solo 5 diarios utilizan para ello "etiquetas" temáticas y 6 ponen enlaces dentro del texto de la nota.

Ilustración 22. El valor de la noticia ${ }^{3}$

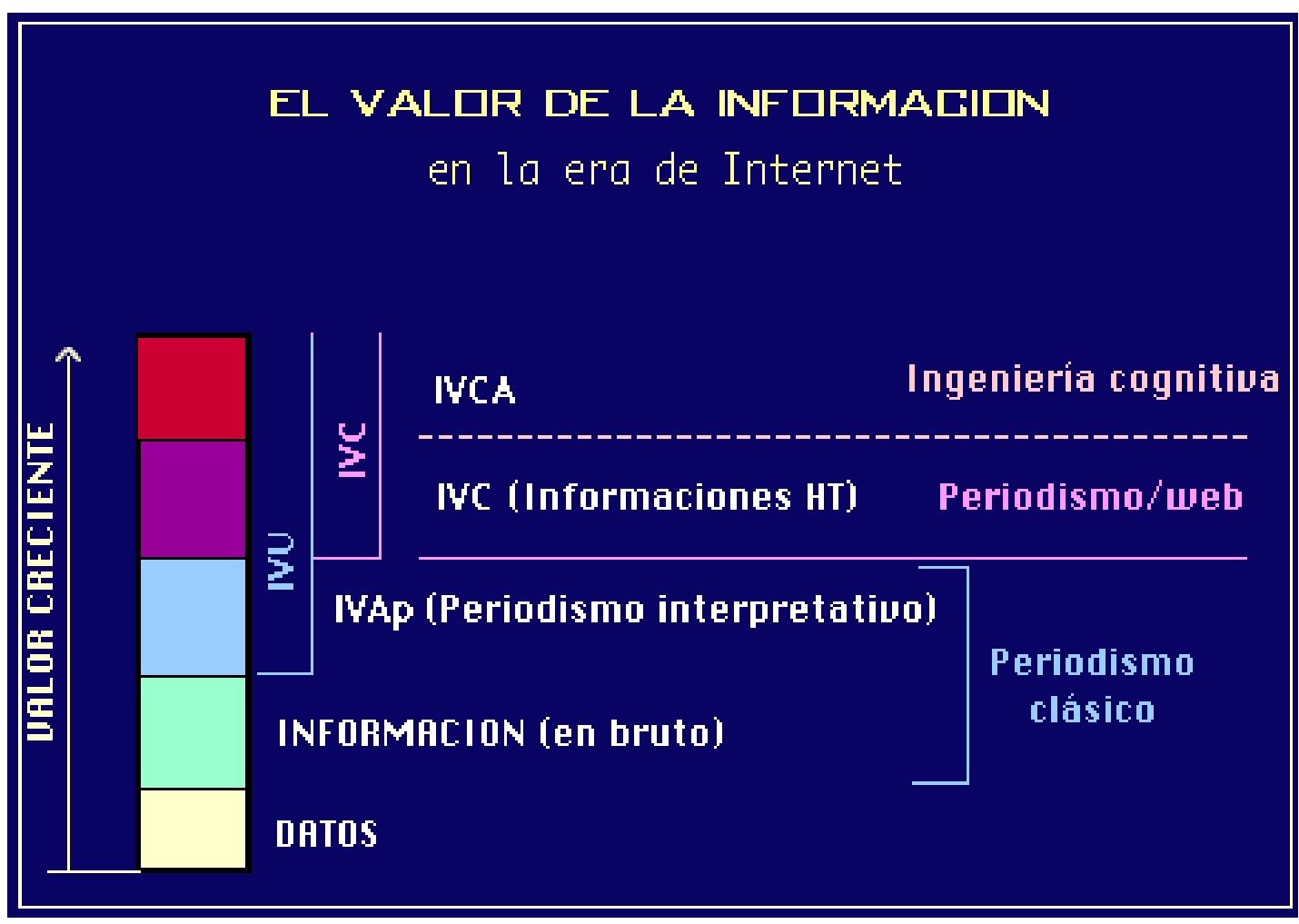

La Información con Valor de Uso (IVU) tiene tres niveles:

IVAp: Información con valor agregado por el periodista experto.

IVC: Información con valor cognitivo, es decir información inicial más informaciones complementarias (obtenidas a través de los hipervínculos), unidas a los conocimientos previos del usuario.

IVCA: IVC ampliada gracias a la ingeniería cognitiva, cosa que, por ahora, sigue sin estar al alcance de los medios periodísticos pero no tardará a dominar (Hacia ahí se encaminan los sistemas de análisis de "big data").

Es interesante ver que los diarios se han preocupado de su presencia en las redes sociales (lo cual merece un estudio específico) y que varios han abierto un espacio para que los lectores comenten las noticias, pero la mera publicación (automatizada) de los comentarios no es la mejor manera de transformarlos en participantes ("prosumidores"

3 Conceptos introducidos por el prof. Mario Boada en sus clases sobre periodismo en Internet (Escuela de Periodismo, Pontificia Universidad Católica de Chile). 
- consumidores-productores, en términos de A.Toffler - a lo cual aspira la internet). La empresa periodística ya no puede considerarse como un simple "medio de difusión": ha de transformarse en un verdadero medio de comunicación (bi-direccional), lo cual puede obligar a contar con un equipo de periodistas (bajo la dirección de un nuevo tipo de editor, el "administrador social") con una función nueva: atender las redes sociales y la información de retorno (que llegará por estas redes, por los formularios web de comentarios o vía e-mail). Esta nueva tarea implica analizar el contenido de los mensajes, determinar las acciones a realizar en cada caso, determinar la vía y el modo de respuesta (individual o por el hiperinformativo en web), etc. (Mucho está aún por idear). Todo lo cual puede generar nuevos tipos de contenidos (síntesis de los comentarios de los lectores, encuestas permanentes, etc.). Aunque debemos admitir que la realidad económica puede ser un serio impedimento, es indispensable que los medios tengan a la vista esta realidad.

\subsection{3. ¿Recopilar (y analizar) big data o little data?}

Con lo observado es difícil saber lo que hacen estos diarios con los datos que obtienen de las visitas a su web (pueden, si lo desean, conocer el lugar de residencia del lector, el equipo utilizado, el navegador y algunas otras cosas) y con los datos de quienes se suscriben. Sí pudimos observar -sin saber si es generalizado- que la suscripción gratuita puede ser requerida para escribir comentarios y ver algunas secciones o suplementos. Los datos así recogidos acerca de los lectores -junto, también, con los obtenidos en las redes sociales asociadas- se acumulan conformando los "big data". Algunos diarios, como el británico Daily Mail, revisan constantemente estos datos y los analizan para optimizar la experiencia del lector. Aprender de la conducta y de los intereses de los lectores es indispensable no solo para sobrevivir, sino ganar en la red. Hoy se requiere tanto agilidad para recoger y transmitir la noticias, como agilidad en detectar y adaptarse a las cambiantes conductas de los destinatarios (Colle, 2013).

La sola información acerca de las noticias más leídas, que varios diarios recogen, permite rediseñar con facilidad una portada de modo que satisfaga mejor a los lectores. NewsWhip hizo un experimento reuniendo las primeras planas de los principales periódicos de varios países de lengua inglesa. Luego utilizaron la aplicación Spike para revisar las historias más leídas de cada uno y rediseñaron la portada de acuerdo a los resultados, dando a la historia más compartida el lugar principal. La ilustración 23 muestra el cambio en uno de los casos considerados. Aunque trabajaron con las portadas impresas, el principio es el mismo para las digitales. 
Ilustración 23. Portada rediseñada según frecuencia de lectura
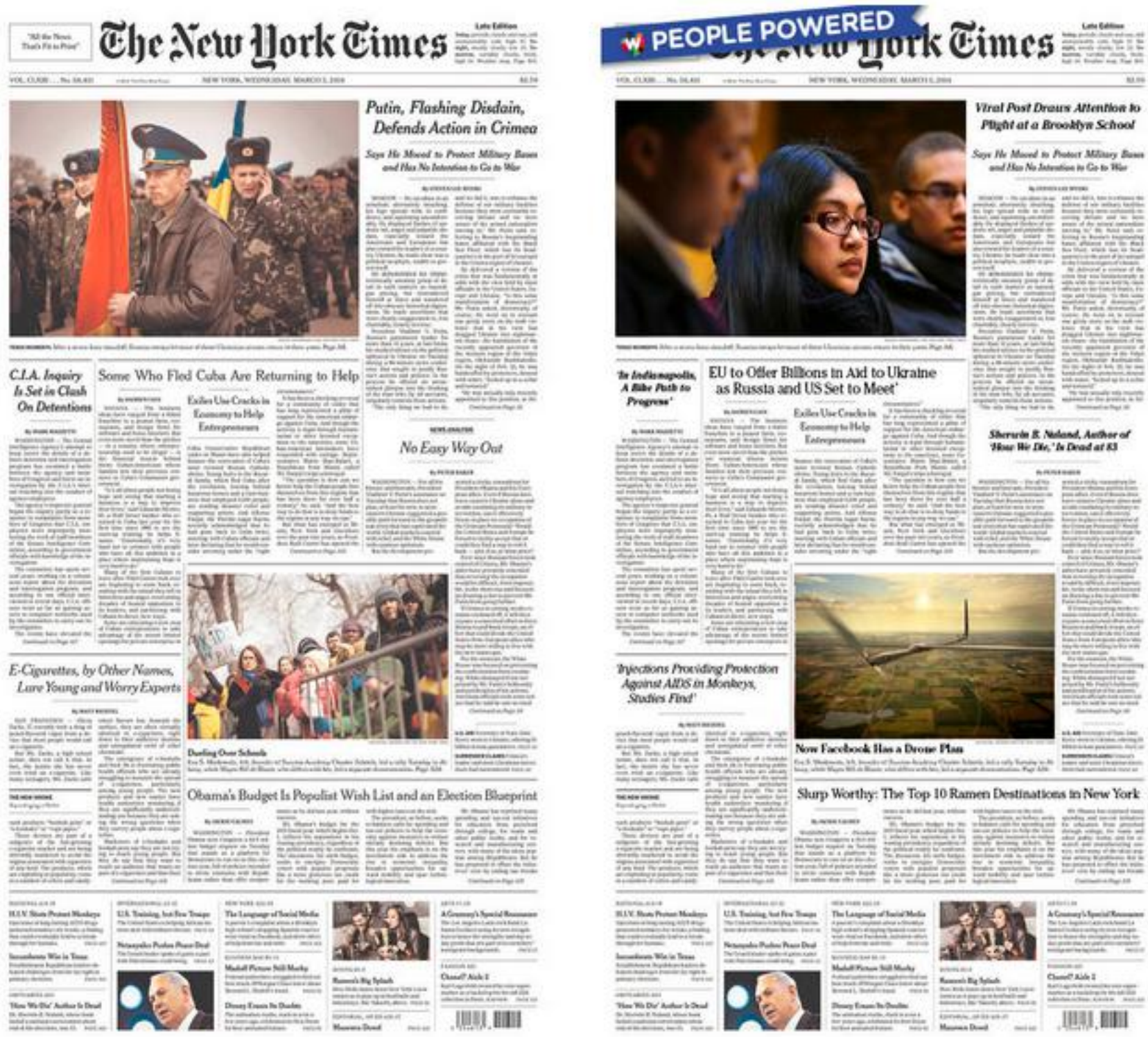

Fuente: http://blog.newswhip.com/index.php/2014/03/people-powered-front-pages-rock

Pero si de relacionarse mejor con los suscriptores se trata, es conveniente considerar y adecuar el tratamiento de los "Iittle data", es decir de los datos específicos de cada suscriptor. Jeff Jarvis, periodista americano que fue el director fundador de la revista Entertainment Weekly, opinaba que los nuevos medios debían medir lo que hacen sus usuarios para darles servicios de forma personalizada (Arriagada, 2014a). Analizando los "little data", se puede hacer fácilmente un periódico ajustado a los deseos de cada lector. Bastaría que el suscriptor registrase sus intereses (p.ej. bajo la forma de un conjunto de descriptores) para ofrecerle -sin mayor dificultad- una portada personalizada con los titulares de las noticias de su interés, eventualmente al lado o antes de los titulares destacados del día seleccionados por el propio diario. Es incluso posible registrar tales intereses sin preguntar nada, anotando simplemente los descriptores de las noticias que lee y su frecuencia. Según Marcos Weskamp, diseñador 
responsable de la experiencia de Flipboard, "la aplicación ideal pasa por desarrollar el diseño para textos paginados y el algoritmo encargado de aprender sobre lo que el lector leía" (Arriagada, 2014b). Lo tienen claro en Twitter, que utiliza este tipo de algoritmo -aunque global y no por lector- para definir sus trendings topics, y varios medios norteamericanos, como señala Kelly McBride, de Poynter: "Las empresas periodísticas están apostando por estos algoritmos, ya que estos tienen un efecto sobre la economía de los medios" (S.Pichihua, 2014).

En la base de datos basta para ello asociar a la table de suscriptores una tabla con los descriptores que le interesan -sean elegidos por él, sea determinada a partir de sus lecturas más frecuentes- y conectarlas a la base de datos de noticias a través de una tabla de descriptores de éstas (ver detalles en Colle, 2009, p.13). En la ilustración 24 mostramos los cambios que con ello se producen en el proceso informativo principalmente desde el punto de vista del lector. Las flechas rojas muestran el beneficio de eficiencia en la lectura. En la conexión, se mantiene la posibilidad de acceder a otros contenidos para "vitrinear", si el lector lo desea (vía enlace a portada común o menús comunes).

Ilustración 24. Opciones del lector en sistema personalizado

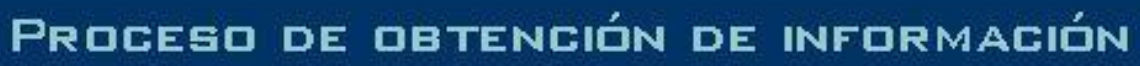

\section{\begin{tabular}{l|l} 
Proceso genérico & Lectura de hiperinformativo
\end{tabular}}

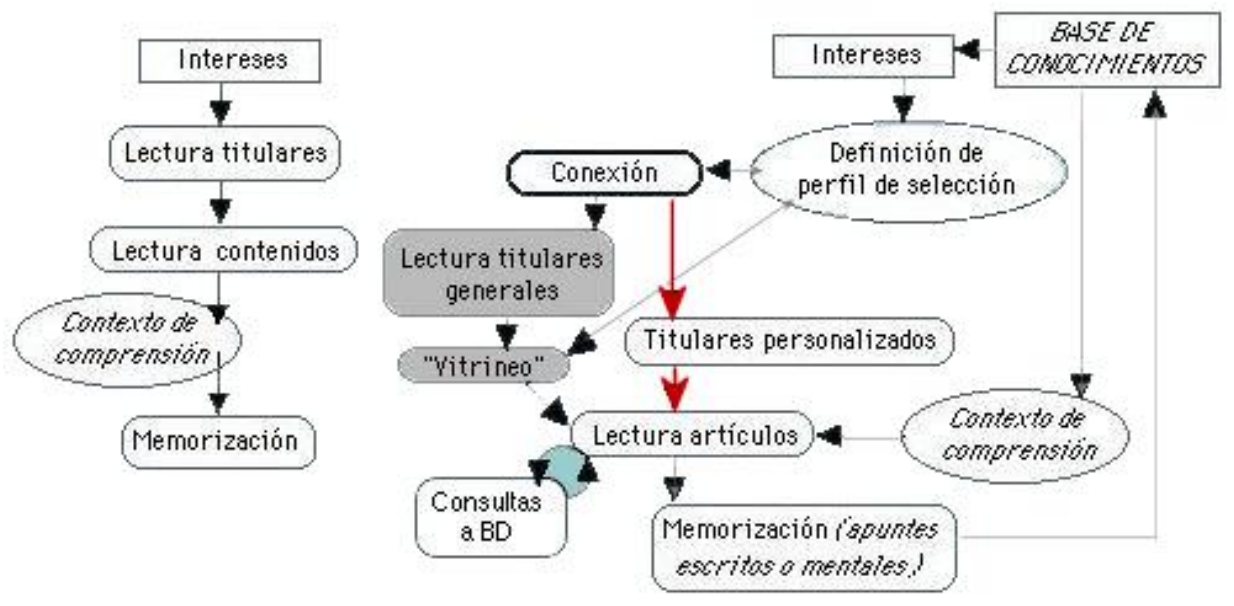

\subsection{Conclusión}

A veinte años de la aparición del primer diario digital iberoamericano ("Hoy on line", en Ecuador), hemos de reconocer que Iberoamérica siguió rápidamente la senda abierta por el Chicago Tribune (1992) y esto en el mismo momento en que la web empezaba a popularizarse. Pero si bien se siguió la corriente en materia de programación (HTML, 
CSS, etc.), los diseñadores parecen no haber profundizado mucho el tema del diseño de interfaces de usuarios. Algunos editores parecerían incluso desconocer todavía las características de la comunicación por hipertexto, especialmente para enriquecer la información de las notas de prensa. Hemos visto que existe coincidencia en cuanto a producir en general portadas que reproducen de cerca el formato del diario impreso y algunas veces de extenderlas interminablemente, incluso para su recepción en equipos móviles, lo cual es muy poco apropiado. No se aprovecha suficientemente la posibilidad de hacer más eficiente la navegación a través de los menús desplegables, lo cual debería ser una norma absoluta y podría inspirarse de las tiendas de e-comercio que conocen muy bien las ventajas de esta modalidad de acceso. Tampoco se utilizan los recursos disponibles para ofrecer versiones más personalizadas.

\subsection{Bibiografía}

Albornoz, L.A. (2006): Los principales diarios on line en español: el empleo de recursos audiovisuales y multimedia, e hipervínculos, en Telos: Cuadernos de comunicación e innovación, n.66, págs. 23-30.

Arriagada, E. (2014a): Esa manía de cobrar por el trabajo, en El Mundo De La Tarde, descargado el 19/02/2014 de

http://elmundodelatarde.orbyt.es/web/noticia/2014/02/18/53035526e2704e7a118b456 c.html

Arriagada, E. (2014b): Flipboard, la App que hace de la lectura de noticias un verdadero placer, en El Mundo de la Tarde, descargado el 12/03/2014 de http://elmundodelatarde.orbyt.es/web/noticia/2014/03/11/531f12a622601d6a4c8b457 5.html

Bushey, R. (2014): Everyone's Making News Apps But No One Knows The Right Way To Read Them, en Business Insider, febrero 2014. Descargado el 3/01/2014 de http://www.businessinsider.com/most-news-apps-will-die-after-launch-2014-2

Campos, F. (2009): La agenda temática digital de la prensa latinoamericana, en Actas del I Congreso Internacional Latina de Comunicación Social, La Laguna, http://www.revistalatinacs.org/09/Sociedad/actas/92francisco_campos_agenda.html

Camus, J.C. (2009): Tienes 5 segundos, Santiago de Chile, Autoedición, http://www.tienes5segundos.cl (PDF, descargado el 5/11/2009).

Canavilhas, J. (2007): Webnoticia: propuesta de modelo periodístico para la WWW, Universidad de Salamanca. PDF descargable de http://www.livroslabcom.ubi.pt/pdfs/20110823-canavilhas_webnoticia_final.pdf

Carvajal, M. (2013): Estrategias de distribución del contenido periodístico en dispositivos móviles: Análisis comparativo de los principales editores de prensa 
española, en González, S. \& col.: "Hacia el Periodismo Móvil", Colección Mundo Digital n 3, Alicante, Revista Mediterránea de Comunicación, pp.33-49

Canavilhas, João (2007): Webnoticia: propuesta de modelo periodístico para la WWW, Livros LabCom. PDF descargado el 3/02/2014 de http://www.livroslabcom.ubi.pt/pdfs/20110823-canavilhas_webnoticia_final.pdf

Castellanos Díaz, Juliana (2011): De lo impreso a lo digital la migración de los periódicos impresos de América Latina a los entornos digitales, Razón y Palabra, 77, 2.

Colle, R. (2011): El Análisis de Contenido de las Comunicaciones, Cuadernos Artesanos de Latina n. 11, 12 y 13, La Laguna (Tenerife, España).

Colle, R. (2009): Construir un "hiperinformativo" con valor cognitivo, en Actas del I Congreso Internacional Latina de Comunicación Social, Universidad de La Laguna (Tenerife). http://www.revistalatinacs.org/09/Sociedad/actas/COLLE_hiperinformativo2.pdf

Delgado, A. (2009): Quince años de prensa digital en España, en Cerezo, J. \& col. "La revolución de la prensa digital", en Cuadernos de Comunicación Evoca n 1, Madrid, Evoca Comunicación e Imagen.

http://www.evocaimagen.com/cuadernos/cuadernos1.pdf (descargado el 13/02/2014).

Franco, G. (2008): Cómo escribir para la Web, Bases para la discusión y construcción de manuales de redacción 'online', Universidad de Texas en Austin, Centro Knight para Periodismo en las Américas.

González, M.: Facebook, Google, Twitter, Amazon... ¿Por qué todos quieren su propio login social?, en Genbeta, 18 de octubre de 2013, descargado ese día de http://www.genbeta.com/redes-sociales-y-comunidades/facebook-google-twitter-amazonpor-que-todos-quieren-su-propio-login-social

Haile, T. (2014): What You Think You Know About the Web Is Wrong, en Time.com 9/03/2014, descargado en 15/03/2014 de http://time.com/12933/what-you-think-youknow-about-the-web-is-wrong/

Kayser, J. (1962): Le quotidien français, País, Plon.

Krug, S. (2000): Don't make me think - A Common Sense Approach to Web Usability, Indianapolis, New Riders Publishing.

Mendiguren, T., Pérez, J.A., Peña, S. (2011): Renovarse o morir: la transformación de la prensa tradicional con presencia en internet hacia un modelo más participativo, en "La investigación en periodismo digital. Algunos trabajos desde el ámbito universitario", Zaragoza, Asociación de Periodistas de Aragón, 2011, pp.421-431.

Mitchell, A., Jurkowitz, M. \& Olmstead, K. (2014): Social, Search and Direct - Pathways to Digital New, en PewResearch Journalism Project, 13/03/2014 - Descargado el 17/03/2014 de http://www.journalism.org/2014/03/13/social-search-direct/

Moreno, A. (1998): La propuesta metodológica de Jacques Kayser, descargado el 3/02/2014 de http://www.amparomorenosarda.es/es/node/454 
Nielsen, J. (1999): Designing Web Usability: The Practice of Simplicity, Indianapolis, New Riders Publishing.

Pérez, M.J., y Romero, M. (2010): Tratamiento periodístico de la industria de la comunicación en las ediciones digitales delos principales periódicos españoles, en "El periodismo digital desde la perspectiva investigación universitaria", Actas XI Congreso de Periodismo Digital de Huesca, pp.370-383

Pereira, J. et alt. (2011): Arquitectura de la información, bases de datos y gestión de la memoria en los cibermedios. Caso de elpais.com y lavozdegalicia.e, en "La investigación en periodismo digital. algunos trabajos desde el ámbito universitario", Zaragoza, Asociación de Periodistas de Aragón, pp.234-247.

Pichihua, S. (2014): Qué tan importantes son los algoritmos para los medios, en Clases de Periodismo, 11/03/2014, leído ese día en http://www.clasesdeperiodismo.com/2014/03/11/que-tan-importantes-son-losalgoritmos-para-los-medios/

Roitberg, G. (2013): Verdades y mitos del periodismo en Internet, http://www.slideshare.net/grmadryn/verdades-y-mitos-del-periodismo-en-internet18582836

Watlington, L. (ed.) (2013): Guía de periodismo digital, Washington DC, Centro Internacional para Periodistas (ICFJ). PDF descargable de http://www.centroperiodismodigital.org/sitio/?q=content/guia-de-periodismo-en-la-eradigital

Weinschenk, S. \& col. (1997): GUI design essentials, Hoboken (NJ), Wiley Computer Publishing. 


\title{
2
}

\section{La agenda temática digital de la prensa latinoamericana}

\author{
Dr. Francisco Campos
}

Profesor del Departamento de Ciencias de la Comunicación de la Universidad de Santiago de Compostela, USC, España

francisco.campos@usc.es

Lic. Diana Rivera

Profesora de la Universidad Técnica Particular de Loja, UTPL, Ecuador derivera@utpl.edu.ec

Lic. Jenny Yaguache

Profesora de la Universidad Técnica Particular de Loja, UTPL, Ecuador jjyaguache@utpl.edu.ec

\subsection{Introducción}

La agenda es el instrumento que filtra los temas relevantes que se publican en un medio de comunicación, de acuerdo a su ideología, cultura profesional, intereses e influencias externas. Sus encuadres seleccionan y resaltan acontecimientos del ámbito social que constituyen el foco de atención de la opinión publicada. El proceso alimenta y retroalimenta la opinión pública. Las teorías de la agenda-setting y del framing son líneas de investigación en las que más se ha trabajado en los últimos años pero que aún se deben revigorizar a la luz de los análisis de las nuevas prácticas de mediación (selección y ciberparticipación) que ofrecen los medios digitales. En este contexto podemos recordar que "la prensa no tiene mucho éxito en decir a la gente qué tiene que pensar pero sí lo tiene en decir a sus lectores sobre qué tienen que pensar" (Cohen, 1963: 13, citado en Rodríguez, 2004:15).

Según el profesor e investigador puertorriqueño Eliseo R. Colón Zayas, que rememora un trabajo de Daniel Riffe en Journalism and Mass Communication Quarterly, "una de las áreas más fértiles en la investigación actual en periodismo y medios de comunicación envuelve el concepto de framing". Colón Zayas resume dos definiciones del concepto, la de Todd Gitlin (The Whole World is Watching: Mass Media in the Making and Unmaking of the New Left, Berkeley: University of California Press, 
1980), que describe los frames como principios y teorías compuestas de selección, énfasis y presentación en torno a lo que existe, a lo que pasa y a lo que es importante; y la de William Gamson y André Modigliani ("The Changing Culture in Affirmative Action” en Richard y Margaret Braungart, eds., Research in Political Sociology, Greenwich, CT. JAI Press, 1987) como línea de pensamiento que provee sentido a un grupo de eventos en pleno desarrollo (Colón Zayas, 2009).

Una vez planificada la agenda temática, los medios encuadran las noticias de modo que pueda apreciarse el contenido pertinente para sus intereses y pasan a la "espiral del silencio" (Noëlle-Neumann, 1974) a aquellas otras que consideran que no lo son. Por su parte, Tankard (1991, citado en Giménez, 2006) menciona "una idea organizadora del contenido de las noticias, que provee un contexto y sugiere de qué se trata el tema en cuestión a través de la selección, el análisis, la exclusión y la elaboración de algunos de sus aspectos concretos". Para llevar a cabo ese proceso los medios trabajan con el esquema rutinario siguiente: concepción adecuada al medio e intereses empresarialesprofesionales, planificación, espacio, titular, fotografía, contraste de fuentes, elementos de ciberparticipación y sección (territorio) a la que pertenece.

La agenda temática, en palabras de McCombs (2006), es como un "paraguas" que agrupa varias teorías y categorías. El llamado "primer nivel” preestablecido de la agenda analiza la influencia de los medios en dar relevancia a unos temas respecto a otros en la opinión pública; y el "segundo nivel" o framing responde expresamente a cómo construye el periodismo el encuadre de los temas informativos y qué efectos tiene esto en la construcción de la opinión pública.

En virtud de ello, los medios de comunicación, que filtran la realidad al seleccionar y editar contenidos, construyen la agenda temática en función de los criterios y medios disponibles. Actualmente, en esta fase de la era digital, ya son los medios electrónicos los que empiezan a abrir la agenda. Es decir, los temas que serán portada en la versión impresa, entran primeramente a través de la versión digital y, al mismo tiempo, se empiezan a alimentar y retroalimentar a través de los nuevos espacios de ciberparticipación que permiten a los usuarios la posibilidad de interacción. Las versiones o ediciones digitales de los grandes diarios impresos tradicionales ya no van por detrás en las estrategias de tematización y encuadre de las mediaciones de la actualidad.

Esta investigación registra la evolución de la estructura de la prensa digital de referencia en 19 países latinoamericanos. Se tomó como muestra las ediciones on line de las principales cabeceras periodísticas de información general, seleccionándolas por países según su volumen de circulación de ejemplares impresos en base a una única fuente homogénea: el informe anual de la Asociación Mundial de Diarios (WAN). A continuación comprobamos, con respecto a cada diario, cuáles son las ediciones (digital o impresa) que cronológicamente inician el encuadre temático de la actualidad. Y por último observamos la evolución temática, por secciones, de las noticias con mayor ciberparticipación, a partir del registro cuantitativo del número de comentarios contabilizados por la primera y la segunda noticia de un día en cada uno de los diarios 
seleccionados.

Las preguntas sobre las que basamos la indagación fueron: $1 . ¿$ La edición digital va por delante del papel en el proceso de selección temática de la actualidad o aún sigue siendo subsidiaria la versión principal del modelo impreso? 2. ¿Qué noticias y de qué temática (o sección) son las que registran mayor ciberparticipación? La investigación sigue también la evolución de la prensa digital a través de la muestra seleccionada de diarios.

Este mismo estudio se realizó en el año 2009, según los datos de liderazgo en circulación de WAN de 2008; revelando, como primer hallazgo, que seis periódicos tradicionales fueron superados en algunos casos por diarios de corte popular. Es el caso de $A$ Folha, que hace cuatro años era el diario con mayor circulación en Brasil y que hoy es reemplazo por Super Noticias; El Mercurio de Chile por diario La Cuarta; La Prensa de México por diario El Metro; y La Crítica de Panamá por diario La Prensa; Hoy de República Dominicana por Listín Diario; y en Venezuela Últimas Noticias por El Universal.

La estructura de las ediciones digitales de la prensa escrita ha evolucionado en mayor medida en los últimos años y se ha ido adaptando a las tendencias cibermediáticas, según las distintas estrategias corporativas y las áreas territoriales de accesibilidad y alfabetización digital. Actualmente los diarios dan mayor énfasis a las herramientas de la Web social (blogs, foros y participaciones) de igual manera han incorporando nuevas redes sociales (Facebook, Twitter, Flickr, Youtube, Instagram, Google+, Pinterest, etc) y el nivel de participación e interacción de la audiencia ha incrementado. La mayor parte de los diarios impresos destacan también en sus ediciones digitales los contenidos multimedia, que han incrementado notablemente en los últimos años, y el éxito de su vinculación con las redes sociales.

Los cibermedios emplean el ciberespacio para la difusión pública de informaciones periodísticas y se conciben como emisores de contenidos que tienen voluntad de mediación entre hechos y público con características técnicas más amplias que las de los medios tradicionales. Comprenden características de multimedialidad, hipermedialidad, actualización permanente, simultaneidad, interconectividad e interactividad (ciberparticipación), virtualidad, ubicuidad, deslocalización, actualización, "despaquetización" o desestructuración, gestión automatizada, afiliación de redes sociales y web semántica (Campos, 2008:148).

La hipertextualidad y la multimedialidad brindan al usuario una perspectiva más amplia de la noticiabilidad según algunos expertos. Los links y elementos audiovisuales les permiten adentrarse al cibermedio, contextualizar y profundizar sobre los hechos, para "validar" de alguna manera lo que el periodista presenta. Algunos autores y bloggers proclaman por eso la pureza del periodismo ciudadano -tesis, no obstante, discutible y matizable- y que "los ciudadanos se han podido apropiar de la información periodística a través de los medios sociales" (Varela, 2008).

Las tendencias que apunta este estudio son más moderadas e interesadas por la relación 
de las rutinas profesionales de selección de las noticias y las prácticas de interacción o ciberparticipación de los usuarios de los medios sobre las informaciones de éstos. Es decir, en cómo se reproduce y alimenta el circuito de la tematización mediática.

\subsection{Método}

La investigación desarrolla el estudio comparado de la selección temática de las primeras páginas de las ediciones digitales e impresas de 19 principales cabeceras de la prensa latinoamericana: Clarín de Argentina; Super Noticia de Brasil; El Deber de Bolivia; La Cuarta de Chile; El Tiempo de Colombia; La Nación de Costa Rica; Granma de Cuba; El Universo de Ecuador; Nuestro Diario de Guatemala; La Prensa de Honduras; El Metro de México; La Prensa de Nicaragua; La Prensa de Panamá; ABC Color de Paraguay; El Comercio de Perú; El País de Uruguay; Listín Diario de República Dominicana; La Prensa Gráfica de Salvador; y El Universal de Venezuela. El primer objetivo fue comprobar si los temas de la edición impresa marcaban el enfoque de las versiones digitales o viceversa.

\subsubsection{Estrategias e instrumentos de investigación}

La selección de las citadas cabeceras periodísticas se ha efectuado partiendo de la base de escoger las que registraban mayor circulación por país, entre los diarios de información general, según los datos de los informes anuales de WAN World Trends, 2013, con datos de 2012 y 2011. En los casos en los que el informe mundial de WWT no aporta datos, éstos proceden de los propios medios o de fuentes nacionales de los respectivos países. La mayoría de los datos de circulación proceden de fuentes nacionales o de las propias editoras.

La investigación se apoyó en dos estrategias: una muestra compuesta de seguimiento de 24 horas de actualización (para la versión digital) y el respectivo análisis de contenido sobre las ediciones virtuales e impresas. La primera estrategia tiene la finalidad de obtener información de los periodos o ciclos de actualización que efectúan los diarios digitales y comprobar cuál de las ediciones es la que da el primer paso de la agenda temática: ¿la versión impresa o la digital?

El análisis de contenido, como indicaba Krippendorff (1997: 27), "ha llegado a ser un método científico capaz de ofrecer inferencias a partir de datos esencialmente verbales, simbólicos o comunicativos. Más allá de su continuo compromiso con cuestiones psicológicas, sociológicas y políticas sustanciales, en los últimos ochenta años ha aumentado de forma exponencial el interés por el uso de esta técnica y se ha procurado establecer con criterios adecuados de validez".

A partir de ahí, se analizaron las portadas de los 19 diarios, tanto en su edición impresa como digital. Al realizar la observación también se constató el interés por las 
noticias con mayor participación, elementos gráficos, multimedia y ciberpaticipación. Se seleccionó la portada porque también en los cibermedios ésta es la página de apertura que mayor información contiene y en ella se encuentran los enlaces que le permiten al usuario ingresar a la información de otras secciones. La portada, normalmente, es la página de acceso a la edición digital. En la edición impresa la portada es el escaparate en el que se muestra la selección más relevante de la agenda temática del medio.

La recolección de datos se hizo a través de fichas de análisis traducidas a tablas de datos que permitieron sintetizar la información obtenida durante la investigación y que se describen a continuación.

- Cuadro 1. Estructura y circulación de la prensa latinoamericana en 2013. Ofrece datos básicos de propiedad, edición y circulación en 2012 y 2011 sobre cada uno de los diarios en función de sus ediciones impresas tomando como fuente el informe anual de 2013 de la Wan Wordl Trends y de información generada por las propias editoras o de fuentes nacionales de los respectivos países.

- Cuadro 2. Estructura de la prensa latinoamericana, 2009. Se presenta el informe 2009 con datos del 2008 de WAN World Trends, para establecer un marco comparativo con 2012 de las nuevas cabeceras que lideran la circulación en Latinoamérica.

- Cuadro 3. Estructura de las web de la prensa latinoamericana a marzo 2014. Recoge los datos sobre la estructura de la prensa digital: mapa web, número de entradas, número de blogs, número de foros, videoblogs o web TV, normas de accesibilidad y ranking de cada ciberpágina de acuerdo a la clasificación de Alexa.com. Este último dato no es demasiado significativo pero se ha optado por mantenerlo. Esta información estructural abre el preámbulo para identificar las páginas web de los diarios y la usabilidad de cada una.

- Cuadro 4. Ciberparticipación en la prensa latinoamericana a marzo 2014. Este cuadro recoge los datos referentes al análisis de la primera noticia de mayor participación y el número total de las más participadas en toda la versión digital a marzo 2014.

- Cuadro 5. Promedio de noticias de la edición impresa y digital de la prensa latinoamericana. La investigación recogió información completa del número de noticias, fotos y elementos de publicidad de las versiones impresas y digitales de los 19 diarios; sin embargo, para un mejor análisis se procedió a realizar una tabla promedio teniendo en cuenta que la evaluación de la edición virtual (con actualización continuada en la mayor parte de las cabeceras) fue efectuada por períodos y promediada para poderla comparar con el resultado del producto en papel. 


\subsubsection{Procedimiento de análisis}

Para el estudio de los 19 diarios, se tomó como unidad de análisis la primera noticia de cada medio, clasificándola en categorías como: sociedad, política, economía y deportes. El análisis y observación se realizó el 14 y 15 de marzo de 2014, en ambas versiones, considerando la necesidad de 24 horas compuestas para constatar su actualización. En el proceso, que se inició a las 12h00 del 14 de marzo de 2014 hasta las $12 \mathrm{~h} 00$ del siguiente día, se revisaron 126 noticias digitales y 36 impresas. En la edición impresa y digital consta un diario menos debido a que en dos medios (Nuestro Diario de Guatemala y Metro de México) no fue posible acceder a sus versiones digitales; el primero hace un volcado completo de su versión impresa a la Web; y el segundo, no cuenta con edición digital y no se pudo acceder a la versión en papel. Este análisis se recogió en un cuaderno de investigación con su hora y fecha para conocer cuántas veces la noticia más importante se mantiene, actualiza o cambia, aunque aquí no se ha reproducido por falta de espacio.

A la par, se contabilizaron durante los días 14 y 15 de marzo de 2014 la distribución de noticias por cada sección, en ambas versiones, incluyendo el número de fotos y elementos de publicidad. De esta información se realizó una tabla promedio para agilizar el proceso de análisis.

Fueron elaborados otros dos cuadros, uno sobre ciberparticipación en el que se observó la primera y segunda noticia de mayor participación, con sus respectivos contactos, además del número total de noticias participadas en la edición general. El otro cuadro presenta la estructura de los diarios con los datos relacionados de mapas web, entradas y subentradas, número de blogs, foros y videoblogs.

\subsection{Resultados}

Para establecer el marco comparativo hemos optado por incluir el informe de circulación de los diarios latinoamericanos en 2009; observando un estancamiento o leve retroceso, si nos guiamos por los datos de circulación registrados por la Asociación Mundial de Periódicos a través de sus respectivos informes anuales de World Press Trends. Esta observación no es parte del objeto de investigación pero se trae a relieve como parte de la situación de las empresas de prensa escrita en Latinoamérica.

Estos informes de la Asociación Mundial de Periódicos (World Association of Newspapers, WAN) son la fuente homogénea más integrada y fiable para establecer un marco comparativo porque nutre sus datos, principalmente, de los organismos verificadores de circulación y audiencias de cada uno de los respectivos países. No obstante, hay que advertir que dicha fuente no ofrece datos de algunos países porque no existen asociaciones de empresas periodísticas o las existentes no los han facilitado a su organización mundial. 
La suma de la circulación total de la prensa escrita latinoamericana en 2009 fue de 3.547.000 ejemplares y en 2013 desciende a 3.142 .000 ejemplares. Se puede notar también un significativo incremento de diarios digitales. Ver a continuación cuadros 1 y 2 .

Cuadro 1. Estructura de la prensa iberoamericana, 2013

\begin{tabular}{|c|c|c|c|c|c|c|c|}
\hline País & Núm diarios & $\begin{array}{ll}\text { Núm. } \\
\text { dieming }\end{array}$ & \multirow[t]{2}{*}{$\begin{array}{l}\text { Primer diario } \\
\text { en difusión }\end{array}$} & \multirow[t]{2}{*}{$\begin{array}{l}\text { Lugar de } \\
\text { edición }\end{array}$} & \multirow[t]{2}{*}{$\begin{array}{l}\text { Avio de } \\
\text { fundación }\end{array}$} & \multirow[t]{2}{*}{ Circulación } & \multirow[t]{2}{*}{$\begin{array}{l}\text { Multim } \\
\text { edia }\end{array}$} \\
\hline \multicolumn{3}{|c|}{ Seleccionar columna de tabla } & & & & & \\
\hline Argentina & 185 & 160 & Clarin & Buenos Aires & 1945 & 274.000 & $\mathrm{Si}$ \\
\hline Brasil & 727 & 139 & Super Noticia & Belo Honizonte & 2002 & 307.000 & $\mathrm{Si}$ \\
\hline Bolivia & 25 & 20 & E1 Deber & Sta. Cruz & 1953 & 35.000 & $\mathrm{Si}$ \\
\hline Chile & 65 & 55 & La Cuarta & Santiago & 1984 & 398.000 & SI \\
\hline Colombia & 61 & 35 & E1 Tiempo & Bogota & 1911 & 250.000 & $\mathrm{Si}$ \\
\hline Costa Rica & 56 & 11 & La Nación & San Josí & 1946 & 88.000 & $\mathrm{Si}$ \\
\hline Cuba & 18 & 25 & Granua & La Habana & 1965 & 200.000 & $\mathrm{Si}$ \\
\hline Ecuador & 47 & 36 & El Universo & Guayaquil & 1921 & 350.000 & $\mathrm{Si}$ \\
\hline Guatemala & 12 & 12 & Nuastro Diario & Guatemala & 1996 & 200.000 & Si \\
\hline Honduras & 8 & 9 & La Prensa & Sula & 1964 & 60.000 & $\mathrm{Si}$ \\
\hline Mérico & 510 & 450 & E1Metro & México DF & 1997 & 500.000 & $\mathrm{Si}$ \\
\hline Nicaragua & 4 & 4 & La Prensa & Managua & 1926 & 50.000 & $\mathrm{Si}$ \\
\hline Panama & 6 & 6 & La Prensa & Panama & 1980 & 60.000 & $\mathrm{Si}$ \\
\hline Paraguay & 5 & 5 & ABC Color & Assunción & 1967 & 40.000 & $\mathrm{Si}$ \\
\hline Peris & 101 & 68 & E1 Comercio & Lima & 1839 & 100.000 & $\mathrm{Si}$ \\
\hline Unuguay & 10 & 10 & E1 Pais & Montevidso & 1918 & 40.000 & $\mathrm{Si}$ \\
\hline $\begin{array}{c}\text { Repiblica } \\
\text { Dominicana }\end{array}$ & 9 & 10 & ListínDiario & St. Domingo & 1981 & 80.000 & $\mathrm{Si}$ \\
\hline E1 Salvador & 6 & 6 & $\begin{array}{l}\text { La Prensa } \\
\text { Gráica }\end{array}$ & San Salvador & 1915 & 40.000 & $\mathrm{Si}$ \\
\hline Venezuela & 109 & 120 & E1 Universal & Caracas & 1909 & 70.000 & $\mathrm{Si}$ \\
\hline
\end{tabular}

Fuente: WAN WORLD TRENDS, 2013. Datos de 2012 y 2011. En los casos en los que el informe mundial de WWT no aporta datos, éstos proceden de los propios medios o de fuentes nacionales de los respectivos países. La mayoría de los datos de circulación proceden de fuentes nacionales o de las propias editoras.

Cuadro 2. Estructura de la prensa iberoamericana, 2009

\begin{tabular}{|c|c|c|c|c|c|c|c|}
\hline País & $\begin{array}{l}\text { Núm diarios } \\
\text { impresos }\end{array}$ & $\begin{array}{l}\text { Núm. } \\
\text { diarios } \\
\text { digitales }\end{array}$ & $\begin{array}{l}\text { Primer diario } \\
\text { en difusion }\end{array}$ & $\begin{array}{l}\text { Lugar de } \\
\text { edición }\end{array}$ & $\begin{array}{l}\text { Año de } \\
\text { fundación }\end{array}$ & Circulación & $\begin{array}{l}\text { Multimedi } \\
\text { a }\end{array}$ \\
\hline Argentina & 182 & 134 & Clarin & Buenos Aires & 1945 & 376000 & $\mathrm{Si}$ \\
\hline Brasil & 532 & 223 & A Folha & Sao Paulo & 1921 & 311000 & $\mathrm{Si}$ \\
\hline Bolivia & 25 & 16 & E1 Deber & Santa Cruz & 1953 & 15.000 & $\mathrm{Si}$ \\
\hline Chile & 59 & 46 & E1 Mercurio & Santiago & 1827 & 175000 & SI \\
\hline Colombia & 39 & 31 & E1 Tiempo & Bogotá & 1911 & 361.000 & $\mathrm{Si}$ \\
\hline Costa Rica & 13 & 13 & La Nación & San Joge & 1946 & 94.000 & $\mathrm{Si}$ \\
\hline Cuba & 18 & 25 & Grangua & La Habana & 1965 & 400000 & No \\
\hline Ecuador & 35 & 22 & E1 Universo & Guayaquil & 1921 & 374000 & $\mathrm{Si}$ \\
\hline Guatemala & 10 & 10 & Nuestro Diario & Guateruala & 1996 & 229000 & $\mathrm{Si}$ \\
\hline Honduras & 6 & 6 & La Prenas & San P de Sula & 1964 & 50.000 & $\mathrm{Si}$ \\
\hline Mérico & 313 & 225 & La Prence & México DF & 1928 & 315000 & $\mathrm{Si}$ \\
\hline Nicaragua & 6 & 6 & La Prensa & Managua & 1926 & 42000 & $\mathrm{Si}$ \\
\hline Panamá & 7 & 10 & La Crítica & Panamá & 1958 & 55.000 & $\mathrm{Si}$ \\
\hline Paraguay & 6 & 6 & ABC Color & Asunción & 1967 & 50.000 & $\mathrm{Si}$ \\
\hline Perí & 86 & 38 & E1 Comercio & Lima & 1839 & 199000 & $\mathrm{Si}$ \\
\hline Ureguay & 28 & 15 & E1 Pais & Montevidso & 1918 & 46.000 & $\mathrm{Si}$ \\
\hline $\begin{array}{l}\text { Republica } \\
\text { Dominicana }\end{array}$ & 9 & 9 & Hoy & Santo Domingo & 1981 & 85.000 & $\mathrm{Si}$ \\
\hline E1 Salvador & 10 & 10 & Diario Hoy & Salvad $\alpha$ & 1915 & 70.000 & $\mathrm{Si}$ \\
\hline Venezuda & 92 & 66 & $\begin{array}{l}\text { Ütimas } \\
\text { Noticias }\end{array}$ & Caracas & 1941 & 300000 & $\mathrm{Si}$ \\
\hline
\end{tabular}

Fuente: Elaboración propia con información de WAN (World Association of Newspapers, World Press Trends 2009), datos 2008

Fue elaborado también un Cuaderno de análisis de seguimiento de la actualización, que no se reproduce por limitación de espacio pero que obra en el dossier completo de la investigación. Recoge la evolución comparativa de los titulares de las ediciones digitales e impresas de la muestra durante los días 14 y 15 de marzo de 2014, para ver 
en cuál de ellas entra cronológicamente primero la tematización de la actualidad informativa. Se tomó como referencia para la representación de la muestra de la noticia más destacada de cada una de las ediciones con el fin de efectuar su seguimiento.

De los 19 diarios latinoamericanos fueron analizadas 126 noticias digitales y 36 de las primeras páginas impresas. El tema principal de primera página entró en primer lugar en 6 ediciones digitales (El Clarín de Argentina, El Deber de Bolivia, El Universo de Ecuador, La Prensa de Honduras, El Comercio de Perú, y El País de Uruguay).

Como se comprobó a través de la investigación empírica y que explicamos anteriormente, en la mayor parte de las ediciones digitales de los periódicos de referencia latinoamericanos el enfoque del tema principal de la agenda entra a través de esas versiones on line. Sólo en cinco ediciones impresas ( La Nación de San José-Costa Rica, La Prensa de Managua -Nicaragua, La Prensa de Panamá, ABC Color de Asunción -Paraguay, La Prensa Gráfica de San Salvador -El Salvador) prevalece el temario de la versión escrita sobre la digital.

Cinco diarios ( de Belo Horizonte -Brasil, de Santiago -Chile, El Tiempo de Bogotá Colombia, Listín Diario de Santo Domingo -República Dominicana, El Universal de Caracas -Venezuela) sobresalen por destacar temas distintos en sus respectivas ediciones digitales e impresas. Este dato resulta interesante en un escenario de diversificación de los contenidos redaccionales y de optimización de modelos de negocio. Se podría decir, pues, que la edición digital gratuita de estos cinco diarios no compite directamente con su versión impresa de pago.

Dos diarios (Nuestro Diario de Guatemala y El Metro de México DF) no pudieron ser analizados a plenitud ya que no se puedo comprobar la multimedialidad, hipermedialidad, actualización permanente, simultaneidad, interconectividad e interactividad; en virtud de que el primero volca todo el diario impreso en un formato electrónico especial a su versión digital y el segundo no dispone de un sitio web; -los buscadores nos remiten a una cuenta de Twitter.

El análisis de contenido comparativo refleja que en el temario prevalecen las noticias de contenido social (sociedad), de política, deportes y economía. Si segmentamos un poco más esos cuatro grandes capítulos sobresale especialmente el tema social y político tanto en las agendas de las ediciones digitales como impresas.

En el total de noticias de las primeras páginas impresas y digitales sobresale la temática de Sociedad. En las ediciones digitales de los 19 diarios estudiados registramos 98 noticias de temática social y veinte en la versión impresa. En segundo lugar destaca el tema Político, sobre la que localizamos 54 notas en las ediciones digitales y diez en las versiones impresas.

La frecuencia de actualización de la mayor parte de los principales ciberdiarios latinoamericanos está directamente relacionada con la generación de información de actualidad inmediata aunque mantienen unos parámetros medios de intervalo de entre dos a cuatro horas. Otras cabeceras periodísticas condicionan su actualización a la publicación primero de sus informaciones principales en la edición impresa. 
La media de noticias (promedio superior) en las primeras páginas de las ediciones impresas es de 7 y de 45 en las versiones digitales mientras que el número de fotos es de 5 en el primer caso y de 30 en el segundo. En las ediciones digitales destaca también el número de elementos interactivos como galerías fotográficas, videos, audios, incremento en el uso de las redes sociales, Web TV, foros, encuestas, entre otros recursos.

Cuadro 3. Estructura de las web de la prensa latinoamericana (marzo 2014)

\begin{tabular}{|c|c|c|c|c|c|c|c|c|}
\hline País & Diarios & $\begin{array}{l}\text { Mapa } \\
\text { Web } \\
\text { Índice }\end{array}$ & $\begin{array}{l}\text { Entradas } \\
\text { mapa Web* }\end{array}$ & $\begin{array}{l}\text { Número } \\
\text { de blogs }\end{array}$ & $\begin{array}{l}\text { Número } \\
\text { de foros }\end{array}$ & $\begin{array}{c}\text { Videoblogs } \\
\text { o Web TV }\end{array}$ & $\begin{array}{c}\text { Normas de } \\
\text { Accesibilidad }\end{array}$ & $\begin{array}{c}\text { Rank. Alexa } \\
\text { 17-03-2014 }\end{array}$ \\
\hline Argentina & Clarín & Índice & $5+49=54$ & 94 & & $\mathrm{Si}$ & $\mathrm{Si}$ & 658 \\
\hline Brasil & $\begin{array}{l}\text { Super } \\
\text { Noticia }\end{array}$ & Índice & $15+27=42$ & - & & $\mathrm{Si}$ & $\mathrm{Si}$ & 24,063 \\
\hline Bolivia & El Deber & índice & $8+14=22$ & - & & $\mathrm{Si}$ & $\mathrm{Si}$ & 14,626 \\
\hline Chile & La Cuarta & No & $3+39=42$ & 1 & 1 & $\mathrm{Si}$ & $\mathrm{Si}$ & 11,941 \\
\hline Colombia & El Tiempo & $\mathrm{Si}$ & $5+18=23$ & 10 & 54 & $\mathrm{Si}$ & $\mathrm{Si}$ & 1,66 \\
\hline Costa Rica & La Nación & $\mathrm{Si}$ & $12+101=113$ & 38 & 10 & $\mathrm{Si}$ & $\mathrm{Si}$ & 6,337 \\
\hline Cuba & Granma & No & 7 & 16 & & $\mathrm{Si}$ & No & 224,222 \\
\hline Ecuador & El Universo & $\mathrm{Si}$ & $8+49=57$ & - & - & $\mathrm{Si}$ & $\mathrm{Si}$ & 7,030 \\
\hline Guatemala & - & - & - & - & - & - & - & - \\
\hline Honduras & La Prensa & Índice & $13+10=23$ & 16 & 1 & $\mathrm{Si}$ & $\mathrm{Si}$ & \\
\hline México & El Metro & - & - & - & - & - & - & - \\
\hline Nicaragua & La Prensa & $\mathrm{Si}$ & $14+5=19$ & 3 & & $\mathrm{Si}$ & $\mathrm{Si}$ & 8,622 \\
\hline Panamá & La Prensa & $\mathrm{Si}$ & $5+51=56$ & 6 & 1 & $\mathrm{Si}$ & $\mathrm{Si}$ & 15,613 \\
\hline Paraguay & ABC Color & $\mathrm{Si}$ & $6+64=70$ & 28 & 2 & $\mathrm{Si}$ & $\mathrm{Si}$ & 7,436 \\
\hline Perú & $\begin{array}{l}\text { El } \\
\text { Comercio }\end{array}$ & No & 13 & - & - & $\mathrm{Si}$ & $\mathrm{Si}$ & 1,330 \\
\hline Uruguay & El País & No & $11+42=53$ & - & - & $\mathrm{Si}$ & No & 6,888 \\
\hline $\begin{array}{l}\text { República } \\
\text { Dominicana }\end{array}$ & $\begin{array}{l}\text { Listín } \\
\text { Diario }\end{array}$ & $\mathrm{Si}$ & 31 & 16 & 1 & $\mathrm{Si}$ & No & 5,365 \\
\hline El Salvador & $\begin{array}{l}\text { La Prensa } \\
\text { Gráfica }\end{array}$ & $\mathrm{Si}$ & $12+27=39$ & 26 & 1 & $\mathrm{Si}$ & $\mathrm{Si}$ & 16,408 \\
\hline Venezuela & $\begin{array}{l}\text { El } \\
\text { Universal }\end{array}$ & $\mathrm{Si}$ & $9+35=44$ & 20 & 1 & $\mathrm{Si}$ & $\mathrm{Si}$ & 1,92 \\
\hline
\end{tabular}

* Web Índice: Las primeras cifran hacen referencia a las entradas principales y las segundas a subentradas y posteriormente se presenta el total. Fuente: Elaboración propia con información de las Web de cada medio y los datos del rank. corresponden a la consulta de Alexa en marzo de 2014 www.alexa.com 
Cuadro 4a. Ciberparticipación en la prensa de Norte y Centroamárica (marzo 2014)

\begin{tabular}{|c|c|c|c|c|c|c|c|c|}
\hline Diarios & País & $\begin{array}{l}\text { Título de } \\
\text { primera } \\
\text { noticia de } \\
\text { mayor } \\
\text { participación }\end{array}$ & $\begin{array}{l}\text { Número } \\
\text { de } \\
\text { contactos } \\
\text { de } \\
\text { primera } \\
\text { noticia }\end{array}$ & $\begin{array}{l}\text { Categoría } \\
\text { a la que } \\
\text { pertenece } \\
\text { la } 1^{\mathrm{a}} \\
\text { noticia }\end{array}$ & $\begin{array}{l}\text { Segunda } \\
\text { noticia } \\
\text { más } \\
\text { participada }\end{array}$ & $\begin{array}{l}\text { Núm. } \\
\text { contactos } \\
\text { de la } 2^{\mathrm{a}} \\
\text { noticia }\end{array}$ & $\begin{array}{l}\text { Categoría } \\
\text { de } \\
\text { la } 2 \\
\text { noticia }\end{array}$ & $\begin{array}{l}\text { Núm. noticias } \\
\text { de } 1^{\mathrm{a}} \text { pág. } \\
\text { Participadas }\end{array}$ \\
\hline La Nación & Costa Rica & $\begin{array}{l}\text { Cinco } \\
\text { empresas } \\
\text { nacionales } \\
\text { proponen } \\
\text { ampliar nueva } \\
\text { ruta a Limón } \\
14 / 03 / 14 \\
19 \mathrm{~h} 46 \\
\end{array}$ & $\begin{array}{l}16 \\
\text { comentario } \\
\text { s y cada } \\
\text { uno tiene } \\
\text { respuestas } \\
\text { y "me } \\
\text { gusta". }\end{array}$ & Economía & $\begin{array}{l}\text { Precio del } \\
\text { dólar tuvo ayer } \\
\text { su mayor caída } \\
\text { diária desde } \\
2006 \\
14 / 03 / 14 \\
19 \mathrm{~h} 47\end{array}$ & $\begin{array}{l}15 \\
\text { comentario } \\
\text { s y cada } \\
\text { uno tiene } \\
\text { respuestas } \\
\text { y "me } \\
\text { gusta". }\end{array}$ & Economía & 10 \\
\hline Granma & Cuba & 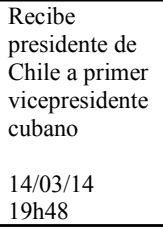 & - & Política & $\begin{array}{l}\text { Homenaje } \\
\text { martiano por } \\
\text { el Día de la } \\
\text { prensa cubana. } \\
14 / 03 / 14 \\
19 \mathrm{~h} 50\end{array}$ & - & Sociedad & 6 \\
\hline $\begin{array}{l}\text { Nuestro } \\
\text { Diario }\end{array}$ & Guatemala & - & - & - & - & - & - & - \\
\hline La Prensa & Honduras & & & & & & & \\
\hline El Metro & México & - & - & - & - & - & - & - \\
\hline La Prensa & Nicaragua & $\begin{array}{l}\text { "Recen por } \\
\text { mí", pide } \\
\text { Francisco } \\
14 / 03 / 14 \\
20 \mathrm{~h} 30\end{array}$ & 2 & Sociedad & $\begin{array}{l}\text { Nica quiere } \\
\text { ayudar a sus } \\
\text { compatriotas } \\
14 / 03 / 14 \\
20 \mathrm{~h} 35\end{array}$ & 4 & Sociedad & 10 \\
\hline La Prensa & Panamá & $\begin{array}{l}\text { Acusan a CD } \\
\text { de violar } \\
\text { derechos } \\
14 / 03 / 14 \\
20 \mathrm{~h} 38\end{array}$ & $\begin{array}{l}\text { Tweets } 32 \\
\text { y } 12 \text { "me } \\
\text { gusta". }\end{array}$ & Sociedad & $\begin{array}{l}\text { Isabel De } \\
\text { Saint Malo: } \\
\text { 'Esto solo se } \\
\text { vive en } \\
\text { dictadura' } \\
14 / 03 / 14 \\
20 \mathrm{~h} 40\end{array}$ & $\begin{array}{l}\text { Tweets } 24 \\
\text { y } 53 \text { "mes } \\
\text { gusta" }\end{array}$ & Política & 10 \\
\hline $\begin{array}{l}\text { Listín } \\
\text { Diario }\end{array}$ & $\begin{array}{l}\text { República } \\
\text { Dominican } \\
\text { a }\end{array}$ & $\begin{array}{l}\text { Condenan la } \\
\text { actitud de } \\
\text { Caricom } \\
14 / 03 / 14 \\
21: 16\end{array}$ & 28 & Política & $\begin{array}{l}\text { Migración } \\
\text { advierte que } \\
\text { RD no actuará } \\
\text { bajo } \\
\text { imposición } \\
\text { 14/03/14 } \\
21: 20 \\
\end{array}$ & 24 & Sociedad & 43 \\
\hline $\begin{array}{l}\text { La Prensa } \\
\text { Gráfica }\end{array}$ & El Salvador & $\begin{array}{l}\text { ARENA } \\
\text { incrementa } \\
\text { acciones ante } \\
\text { escrutinio } \\
\text { final } \\
\text { 14/03/14 } \\
\text { 21:08 }\end{array}$ & 1001 & Política & $\begin{array}{l}\text { Ausentismo } \\
\text { en aulas por } \\
\text { supuesto } \\
\text { toque de } \\
\text { queda en } \\
\text { Zacatecoluca } \\
\\
14 / 03 / 14 \\
21: 12\end{array}$ & 117 & Sociedad & 4 \\
\hline
\end{tabular}

Fuente: Elaboración propia a partir de las web de los diarios de mayor circulación impresa de Latinoamérica del día 14 de marzo de 2014, en la hora del país que se identifica en cada caso. La selección de la primera y segunda noticia de mayor participación se realizó tomando en cuenta los siguientes criterios: noticias más comentadas y más leídas, esto en los medios que tenía la información, en el resto se tomó en cuenta la primera y segunda noticia de la página de apertura. 


\section{Cuadro 4b. Ciberparticipación en la prensa sudamericana (marzo 2014)}

\begin{tabular}{|c|c|c|c|c|c|c|c|c|}
\hline Diarios & País & $\begin{array}{l}\text { Título de primera } \\
\text { noticia de mayor } \\
\text { participación }\end{array}$ & $\begin{array}{l}\text { Número de } \\
\text { contactos } \\
\text { de primera } \\
\text { noticia }\end{array}$ & $\begin{array}{l}\text { Categoría } \\
\text { a la que } \\
\text { pertenece } \\
\text { la } 1^{\mathrm{a}} \\
\text { noticia }\end{array}$ & $\begin{array}{l}\text { Segunda noticia } \\
\text { más participada }\end{array}$ & $\begin{array}{l}\text { Núm. } \\
\text { contactos } \\
\text { de la } 2^{\mathrm{a}} \\
\text { noticia }\end{array}$ & $\begin{array}{l}\text { Categor } \\
\text { ía de } \\
\text { la } 2 \\
\text { noticia }\end{array}$ & $\begin{array}{l}\text { Núm. noticias } \\
\text { de } 1^{\mathrm{a}} \text { pág. } \\
\text { Participadas }\end{array}$ \\
\hline Clarín & Argentina & $\begin{array}{l}\begin{array}{l}\text { Encontraron } \\
\text { muerto al } \\
\text { diseñador Jorge } \\
\text { Ibañez }\end{array} \\
14 / 03 / 14 \\
18 \mathrm{~h} 25\end{array}$ & $\begin{array}{l}49 \\
\text { comentario } \\
\text { s y cada } \\
\text { comentario } \\
\text { tiene "me } \\
\text { gusta" }\end{array}$ & Sociedad & $\begin{array}{l}\text { El impactante video } \\
\text { del cielo lleno de } \\
\text { aviones. } \\
14 / 03 / 14 \\
18 \mathrm{~h} 33\end{array}$ & 17 & Sociedad & 26 \\
\hline $\begin{array}{l}\text { Super } \\
\text { Noticia }\end{array}$ & Brasil & $\begin{array}{l}\text { Verba maior para } \\
\text { meio ambiente } \\
14 / 03 / 14 \\
18 \mathrm{~h} 38\end{array}$ & - & Sociedad & $\begin{array}{l}\text { Alunos da região } \\
\text { Centro-Sul fazem } \\
\text { protesto e depredam } \\
\text { viatura da PM } \\
14 / 03 / 14 \\
18 \mathrm{~h} 40\end{array}$ & - & Sociedad & 27 \\
\hline El Deber & Bolivia & $\begin{array}{l}\text { Profesionales } \\
\text { recibirán su título } \\
\text { en provisión } \\
\text { nacional tras } \\
\text { graduarse } \\
\\
14 / 03 / 14 \\
18 \mathrm{~h} 48\end{array}$ & - & Sociedad & $\begin{array}{l}\text { Bálsamo en la } \\
\text { academia } \\
14 / 03 / 14 \\
18 \mathrm{~h} 50\end{array}$ & - & Sociedad & 10 \\
\hline La Cuarta & Chile & $\begin{array}{l}\text { Colombiana Leidy } \\
\text { Viveros sabe que } \\
\text { nos tiene loquitos. } \\
14 / 03 / 14 \\
19 \mathrm{~h} 03\end{array}$ & - & Sociedad & $\begin{array}{l}\text { El radical cambio } \\
\text { de look de Faloon } \\
\text { Larraguibel } \\
14 / 03 / 14 \\
19 \mathrm{~h} 04\end{array}$ & - & Sociedad & 10 \\
\hline $\begin{array}{l}\text { El } \\
\text { Tiempo }\end{array}$ & Colombia & $\begin{array}{l}\text { Fernando Gaitán } \\
\text { despide al 'ángel' } \\
\text { que transformó a } \\
\text { su 'Betty, la fea' } \\
\text { 14/03/14 } \\
\text { 19h44 }\end{array}$ & 105 & Sociedad & $\begin{array}{l}\text { Teorías } \\
\text { conspirativas por } \\
\text { avión perdido } \\
\text { incluyen hasta } \\
\text { extraterrestres } \\
\text { 14/03/14 } \\
9 \mathrm{~h} 46\end{array}$ & 53 & Sociedad & 20 \\
\hline $\begin{array}{l}\text { El } \\
\text { Universo }\end{array}$ & Ecuador & $\begin{array}{l}\text { Kate Winslet } \\
\text { tendrá su estrella } \\
\text { en Hollywood } \\
14 / 03 / 14 \\
19 \text { h55 }\end{array}$ & - & Sociedad & $\begin{array}{l}\text { Exgerrillero } \\
\text { ganador de segunda } \\
\text { vuelta en El } \\
\text { Salvador } 14 / 03 / 14 \\
19 \text { h56 }\end{array}$ & - & Sociedad & 5 \\
\hline $\begin{array}{l}\mathrm{ABC} \\
\text { Color }\end{array}$ & Paraguay & $\begin{array}{l}\text { Choque: mujer } \\
\text { murió al ver } \\
\text { cuerpo de su } \\
\text { esposo. } \\
\\
14 / 03 / 14 \\
20 \mathrm{~h} 45\end{array}$ & 263 & Sociedad & $\begin{array}{l}\text { Viajaban a "mil por } \\
\text { hora". } \\
\text { 14/03/14 } \\
20 \mathrm{~h} 47\end{array}$ & 228 & Sociedad & 10 \\
\hline $\begin{array}{l}\text { El } \\
\text { Comercio }\end{array}$ & Perú & $\begin{array}{l}\text { Aguántate, } \\
\text { por Patricia } \\
\text { del Río. } \\
14 / 03 / 14 \\
20 \mathrm{~h} 49\end{array}$ & $\begin{array}{l}2616 \text { "me } \\
\text { gusta" y } \\
104 \text { tweets. }\end{array}$ & Sociedad & $\begin{array}{l}\text { Un muerto y } \\
\text { un herido tras } \\
\text { incidente en } \\
\text { aeropuerto } \\
\text { Jorge Chávez. } \\
14 / 03 / 14 \\
20 \mathrm{~h} 52\end{array}$ & $\begin{array}{l}71 \text { "me } \\
\text { gusta" y } \\
46 \text { tweets. }\end{array}$ & Sociedad & 8 \\
\hline El País & Uruguay & $\begin{array}{l}\text { Acuerdan } \\
\text { congelar } \\
\text { durante } 60 \\
\text { días precios } \\
\text { de canasta } \\
\text { básico } \\
14 / 03 / 14 \\
21: 24\end{array}$ & 66 & Economía & $\begin{array}{l}\text { Policía hirió a dos } \\
\text { ladrones y evitó el } \\
\text { robo de una } \\
\text { estación de servicio } \\
\text { 14/03/14 } \\
21: 28\end{array}$ & 65 & Política & 18 \\
\hline $\begin{array}{l}\text { El } \\
\text { Universal }\end{array}$ & Venezuela & $\begin{array}{l}\text { Colectaron restos } \\
\text { de } 840 \text { bombas } \\
\text { lacrimógenas en } \\
\text { UCV } \\
14 / 03 / 14 \\
20: 54\end{array}$ & 32 & Sociedad & $\begin{array}{l}\text { Comando Sur } \\
\text { observa que la } \\
\text { situación "se cae en } \\
\text { pedazos" } \\
11 / 03 / 14 \\
20: 56\end{array}$ & 19 & Sociedad & 6 \\
\hline
\end{tabular}

Fuente: Elaboración propia a partir de las web de los diarios de mayor circulación impresa de Latinoamérica del día 14 de marzo de 2014, en la hora del país que se identifica en cada caso. La selección de la primera y segunda noticia de mayor participación se realizó tomando en cuenta los siguientes criterios: noticias más comentadas y más leídas, esto en los medios que tenía la información, en el resto se tomó en cuenta la primera y segunda noticia de la página de apertura. 
Cuadro 5. Promedio de noticias primeras páginas impresa y digital

\begin{tabular}{|c|c|c|c|c|c|c|c|}
\hline \multirow[b]{2}{*}{ País } & \multirow[b]{2}{*}{ Periódicos } & \multicolumn{3}{|c|}{ EDICIÓN IMPRESA } & \multicolumn{3}{|c|}{ EDICIÓN DIGITAL } \\
\hline & & No. de noticias & $\begin{array}{l}\text { No. de } \\
\text { fotos }\end{array}$ & $\begin{array}{l}\text { No. de } \\
\text { elementos de } \\
\text { publicidad } \\
\end{array}$ & No. de noticias & $\begin{array}{l}\text { No. de } \\
\text { fotos }\end{array}$ & $\begin{array}{l}\text { No. de } \\
\text { elementos de } \\
\text { publicidad }\end{array}$ \\
\hline Argentina & Clarín & 10 & 3 & 1 & 61 & 50 & 8 \\
\hline Brasil & Super Noticia & 8 & 3 & 5 & 16 & 13 & 3 \\
\hline Bolivia & El Deber & 8 & 5 & 1 & 53 & 33 & 12 \\
\hline Chile & La Cuarta & 4 & 3 & 2 & 36 & 20 & 7 \\
\hline Colombia & El Tiempo & 6 & 2 & 9 & 28 & 30 & 19 \\
\hline Costa Rica & La Nación & 4 & 3 & 1 & 56 & 22 & 6 \\
\hline Cuba & Granma & 2 & 4 & 0 & 29 & 8 & 5 \\
\hline Ecuador & El Universo & 8 & 7 & 1 & 24 & 16 & 7 \\
\hline Guatemala & $\begin{array}{l}\text { Nuestro } \\
\text { Diario* }\end{array}$ & 3 & 3 & 1 & 3 & 3 & 1 \\
\hline Honduras & La Prensa & 5 & 5 & 1 & 57 & 41 & 20 \\
\hline México & El Metro** & - & - & - & - & - & - \\
\hline Nicaragua & La Prensa & 6 & 3 & 4 & 43 & 24 & 15 \\
\hline Panamá & La Prensa & 9 & 2 & 4 & 36 & 7 & 8 \\
\hline Paraguay & ABC Color & 6 & 1 & 2 & 32 & 24 & 8 \\
\hline Perú & El Comercio & 11 & 7 & 1 & 50 & 49 & 4 \\
\hline Uruguay & El País & 9 & 2 & 3 & 50 & 46 & 4 \\
\hline $\begin{array}{l}\text { República } \\
\text { Dominicana }\end{array}$ & Listín Diario & 9 & 4 & 1 & 47 & 17 & 11 \\
\hline El Salvador & $\begin{array}{l}\text { La Prensa } \\
\text { Gráfica } \\
\end{array}$ & 6 & 1 & 1 & 16 & 10 & 4 \\
\hline Venezuela & El Universal & 14 & 8 & 2 & 42 & 10 & 10 \\
\hline
\end{tabular}

Fuente: Elaboración propia con información de las Web de cada medio. Información recolectada el 14 y 15 de marzo 2014.

* La versión impresa y digital del periódico Nuestro Diario es la misma. ** Diario El Metro no cuenta con página Web.

\subsection{Conclusiones}

La prensa latinoamericana de referencia marca ya su tematización principal a través de sus ediciones digitales según destacan los resultados del análisis efectuado sobre las primeras páginas electrónicas e impresas de 19 diarios. Cinco de ellos mantienen agendas temáticas separadas entre las ediciones digital e impresa, lo que evidencia que las empresas periodísticas apuestan mayoritariamente por una oferta informativa global, aún a costa de que sus propias producciones electrónicas y en papel compitan entre sí por la retención de los lectores. El estancamiento de la circulación de las ediciones impresas, como reflejan las cifras comparativas entre 2008 y 2013, marcan una tendencia de obligatoria reflexión estratégica para las empresas editoras en ese aspecto. 
La evolución de la estructura de las ediciones digitales en 2009, con una perspectiva de diez meses, entre enero y finales de octubre, apuntan también a la simplificación de la arquitectura de los ciberdiarios con más elementos y mejor precisión en sus respectivos mapas web y aumento de blogs. Sin embargo varios de ellos han suprimido sus foros y no han mejorado de forma sustancial los elementos multimedia (videoblogs o web TV). Las políticas de accesibilidad se mantienen prácticamente inalterables en los diarios en el transcurso de esos diez meses. Para el 2014 se registran cambios significados, especialmente, en el uso de las redes sociales, las audiencias cada vez son más interactivas y prefieren informarse a través de ellas antes de que por los propios diarios. Todos los diarios (excepto dos que no registran página web) tienen videoblogs o web tv, además se ha incrementado el número de participaciones e interacciones de los usuarios a través de las redes sociales y de los comentarios en cada noticia.

Es especialmente relevante la lectura que se puede sacar del balance de las temáticas de las primeras páginas de las ediciones impresas y digitales elaboradas por los periodistas con los criterios de popularidad en la ciberparticipación. La mayoría de las noticias seleccionadas en las primeras páginas impresas y digitales son de sociedad, seguidas de política, deportes y economía. Sin embargo, las noticias más populares, preferentemente elegidas y con mayor número de ciberpartición son las de sociedad, seguidas por las de política y economía. Para obtener este llamativo dato se contabilizaron la primera y segunda noticias con mayor ciberparticipación de las primeras páginas de las ediciones digitales. Con este dato a la vista, se podría decir que los ciberlectores reaccionan e interactúan mucho más con los temas frívolos que los serios y politizados.

De acuerdo con los datos de la WAN 2008 los diarios que lideraban la circulación en Brasil, Chile, México, Panamá, República Dominicana y Venezuela eran diarios de élite, más serios en contenidos, mientras que en la muestra de 2012 se ven desplazados por cabeceras de corte popular; es el caso de $A$ Folha que hace cuatro años era el diario con mayor circulación en Brasil y que hoy es reemplazo por Super Noticias; El Mercurio de Chile por diario La Cuarta; La Prensa de México por diario El Metro; y La Crítica de Panamá por diario La Prensa; Hoy de República Dominicana por Listín Diario; y en Venezuela Ultimas Noticias por El Universal.

La lectura crítica de ese contraste tiene que ser aún moderada porque, en una situación de multiplicidad de fuentes -incluso más populares y espectaculares que la prensa; por ejemplo, la televisión- la dieta mediática puede ya estar mediatizada y potenciada cuando llega a la prensa. Para contrastar ese resultado sería preciso efectuar un análisis simultáneo y comparativo de los principales medios que actualmente nutren la dieta informativa de los ciudadanos. Y ese análisis es para otra investigación. 


\subsection{Referencias bibliográficas}

Campos Freire, F. (2008): Gestión de nuevas empresas periodísticas, Universidad Técnica Particular de Loja. Ecuador: Editorial Universitaria.

Campos Freire, F. (2008): "Las redes sociales trastocan los modelos de los medios de comunicación tradicionales", en Revista Latina de Comunicación Social, 63, páginas 287 a 293. La Laguna (Tenerife): Universidad de La Laguna, recuperado el 20 de octubre de 2009 de

http://www.ull.es/publicaciones/latina/_2008/23_34_Santiago/Francisco_Campos.htm 1

Colón Zayas, E.R. (2009): "Del framing a las políticas de identidad: pensar la investigación en comunicación en tiempos de transición económica. El caso de lo latino y la sociedad del conocimiento", en Campos Freire, F. (2009), ed.: La gestión del cambio mediático. Sevilla: Comunicación Social

Funkhouser, G. R. (1973): "The issues of the sixties: An exploratory study in the dynamics of public opinion”. Public Opinion Quarterly, 37 (1), p. 62-75.

Giménez, P. (2006): Una nueva visión del proceso comunicativo: La teoría del Enfoque (Framing). Universidad Francisco de Vitoria.

Krippendorff, K. (1997). Metodología de análisis de contenido. Teoría y práctica. Buenos Aires: Editorial Paidós, SAICF.

McCombs, M. (2006): Estableciendo la agenda. El impacto de los medios en la opinión pública y en el conocimiento. Barcelona: Paidós Comunicación.

Noëlle-Neumann (1995): La espiral del silencio. Opinión pública: nuestra piel social. Barcelona: Paidós.

Rodríguez, R. (2004). Teoría de la Agenda-Setting aplicación a la enseñanza universitaria. España: CEE Limencop, S.L.

Varela, J. (2008): “Blogs vs. MSM. Periodismo 3.0, la socialización de la información”. Madrid: Revista Telos. 


\title{
B
}

\section{Estudio de caso de prensa digital internacional: hipertextualidad, multimedia e interactividad en USA Today, Le Monde, The Telegraph y Clarín}

\author{
Dr. Joan Francesc Fondevila Gascón \\ jfondevilag@uao.es \\ Dra. Ana Beriain Bañares \\ Marc Perelló Sobrepere \\ Victoria Barbero González \\ Universitat Abat Oliba CEU (UAO CEU)
}

\subsection{Introducción}

Cada vez es más frecuente asistir al cierre de cabeceras históricas que solían imprimir en papel, pero también asistimos al cierre de cabeceras originadas directamente en internet. Muchos usuarios se quejan de que la experiencia en línea no es la que cabría esperar del siglo en el que vivimos. Una queja también recogida por muchos académicos. ¿Utilizan mal los medios de comunicación las herramientas digitales? En esta investigación nos adentramos, mediante un estudio empírico, en el uso que hacen de la hipertextualidad, el multimedia y la interactividad reconocidas cabeceras con prestigio y presencia internacional: Le Monde (Francia), The Telegraph (Reino Unido), USA Today (Estados Unidos) y Clarín (Argentina). Tomamos un período de 51 días consecutivos en el primer cuatrimestre del año 2013, y analizamos el número total de noticias en la homepage, el uso del hipertexto (cantidad de enlaces incluidos; enlaces internos o externos; enlaces contextuales, relacionales, recomendados o científicos); del multimedia (inclusión de texto, vídeo, fotografía, audio o infografía); y de la interactividad (cantidad de comentarios y entrevistas online). Ello alumbra las futuras estrategias de educación sobre comunicación digital. 


\subsection{Sociedad de la Banda Ancha y Prensa Digital}

Las nuevas tecnologías de la información y la comunicación se vieron catalizadas a finales del siglo XX y principios del XXI gracias a la implementación progresiva de la banda ancha, en sí misma una de las mayores tecnologías de la comunicación (Bangemann, Delors, 1993). El desarrollo del cable no sólo trajo consigo una mayor velocidad para los proveedores y los usuarios de información, sino también una cambio de paradigma en cómo se estructura el trabajo en una redacción periodística (Fondevila, 2010a). Así, nos encontramos con periodistas multitasking que rara vez pisan la redacción, y que sin embargo producen más y mejores contenidos que nunca. Estos contenidos tienen en su haber un sinfín de formatos visuales englobados dentro de las tecnologías multimedia y en lo que se ha llamado era digital (Merrit y McCombs, 2004). Todas estas novedades sacudieron a una sociedad a menudo tildada de dormida, y se generó una importante revolución mediática (Levinson, 2007).

El 17 de julio de 1995, The Washington Post se convertía en uno de los periódicos pioneros en salir a la venta en versión digital. Desde entonces, la digitalización de las principales cabeceras tradicionales, así como el nacimiento de periódicos dentro de la red (pure players), forjaron un drástico cambio en el modo de consumir información (Fondevila, Sierra y Del Olmo, 2011). En la actualidad, un 22\% de medios de comunicación trabajan exclusivamente en un entorno digital. Las nuevas tecnologías han auspiciado paralelamente el nacimiento del cloud journalism, elemento a su vez englobado en el cloud computing. La filosofía cloud permite a particulares y empresas periodísticas guardar sus archivos y procesos electrónicos "en la nube", un servidor virtual accesible desde cualquier parte. Asimismo, el cloud computing permite que los usuarios puedan acceder a multitud de servicios técnicos sin necesidad de que ellos mismos sean expertos en esos servicios. Trasladado al periodismo, esto significa que existe una necesidad constante de alimentar los contenidos en red, tanto a los diarios como a otras empresas de comunicación. Este nuevo escenario está generando un conocimiento especializado y a su vez un periodismo también muy especializado. Estudiar la relación entre esos vectores del periodismo digital permite guiar estrategias de educación sobre comunicación digital.

\subsubsection{La hipertextualidad}

La hipertextualidad es el primer factor que revoluciona la prensa digital. Con la llegada de la hipertextualidad se rompen la unidireccionalidad y unilinealidad que caracterizaban los medios informativos tradicionales. Asimismo, la hipertextualidad ha favorecido la creación de una semántica casi infinita de enlaces y combinaciones de todo tipo. La hipertextualidad permite también un desarrollo paralelo de contenidos que los medios tradicionales no pueden alcanzar en absoluto. Otro de los factores que ha traído la hipertextualidad es el avance del cloud journalism, así como un análisis temático de la semántica de los enlaces y los contenidos de los medios digitales 
(Fondevila, 2010a).

El estudio de la hipertextualidad se convive como algo intrínsecamente unido a la prensa digital y fundamental tanto para la mejora de la calidad de los contenidos que se ofrecen en los medios digitales como para el estímulo de fórmulas que potencien los modelos de negocio online, como las mismas empresas periodísticas. Prueba de ello es que el impacto del hipertexto en los géneros periodísticos se refleja en blogs y listas de correo (Fondevila, 2009a) y en el reportaje hipertextual (Larrondo, 2009). De igual modo sucede con la importancia de la hipertextualidad y la interactividad en redes sociales (Ivars, 2012; Beriain, Fondevila y García, 2012).

Algunos medios digitales realizan con frecuencia un uso de la hipertextualidad exógena, que es aquella que conduce a páginas webs externas que de un modo u otro pueden ser competencia del propio medio digital desde el que se origina el enlace. Por el contrario, también se produce un gran uso de la hipertextualidad endogámica, que es aquella en la que los enlaces apuntan a páginas o secciones internas del mismo medio digital. El mal uso de la hipertextualidad puede degenerar en un modelo de negocio poco sostenible, en la pérdida de audiencia, y en una superficialidad semántica (Fondevila, 2010b, 2011; Fondevila y Segura, 2012).

Anteriormente ya se han realizado estudios acerca de los enlaces de las noticias en los medios digitales, como los de Deuze (2003), Oblak (2005), Engebretsen (2006), Quandt (2008) y Castellanos (2011), pero estos no contemplaban la semántica de la hipertextualidad. Esta semántica, que sí se investiga en nuestro estudio, hace referencia a los tres tipos tradicionales de enlaces, los contextuales -directamente relacionados con la noticia-, los relacionales -indirectamente relacionados con la noticia: precedentes y casos similares- y los recomendados -documentación sobre la noticia, denotan profundidad semántica: estadísticas, tablas de datos, blogs- (Fondevila, 2011). También añadimos, como en pasadas investigaciones (Fondevila, Beriain, Del Olmo, 2013), los enlaces científicos (documentación científica sobre el hecho de la noticia, la más profunda semánticamente: artículos científicos y blogs científicos).

\subsubsection{Elementos multimedia}

Las nuevas tecnologías han propiciado el uso de los recursos multimedia en la prensa digital. Sin embargo, el uso que se hace hoy día de los elementos multimedia sigue siendo muy reducido, tal y como se desprende de investigaciones anteriores (Fondevila, 2009a). Entre los soportes más utilizados están el texto y la fotografía, y en menor medida el vídeo, el audio, y la infografía. Los datos que reflejamos en esta investigación tienen su parte irónica, pues cabría pensar que en pleno siglo XXI el vídeo, el audio y la infografía estarían a pleno uso, y sin embargo los resultados obtenidos señalan todo lo contrario, tal y como ya sucediera en investigaciones anteriores (Fondevila, Beriain, Del Olmo, 2013). Y es que a pesar de la enorme influencia que internet ha tenido para los medios de comunicación (Salaverría, 2005), son muchos los que todavía se resisten a aplicar la innovación digital que brindan los elementos multimedia. 
Algunos investigadores han apuntado ya como la prensa digital hereda, a priori, el mayor uso de texto y foto de la prensa tradicional, así como el hecho de que muchas cabeceras digitales sean meramente una reproducción de las cabeceras tradicionales en papel (Castellanos, 2011; Bachmann y Harlow 2012). Y si bien es cierto que la mayoría de medios tienen presencia en las redes sociales y que han logrado una amplia interacción con la sociedad (Perelló, 2012), también lo es que muchos medios no van más allá de tener sus cuentas semi-activas en las redes sociales, perdiendo así una gran oportunidad de establecer un mayor contacto y dinamismo con su audiencia.

\subsubsection{La interactividad}

La interactividad es una temática que suscita el interés de profesionales y académicos desde que se vislumbró como una posibilidad real para el usuario. Hace unos pocos años, a pesar de que la mayoría de medios se movían por internet, la interactividad estaba considerada como una asignatura pendiente (Goldenberg, 2005). La interactividad nos propone múltiples posibilidades dentro de lo que se ha denominado como social engagement. Con esta relación más directa entre medios y sociedad se eliminan las barreras de periodismo tradicional (McNair, 1998) y se apuesta por un nuevo modelo de periodismo (Fondevila y Beriain, 2012). Recientemente, Díaz Noci (2004) ayudó a crear un marco teórico acerca de la interactividad que la clasifica según el tipo (inclusiva o autorial), la estructura (aleatoria, fija, relacional, contributiva), el grado de dialogismo (simétrico o asimétrico), la temporalidad (sincrónica o asincrónica), la técnica (dialógica o personalizada) y la intervención del medio (con moderación o sin moderación). Estas características propias de la interactividad ayudan al lector a sentirse más cercano a la información, al medio, e incluso a otros lectores, propiciando así una mejor experiencia.

En esta investigación veremos cómo, a fecha de 2013, la interactividad se mantiene como uno de los pilares a mejorar en la prensa digital. Así, al comparar los contenidos de periódicos digitales y periódicos impresos, apreciamos vacíos en el uso de la interactividad (Oblak, 2005), fortaleciendo así la idea de que estamos ante un campo que aún tiene mucho recorrido y mucho por mejorar. Además, esta necesidad aumenta si tenemos en cuenta la velocidad expansiva de las redes sociales y el tipo de comunicación que éstas favorecen: comunicación instantánea (Castellanos, 2011). El mero hecho de abrir una columna de comentarios en las noticias se ha demostrado como una garantía de participación entre los usuarios (Fondevila, 2009a). La satisfacción es mayor si hablamos de periódicos pure players (Fondevila, 2009b). Pero aún hay mucho para mejorar. Bachmann y Harlow (2012) defienden la incorporación progresiva de mayores hábitos interactivos. En este sentido, los autores encuentran carencias en la posibilidad de contactar con los redactores de una noticia, avisar de errores, o crear su propio contenido. En esta investigación observaremos, por ejemplo, como efectivamente sigue habiendo carencias de tipo interactivo en los medios analizados. 


\subsection{Metodología}

Esta estudio se ha realizado siguiendo una metodología cuantitativa de carácter comparativo en base a las ediciones digitales de los periódicos Le Monde (http://www.lemonde.fr/), USA Today (http://www.usatoday.com), Clarín (http://www.clarin.com) y The Telegraph (http://www.telegraph.co.uk). Estos cuatro diarios ocupan las posiciones más altas de ventas en sus respectivos países (Francia, Estados Unidos, Argentina y Reino Unido). Además, no son pure players, sino que constituyen empresas informativas de gran envergadura, lo que les convierte en candidatos ideales para este estudio.

Se han estudiado distintos parámetros y se ha aplicado estadística descriptiva y relacional contabilizando días consecutivos ( $\mathrm{n}=51$ por cada medio). Para la obtención de los resultados se ha aplicado el Análisis de Varianza (ANOVA) a los resultados adquiridos en la investigación.

Para contabilizar los resultados, se han tenido en cuenta las noticias ubicadas en la homepage de cada periódico y siempre en la misma franja horaria. Se consideraron como noticia todos aquellos titulares o breves que enlazaran a una noticia completa. Dentro de dichas noticias, contabilizamos todos los enlaces comprendidos en el cuerpo del texto y los clasificamos según su destino (interno, externo) y según su profundidad semántica (contextual, relacional, recomendado, científico). Asimismo, se registraron también las inserciones multimedia como imágenes, vídeos, audios e infografías, y se hizo lo propio con aquellos elementos interactivos como los comentarios y las entrevistas.

Las hipótesis de la investigación son las siguientes:

H1. El número de noticias no es correlativo al número de enlaces.

H2. Escasean los enlaces de tipo recomendado y científico.

H3. El texto y la fotografía siguen predominando ante el vídeo, el audio y la infografía.

H4. El número de noticias no es correlativo al número de comentarios.

\subsection{Resultados}

En la Tabla 1 se observa como la media de noticias en la página principal de Clarín, con un total de 26,67, dobla a la de los otros periódicos analizados. Así, USA Today y The Telegraph comparten medias muy similares, de 10,33 y 10,92 respectivamente, mientras que Le Monde tiene una media casi dos puntos superior, de 12,06.

Sin embargo, cuando entramos a medir los enlaces de cada noticia, observamos datos muy dispares entre los distintos periódicos. A este respecto, USA Today es el periódico con un menor promedio de enlaces en sus noticias: tan solo 14,29 de media. Con más 
del doble se sitúa Clarín: 35,18. Después, The Telegraph, con 44,69. Y casi doblando al periódico inglés se encuentra Le Monde, con una media de 82,51 enlaces por página.

Con este primer análisis, podemos constatar probada la hipótesis H1, que asegura que el número de noticias no es correlativo al de enlaces. Los ratios hacen más visible esta premisa. Así, el periódico Clarín, a pesar de doblar en noticias a sus competidores, tiene el ratio de enlaces por noticia más bajo: apenas un 1,32. En cambio, sus competidores, con la mitad de noticias que el digital argentino, tienen un mayor ratio: 1,38 para USA Today; 4,09 para The Telegraph; y un espectacular 6,84 para Le Monde.

La misma tabla nos da otros ejemplos de cómo el número total o medio de enlaces no guardan relación con su destino (interno o externo). Por ejemplo, se observa que The Telegraph tiene un menor número de enlaces externos $(1,92)$, pero su ratio $(0,18)$ es mayor que la de Clarín $(0,16)$, a pesar de tener el argentino más enlaces externos $(4,39)$. Cabe destacar las medias y ratios de Le Monde, que se disparan muy por encima de las de sus compañeros. El periódico galo tiene una media de 72,12 enlaces internos y 10,39 externos.

Tabla 1: Número de enlaces

\begin{tabular}{|c|c|c|c|c|}
\hline & Le Monde & USA Today & Clarín & $\begin{array}{c}\text { The } \\
\text { Telegraph }\end{array}$ \\
\hline Total & $\begin{array}{c}51 \\
\text { a }\end{array}$ & $\begin{array}{c}51 \\
b\end{array}$ & $\begin{array}{c}51 \\
\text { c }\end{array}$ & $\begin{array}{c}51 \\
\text { d }\end{array}$ \\
\hline \multicolumn{5}{|c|}{ Noticias de la página principal } \\
\hline Media & $12,06 \mathrm{bd}$ & 10,33 & 26,67 abd & $10,92 \mathrm{~b}$ \\
\hline \multicolumn{5}{|c|}{ Links de todas las noticias } \\
\hline Media & 82,51 bcd & 14,29 & $35,18 \mathrm{~b}$ & 44,69 bc \\
\hline Ratio & 6,84 & 1,38 & 1,32 & 4,09 \\
\hline \multicolumn{5}{|c|}{ Links internos } \\
\hline Media & 72,12 bcd & 8,92 & $30,78 \mathrm{~b}$ & $42,76 \mathrm{bc}$ \\
\hline Ratio & 5,98 & 0,86 & 1,15 & 3,92 \\
\hline \multicolumn{5}{|c|}{ Links externos } \\
\hline Media & 10,39 bcd & $5,37 \mathrm{~d}$ & $4,39 \mathrm{~d}$ & 1,92 \\
\hline Ratio & 0,86 & 0,52 & 0,16 & 0,18 \\
\hline
\end{tabular}

Las letras indican diferencias estadísticamente significativas al 95\% de confianza Fuente: elaboración propia

En la Tabla 2 hemos explorado la profundidad semántica de los enlaces. Es decir, si éstos son contextuales, relacionales, recomendados o científicos. Para esta tabla, se parte de la hipótesis $\mathrm{H} 2$ : los enlaces de tipo relacional y científico son escasos. Y, efectivamente, la hipótesis queda demostrada.

Como en la anterior categoría, Le Monde destaca por encima de los otros periódicos analizados. El digital francés promedia 40,49 enlaces contextuales y 39,27 enlaces relacionales. Le siguen, lejos, Clarín, con 23,57 contextuales y 11,08 relacionales; The 
Telegraph, con 23,20 enlaces contextuales y 20,6 relacionales; y USA Today, con 9,82 contextuales y 3,43 relacionales.

En la misma tabla podemos observar que la cantidad de enlaces recomendados y científicos es casi residual en todos los periódicos analizados. Más ínfima aún es la cifra reflejada por los ratios. Los números se mueven entre el 0,01 y el 0,20 para los enlaces recomendados, y entre el 0,00 y el 0,02 para los científicos. Se prueba así, como ya avanzábamos, la hipótesis $\mathrm{H} 2$.

Tabla 2: Número de enlaces según profundidad semántica

\begin{tabular}{|c|c|c|c|c|}
\hline & Le Monde & USA Today & Clarín & $\begin{array}{c}\text { The } \\
\text { Telegraph }\end{array}$ \\
\hline Total & $\begin{array}{c}51 \\
a\end{array}$ & $\begin{array}{l}51 \\
b\end{array}$ & $\begin{array}{c}51 \\
c\end{array}$ & $\begin{array}{l}51 \\
\mathrm{~d}\end{array}$ \\
\hline \multicolumn{5}{|c|}{ Noticias de la página principal } \\
\hline Media & $12,06 \mathrm{bd}$ & 10,33 & 26,67 abd & $10,92 \mathrm{~b}$ \\
\hline \multicolumn{5}{|c|}{ Links de todas las noticias } \\
\hline Media & 82,51 bcd & 14,29 & $35,18 \mathrm{~b}$ & $44,69 \mathrm{bc}$ \\
\hline Ratio & 6,84 & 1,38 & 1,32 & 4,09 \\
\hline \multicolumn{5}{|c|}{ Links contextuales } \\
\hline Media & 40,49 bcd & 9,82 & $23,57 \mathrm{~b}$ & $23,20 \mathrm{~b}$ \\
\hline Ratio & 3,36 & 0,95 & 0,88 & 2,12 \\
\hline \multicolumn{5}{|c|}{ Link relacionales } \\
\hline Media & 39,27 bed & 3,43 & $11,08 \mathrm{~b}$ & 20,63 be \\
\hline Ratio & 3,26 & 0,33 & 0,42 & 1,89 \\
\hline \multicolumn{5}{|c|}{ Links recomendados } \\
\hline Media & 2,37 bcd & $1,02 \mathrm{c}$ & 0,39 & $0,78 \mathrm{c}$ \\
\hline Ratio & 0,20 & 0,10 & 0,01 & 0,07 \\
\hline \multicolumn{5}{|c|}{ Links cientificos } \\
\hline Media & $0,20 \mathrm{bcd}$ & 0,02 & 0,02 & 0,00 \\
\hline Ratio & 0,02 & 0,00 & 0,00 & 0,00 \\
\hline
\end{tabular}

Las letras indican diferencias estadísticamente significativas al 95\% de confianza Fuente: elaboración propia

En la Tabla 3 podemos observar si la prensa digital imita el uso multimedia de la prensa en papel, lo cual describimos en la hipótesis $\mathrm{H} 3$ como un mayor uso de los recursos tradicionales (texto y fotografía) por delante de recursos intrínsecamente multimedia como los vídeos, los audios o las infografías. 
Tabla 3: Cantidad de elementos multimedia

\begin{tabular}{|c|c|c|c|c|}
\hline & Le Monde & USA Today & Clarín & The Telegraph \\
\hline \multirow{2}{*}{ Total } & 51 & 51 & 51 & 51 \\
\hline & $\mathbf{a}$ & b & c & d \\
\hline \multicolumn{5}{|c|}{ Noticias de la página principal } \\
\hline Media & 12,06 bd & 10,33 & 26,67 abd & $10,92 \mathrm{~b}$ \\
\hline \multicolumn{5}{|c|}{ Multimedia texto } \\
\hline Media & $12,61 \mathrm{bd}$ & 10,49 & 26,71 abd & $11,06 \mathrm{~b}$ \\
\hline Ratio & 0,19 & 1,02 & 1,00 & 1,01 \\
\hline \multicolumn{5}{|c|}{ Multimedia fotos } \\
\hline Media & $29,06 \mathrm{~d}$ & 57,90 acd & 34,35 ad & 20,78 \\
\hline Ratio & 2,41 & 5,60 & 1,29 & 1,90 \\
\hline \multicolumn{5}{|c|}{ Multimedia vídeo } \\
\hline Media & 2,22 & 15,69 acd & $4,25 \mathrm{a}$ & 5,55 ac \\
\hline Ratio & 0,18 & 1,52 & 0,16 & 0,51 \\
\hline \multicolumn{5}{|c|}{ Multimedia audio } \\
\hline Media & 0,00 & 0,06 ad & 0,41 abd & 0,00 \\
\hline Ratio & - & 0,01 & 0,02 & - \\
\hline \multicolumn{5}{|c|}{ Multimedia infografia } \\
\hline Media & $1,41 \mathrm{bcd}$ & $0,49 \mathrm{~cd}$ & 0,08 & $0,24 \mathrm{c}$ \\
\hline Ratio & 1,54 & 0,86 & 0,27 & 0,02 \\
\hline
\end{tabular}

Las letras indican diferencias estadísticamente significativas al 95\% de confianza Fuente: elaboración propia

El primer dato observable son las medias referentes al texto. Dado que casi todas las noticias se componen por texto, las medias son muy similares a la media de noticias en la misma página principal. Asimismo, la media de imágenes utilizadas en las noticias se dispara ampliamente con respecto al texto, siendo USA Today el digital con un mayor uso de imágenes, tanto en media $(57,90)$ como en ratio $(5,60)$. Muy por debajo se sitúan el resto de periódicos analizados, con medias alrededor del 10, 11 y 12, y ratios de uno o dos puntos.

En cuanto al uso de vídeo, USA Today vuelve a destacar como el digital que hace mayor uso de este recurso. Con una media de 15,69 incursiones de vídeo, su media triplica a The Telegraph y Clarín (5,55 y 4,25 respectivamente), y septuplica a Le Monde $(2,22)$. Mucho menor es el uso de audio e infografías, con medias y ratios muy alejadas de otros recursos multimedia como el vídeo o las imágenes. En este sentido, sólo es reseñable la media de 1,41 infografías de Le Monde, mientras que los otros periódicos no alcanzan el punto entero.

El audio es el gran perjudicado en los resultados de este estudio, pues en los 51 días analizados ni Le Monde ni The Telegraph incrustaron piezas de audio en sus noticias principales. En el caso de los otros periódicos su incursión fue residual. Se confirma, pues, la hipótesis H3: a pesar de tratarse de medios digitales, los recursos que más utilizan son también los más utilizados en la prensa tradicional: texto y fotografía. 
El análisis de los comentarios revela un uso muy dispar de esta herramienta según el periódico que se observe. Así, la media de comentarios diarios en The Telegraph $(1542,49)$ es veintiuna veces mayor que la de Le Monde $(72,39)$. En medio se sitúa Clarín, con 360,51 comentarios de media, y USA Today con 133,92.

El número de entrevistas se revela poco influyente. En este sentido, la media de entrevistas es menor a 1 en todos los periódicos analizados, demostrando así una importante carencia de entrevistas en los digitales.

Sin embargo, sí se disponen de manera más interesante las medias referentes a la cantidad de anuncios en la página principal. Con cifras muy similares, Le Monde y Clarín tienen 11,14 y 10,84 respectivamente, mientras que USA Today y The Telegraph tienen 0,67 y 2,16. Cabe reseñar que estos dos últimos periódicos tienen más anuncios una vez se entra dentro del enlace de la noticia, y que apuestan por mantener más limpia su homepage.

Tabla 4: Cantidad de elementos interactivos y de entrevistas online

\begin{tabular}{|c|c|c|c|c|}
\hline & Le Monde & USA Today & Clarín & The Telegraph \\
\hline Total & $\begin{array}{c}51 \\
\mathbf{a}\end{array}$ & $\begin{array}{l}\text { 5l } \\
\text { b }\end{array}$ & $\begin{array}{c}51 \\
\mathrm{c}\end{array}$ & $\begin{array}{l}5 l \\
d\end{array}$ \\
\hline \multicolumn{5}{|c|}{ Noticias de la página principal } \\
\hline Media & $12,06 \mathrm{bd}$ & 10,33 & 26,67 abd & $10,92 \mathrm{~b}$ \\
\hline \multicolumn{5}{|c|}{$N^{\circ}$ Comentarios } \\
\hline Media & 72,39 & 133,92 a & 360,51 ab & 1542,49 abc \\
\hline Ratio & 6,00 & 12,96 & 13,52 & 141,23 \\
\hline \multicolumn{5}{|c|}{$N^{o}$ entrevistas online } \\
\hline Media & 0,49 bcd & 0,02 & $0,27 \mathrm{~b}$ & $0,12 \mathrm{~b}$ \\
\hline Ratio & 0,04 & 0,00 & 0,01 & 0,01 \\
\hline \multicolumn{5}{|c|}{$N^{o}$ anuncios página principal } \\
\hline Media & 11,49 bd & 0,67 & $10,84 \mathrm{bd}$ & $2,16 \mathrm{~b}$ \\
\hline
\end{tabular}

Las letras indican diferencias estadísticamente significativas al 95\% de confianza Fuente: elaboración propia

\subsection{Conclusión}

En cuanto a la hipertextualidad, Clarín es la cabecera con un mayor número de noticias en su homepage entre las que han sido objeto de estudio, lo cual denota un excelente aprovechamiento de su página principal. Su número de enlaces dentro de las noticias es equiparable a The Telegraph, pero se ve ampliamente superado por Le Monde. Creemos que, con la gran cantidad de noticias que Clarín genera en su página principal, sería muy conveniente apostar por un mayor uso de enlaces dentro de sus 
noticias, ya que así multiplicarían sus capacidades de SEO y SEM. Sirva esta conclusión también para el resto de medios digitales existentes. Cabe destacar también de la hipertextualidad que los enlaces internos son los más utilizados, creando así una cierta endogamia a no salir nunca del periódico o de las páginas colaboradoras del periódico. Asimismo, los enlaces científicos son los grandes perjudicados, al tener una media diaria inferior a uno. En un momento de sobreinformación como el actual, los enlaces científicos deberían ser mucho más recurrentes en los medios digitales, pues añadirían valor y certeza a la información. En lo que atañe al uso de elementos multimedia observamos, como sucedió al investigar las cabeceras españolas, que la prensa digital ha heredado el uso masivo de texto y foto de la prensa tradicional, dejando muy poco lugar al uso del vídeo, el audio, y las infografías. Creemos que este factor no ayuda en absoluto a la valoración de la experiencia en línea que tiene el usuario consumidor de información.

Asimismo, remarcamos el hecho de que los medios digitales tienen a su disposición las herramientas necesarias para realizar noticias con más multimedia, y que si deciden no hacer uso de estas herramientas es muy posible que se pierda a la audiencia. En cuanto a los elementos interactivos se refiere, observamos un uso muy dispar en los comentarios según el periódico analizado. Cabe destacar los más de mil comentarios de media que alcanza el inglés The Telegraph. Cabe destacar también que todas las hipótesis de la investigación fueron verificadas: (1) el número de noticias no es correlativo al número de enlaces, (2) escasean los enlaces de tipo recomendado y científico, (3) el texto y la fotografía siguen predominando ante el vídeo, el audio y la infografía, y (4) el número de noticias no es correlativo al número de comentarios. Por eso es tan necesario potenciar el uso de todos los recursos que tenemos a nuestro alcance para conseguir una prensa digital de calidad ofreciendo al lector un producto con tanto valor añadido que la información que pueda conseguir libremente no le satisfaga. Y para potenciarlo es precisa una tarea desde la perspectiva educativa, en las facultades de Ciencias de la Comunicación y, como ocurre con la emprendeduría, en estadios anteriores.

\subsection{Referencias bibliográficas}

BACHMANN, Ingrid; HARLOW, Summer (2012). Interactividad y multimedialidad en periódicos latinoamericanos: avances en una transición incompleta. En: Cuadernos de Información, 30, 41-52.

BERIAIN, Ana; FONDEVILA, Joan Francesc; GARCÍA, Alex (2012). Patrones de conducta en Facebook. estudio de caso de una simulación. En ALCUDIA, Mario; LEGORBURU, José María; BARCELÓ, Teresa (eds.): Convergencia de medios. Nuevos desafios para una comunicación global. Madrid: CEU Ediciones, 311-334.

CASTELLANOS DÍAZ, Juliana (2011). De lo impreso a lo digital la migración de los 
periódicos impresos de América Latina a los entornos digitales. En: Razón y Palabra, $77,2$.

DEUZE, Mark (2003). The web and its journalisms: considering the consequences of different types of newsmedia online. En: New Media \& Society, 5(2), 203-230.

DÍAZ NOCI, Javier (2004). Los géneros ciberperiodísticos: una aproximación teórica a los cibertextos, sus elementos y su tipología.

[http://www.ufrgs.br/limc/participativo/pdf/generos.pdf] 30-04-2013.

ENGEBRESTEN, Martin (2006). Shallow and static or deep and dynamic? Studying the state of online journalism in Scandinavia. En: Nordicom review, 27(1), 3-16.

FONDEVILA, Joan Francesc (2009a). Adaptació dels gèneres periodístics al periodisme digital: estudi empíric comparatiu. En: Trípodos. Extra 2009-V Congrés Internacional Comunicació i realitat, La metamorfosi de l'espai mediàtic. Barcelona: Universitat Ramon Llull, 657-666.

FONDEVILA, Joan Francesc (2009b). Relación entre multimedialidad, hipertextualidad e interactividad en la prensa digital española: análisis empírico. Madrid (UCM): I Congreso Internacional "Sociedad Digital".

FONDEVILA, Joan Francesc (2010a). El cloud journalism: un nuevo concepto de producción para el periodismo del siglo XXI. En: Observatorio (OBS*) Journal, 4(1), 19-35.

FONDEVILA, Joan Francesc (2010b). Uso de la hipertextualidad en la prensa digital en Cataluña y en España. En: SABÉS, Fernando; VERÓN, José Juan (eds.). El periodismo digital desde la perspectiva de la investigación universitaria. XI Congreso de Periodismo Digital de Huesca-2010. Huesca: Asociación de la Prensa de Aragón, 183199.

FONDEVILA, Joan Francesc (2011). Aplicación semántica de la hipertextualidad en la prensa digital en España. En: SABÉS, Fernando; VERÓN, José Juan (eds.). La investigación en periodismo digital. Algunos trabajos desde el ámbito universitario. XII Congreso de Periodismo Digital de Huesca-2011. Huesca: Asociación de la Prensa de Aragón, 169-180.

FONDEVILA, Joan Francesc, SIERRA, Javier, DEL OLMO, Josep Lluís (2011). New communicative markets, new business models in the digital press. En: Trípodos. Extra 2011-VI International Conference on Communication and Reality-Life without Media, Universitat Ramon Llull), 301-310.

FONDEVILA, Joan Francesc y SEGURA, Herlaynne. (2012). Hipertextuality in digital journalism in Colombia. En: Hipertext.net. Anuario Académico sobre Documentación Digital y Comunicación Interactiva (UPF-Digidoc), 10.

FONDEVILA, Joan Francesc y BERIAIN, Ana (2012): La interactividad en medios sociales: un estudio de caso. En: Revista Internacional de Ciencias Sociales Interdisciplinares, 1(2), 25-44. 
FONDEVILA, Joan Francesc; BERIAIN, Ana; DEL OLMO, Josep Lluís (2013). "Hipertexto, multimedia e interactividad: comparativa empírica en el periodismo digital español", en Zilles, K.; Cuenca J.; Rom J. (eds.): Breaking the Media Value Chain. Barcelona: Universitat Ramon Llull, 41- 50.

GOLDENBERG, Sergio (2005). La interactividad: el desafío pendiente del periodismo online. En: Cuadernos de Información, 18.

IVARS, Begoña (2012). Canales alternativos de acceso a la prensa española en internet: la noticia fuera del periódico. En: El profesional de la información, 21(4), 396-400.

LARRONDO, Ainara (2009). La metamorfosis del reportaje en el ciberperiodismo: concepto y caracterización de un nuevo modelo narrativo. En: Comunicación y Sociedad, XXII(2), 59-88.

LEVINSON, Paul (1997). The soft edge: a natural history and future of the information revolution. New York: Routledge.

MCNAIR, Brian. (1998). The sociology of journalism. London: Oxford University Press.

MERRIT, Davis, McCombs, Maxwell (2004). The Two W's of Journalism: The Why and What of Public Affairs Reporting. Mahwah, NJ: Lawrence Erlbaum.

OBLAK, Tanja (2005). The lack of interactivity and hypertextuality in online media. En: Gazette: the International Journal for Communication Studies, 67(1), 87-106.

PERELLÓ, Marc, "El cambio en la relación Sociedad - Medios en los siglo XX y XXI", en Actas - IV Congreso Internacional Latina de Comunicación Social - 2012, en línea: <http://www.revistalatinacs.org/12SLCS/2012_actas/093_Perello.pdf> Consultado el 18 de noviembre de 2013.

QUANDT, Thorsten (2008). (No) news on the World Wide Web? A comparative content analysis of online news in Europe and the United States. En: Journalism Studies, 9(5), 717-738.

ROJO, Pedro Antonio (2006). Prensa y convergencia tecnológica: Claves para la definición de un nuevo modelo de negocio periodístico en la Era Digital. En: Zer Revista de estudios de comunicación = Komunikazio ikasketen aldizkaria, 20, 411-424.

SALAVERRÍA, Ramón (2005). Cibermedios. El impacto de Internet en los medios de comunicación en España. Sevilla: Comunicación Social Ediciones y Publicaciones.

SCHULZT, Tanjev (1999). Interactive Options in Online Journalism: A Content Analysis of 100 U. S. Newspapers. En: Journal of Computer Mediated Communication, 5(1). 


\title{
d]
}

\section{Polarización mediática vs Polarización en las redes-sociales}

\section{Estudio de los perfiles de El-País y El-Mundo en Twitter*}

Javier Bustos Díaz

Universidad de Málaga

javibustos_90@hotmail.es

\author{
*Ponencia presentada en el V Congreso \\ Internacional Latina de Comunicación Social \\ y recogido en sus actas. \\ Universidad de La Laguna, diciembre 2013. \\ Reproducido con autorización \\ de los organizadores y del autor.
}

\subsection{Introducción}

Hallin y Mancini (2004) definen el sistema de medios español como pluralismo polarizado. Sus principales características son bajas tiradas de prensa, un alto nivel de paralelismo político, bajo nivel de profesionalización, una fuerte intervención estatal en el sistema mediático, un proceso de democratización tardía y una transición rápida, además de menor desarrollo de la autoridad racional-legal y un sistema pluralista organizado ¿se traslada este fenómeno a las redes sociales?

Algunos expertos, como Gelman, A. (2008) o Garret (2009) plantean que la polarización ideológica de los medios de comunicación tradicionales es una condición constantemente anunciada y evidenciada, y recuerdan que algunos consumidores tienen una preferencia significativa por los medios de comunicación afines, y que utilizan las herramientas sociales de internet para buscar aquellos con similares puntos de vista.

Esta afirmación, junto al trabajo presentado por Golbeck y Hansen (2010) para comprender las preferencias políticas de las audiencias de diferentes medios de comunicación en Twitter, nos hace pensar que este modelo se replica y que ocurre lo mismo tanto en el mundo off-line como en el mundo on-line, y unido al sondeo 
realizado por el PewResearch Center Internet and American LifeProject plantea las siguientes cuestiones ¿ocurre de igual forma en España? ¿Se traslada la polarización o se acentúa? ¿Cuáles son los elementos comunes y las diferencias con respecto a otros países? Este trabajo pretende dar respuesta a estas y otras preguntas, partiendo del análisis de los perfiles en Twitter de varios medios de comunicación en España, apoyándose en el estudio del caso: el debate del estado de la nación.

\subsection{Medios de comunicación}

Ramón Salaverría (2005), describe un cibermedio como "aquel emisor de contenidos que tiene voluntad de mediación entre hechos y públicos, utiliza fundamentalmente criterios y técnicas periodísticas, usa el lenguaje multimedia y del hipertextual, se actualiza y se publica en la red Internet”.

La conversión de internet en la principal puerta de acceso al conocimiento, a la información y al entretenimiento despierta una enorme casacada de interrogantes sobre la función y el camino de seguir por los medios tradicionales, cuyos contenidos compiten con otros nuevos sistemas de información (Freire Campos: 2008).

Timoteo (2008) enciende un semáforo rojo sobre el nuevo contexto de las relaciones de los medios con sus públicos: "Los medios pasan de ser una oportunidad a un problema. Las relaciones con los medios se llenan de desconfianza y competencia". ¿Por qué depender de los medios para comunicarse cuando las nuevas tecnologías y herramientas de conexión de internet de todos con todos ya lo permiten?

Las nociones de conocimiento, información, convergencia y red social tienen varios siglos de historia. Su genealogía moderna arranca de la crisis de la sociedad medieval europea y del despertar cultural del Renacimiento. Primero es el concepto de sociedad del conocimiento. Las necesidades de ilustración y comunicación de la sociedad moderna empujan, a la vez, hacia la convergencia y el establecimiento de redes (Freire Campos: 2008).

En el último cuarto de siglo XX la convergencia es empleada para explicar sincrética y pragmáticamente la confluencia de las tecnologías de la información con las redes de telecomunicaciones y los contenidos que circulan por ellas. Pero aunque la fuerza o el empuje causal de la convergencia sean de carácter tecno informacional, sus consecuencias y efectos son económicos y sociales. Primero es la convergencia tecnotrónica, luego la telemática y casi simultánea la digital. Digitalizar una información es codificarla en dígitos, convertirla en número, para poder manejarla de forma más eficaz y compleja. (Freire Campos, 2008).

Desde su aparición a mediados de la década de los 90 del siglo pasado, los cibermedios han ido asentándose, buscando su propio modelo de negocio y su propia voz en el conjunto de los medios de comunicación. La activación del llamado capital social a través de los medios de redes sociales, como Facebook o Twitter, da como resultado 
modificaciones en la conducta de las personas que los utilizan (García, García \& Varona: 2012: 16).

Para explicar este efecto de las redes sociales en las personas, los investigadores hablan de dos causas. Por un lado, explican, en la línea de la teoría de los Two Stpes (Lazarsfeld, Berelson y Gaudet: 1962, Lazarsfeld y Kaltz: 1979), que el hecho de que la información en las redes sociales sea filtrada por amigos o conocidos influyentes hace que los usuarios la reciban con mayor interés, por lo que el mensaje cala más profundamente. Por otro lado, las propias herramientas de las redes sociales, que permiten debatir 'in situ' la información, tanto con desconocidos como con el propio círculo de amistades, estimulan el efecto de la información. Los mismos mecanismos permiten corregir, contrastar y, en ocasiones, desmentir esa información de una forma rápida y eficaz, al alcance del usuario (García, García \& Varona: 2012: 16).

Tanto ha sido así que, ya en 2010, José Romero aseguraba refiriéndose a las redes sociales que: "Junto a otros fenómenos de la web 2.0, como los blogs o las wikis, han participado decisivamente en el cambio que atraviesa el periodismo a nivel internacional y que obliga a muchas empresas a modificar sus patrones de producción. La idea de los medios convencionales - prensa, radio o televisión- como únicos canales habilitados para transmitir información ha quedado obsoleta y ha derivado a una forma de intercomunicación descentralizada, multidireccional e interactiva. En ello han desempeñado un papel fundamental espacios como Facebook, Twitter o YouTube, cuyos contenidos escapan a veces a los controles institucionales al proponer un intercambio de información que no se planteaba anteriormente en los medios tradicionales".

Dos fuentes importantes de competitividad de las redes frente a los medios tradicionales abiertos de difusión generalista continua (radio, televisión e internet) son la identificación de la accesibilidad de los usuarios o receptores y su posible explotación publicitaria. La accesibilidad a las redes exige el registro de entre un mínimo de cuatro a 17 datos identificativos de cada usuario: dirección, nombre, apellidos, fecha de nacimiento, sexo, lugar de residencia, etc (Freire Campos: 2008).

El grupo de redes informativas pone en práctica su concepción de la participación a través de la posibilidad de suministrar, ofrecer, nutrir, comentar y votar las noticias. Es una agenda informativa creada, organizada, valorada y comentada por los propios usuarios de la red que introducen o retiran noticias según sus propios criterios. La diferencia, frente a un medio tradicional de comunicación, radica en el tratamiento profesional de la información: estándares profesionales, diversidad de fuentes, preparación, tiempo de dedicación, contraste, contextualización, códigos y responsabilidad social (Freire Campos: 2008).

Las nuevas redes se apropian de aspectos de los medios anteriores pero éstos aún no han terminado de reaccionar, aunque muchos de ellos están en la tarea.Casi todos los periódicos han incorporado a sus menús informativos la oferta de blogs colaborativos y comunidad de foros, debates o chats de conversación participativa. También es 
creciente la aportación de podcasting, con archivos sonoros y de imágenes para su descarga y distribución mediante la suscripción sindicada. Sin embargo, es todo lo contrario en la creación de rankings de noticias y weblogs, fenómenos muy usados y participados en otros cibermedios (Freire Campos: 2008).

El periodista y consultor de medios, Francis Pisani, escribió en Nieman Reports que "el cambio comienza en la periferia. Es allí donde la gente prueba nuevas prácticas. Es también donde su cultura emergente se está formando, una cultura en la cual ellos miran los medios desde una perspectiva diferente. Y así también el nuevo pensamiento de los periodistas necesita comenzar en la periferia, donde el cambio viene rápidamente entre la generación de usuarios más jóvenes, y mucho más lentamente para nosotros. Los lectores potenciales del mañana están usando la web en formas que difícilmente podemos imaginar, y si deseamos seguir siendo relevantes para ellos, necesitamos entender cómo. Sin embargo, las organizaciones periodísticas han sido demasiado lentas para notar el movimiento en lugar que están lejos de lo que ha sido su centro" (Flores Vivar: 2009: 77).

Por el momento las redes son sistemas de comunicación social básicos, fundamentados tanto en la filosofía de la afiliación y la participación como en la economía de la colaboración y la atención. Pero que, sin embargo, se han convertido en el principal punto de mira estratégico de todos los grandes grupos de comunicación durante los últimos años: News Corporation de Murdoch compraba MySpace en 2005 por 850 millones de dólares; Microsoft pagaba 240 millones por una participación de Facebook, valorada en 15.000 millones, en octubre de 2007; y AOL, filial de Internet de Time Warner, adquiría Bebo por 850 millones de euros en marzo de 2008. El de las redes es un negocio del que se lucra principalmente el operador de la plataforma. El usuario paga el acceso con sus datos personales (perfil de usuario), produce gratis (colabora enviando fotos y vídeos) y genera audiencia para la venta de publicidad. Es, por lo tanto, un triple pago: economía de la afiliación, economía de la colaboración y economía de la atención (Freire Campos: 2008).

Tan importante es la audiencia que Jay Rosen, profesor de periodismo de la Universidad de Nueva York y autor del blog Press Think, ha acuñado el concepto "la gente antiguamente conocida como la audiencia”.

Este reconocimiento del cambio fundamental en la manera cómo se reciben los mensajes de las organizaciones de medios tradicionales puede poner en entre-dicho la lección que la mayoría de nosotros aprendimos el primer día de clase en la facultad de periodismo: Nosotros enviamos, ellos reciben. Ese tipo de paradigma se ha acabado (o le queda muy poco tiempo de vida). El profesor de la Universidad de Texas, Rosental C. Alves, considera que la nueva audiencia se basa en el egocentrismo. Concretamente, en el yocentrismo (yo accedo a las noticias, en el momento que yo quiera, las noticias que yo quiera y como quiera (Flores Vivar: 2009: 78).

Las redes son un nuevo y atractivo canal que las marcas desean utilizar para reactivar su alicaído branding: escuchar, segmentar, hablar, conversar, movilizar, ayudar e 
involucrar a los posibles clientes para convertirlos en sus usuarios fieles. Claro que si la estrategia es equivocada el efecto boomerang será nefasto. Las marcas piensan que Internet y la web 2.0 les ayudarán a potenciar su experiencia comercial en un contexto más participativo y proactivo. Es la filosofía de la Web 2.0, convertida en espacio social de comunicación entre distintos usuarios e intervinientes, que aprovechan las herramientas informáticas de producción y gestión de contenidos para interactuar e intercambiar contenidos (Freire Campos: 2008).

Las redes sociales escogen a los medios tradicionales como fuentes de información, bien a través de las aportaciones que los propios usuarios realizan para fundamentar sus comentarios y participaciones o bien mediante enlaces generados por estas nuevas plataformas de contenidos. Los medios, sin embargo, son mucho más cautos, parcos y preventivos en la apertura de enlaces exteriores. Dicho de otra manera: las redes se aprovechan directa o indirectamente del valor informativo generado por los medios mientras que el uso que hacen éstos de la llamada Web 2.0 o Web social es mucho más conservador y proteccionista con respecto a su propio modelo (Freire Campos: 2008).

Las redes sociales, como plataformas de distribución de contenidos que son, generan su actividad y buena parte de su flujo de contenidos en base a la economía de la colaboración y contraprestación gratuita de los usuarios, sin apenas filtrado ni selección. Los medios tradicionales, por su parte, seleccionan, evalúan y construyen la pauta informativa en base a los criterios jerarquizados de la organización informativa profesional (Freire Campos: 2008).

Los medios de comunicación, con presencia en Internet, deben desarrollar (algunos ya lo hace) una serie de estrategias promocionales dentro de estas redes. Por citar algunos ejemplos, The New York Times y The Washinton Post en Estados Unidos y el diario El País y El Mundo en España, son algunos de los medios periodísticos que realizan este tipo de iniciativas publicitarias. El objetivo sigue siendo el mismo: tener presencia en la Red dentro de estos segmentos de población que al fin y al cabo, son audiencia. En este sentido, la tecnología no hace más que reforzar o potenciar la estrategia propia de las redes informales, que siempre han funcionado para estas actividades. De ahí que, la integración a las plataformas de las redes sociales virtuales de los recursos de comunicación móvil (PDA, teléfonos móviles, etc.) ha conseguido una mayor omnipresencia y han aumentado la facilidad y la intensidad de la conectividad. Así, servicios como Twitter o Jaiku ayudan a los miembros de las redes informales a reafirmar su presencia y su identidad (Flores Vivar: 2009: 77).

La comparación de uno y otro modelo no es enfatizar a uno ni minusvalorar al otro. Ambos tienen aspectos interesantes por una parte y cuestionables por otra. La comparación pretende observar la evolución de uno y otro modelo, ver sus interacciones y cómo se tratan de plasmar algunas de sus características competitivas. Sin olvidarnos tampoco -otra aclaración que no puede quedar olvidada- que el control empresarial de uno y otro modelo crece de forma notable a través de la concentración de la propiedad mediática. Son las mismas grandes corporaciones (News Corp., Google, Microsoft) las que están avanzando en el control de la propiedad de los 
medios tradicionales y de las redes sociales (Freire Campos: 2008).

El análisis de Pisani, recogido en el libro Journalism 2.0 de Mark Briggs, sobre el modelo del periodismo que nos espera, de por sí, muy ilustrativo. Otros expertos como Jeff Jarvis, profesor y autor del influyente blog Buzz Machine, en la misma línea que Pisani, afirma que el modelo de los "periódicos de 2020 necesitarán agregar y que les agreguen. Señalarán otros que los hacen bien y se ahorrarán el gasto de hacerlo ellos mismos. Harán lo que mejor sepan hacer y lo que otros enlacen a ellos" (Flores Vivar: 2009).

\subsection{Datos extraídos del debate del estado de la nación}

A lo largo del apartado anterior se han puesto de relevancia datos que indican un cambio por parte de los medios: webs, blogs, redes sociales. Pero chan cambiado algo los medios? ¿Qué medios participan más en el debate en redes? Tras el análisis de 1.000 tweets del debate del estado de la nación que tuvo lugar entre el 20 y el 21 de febrero de 2013, se puede decir que los medios no se han actualizado.

Pero primeramente se mostrará que medios han participado más y que podemos resaltar de este apartado:

Gráfico 1. Participación de los medios de comunicación en el debate del estado de la nación

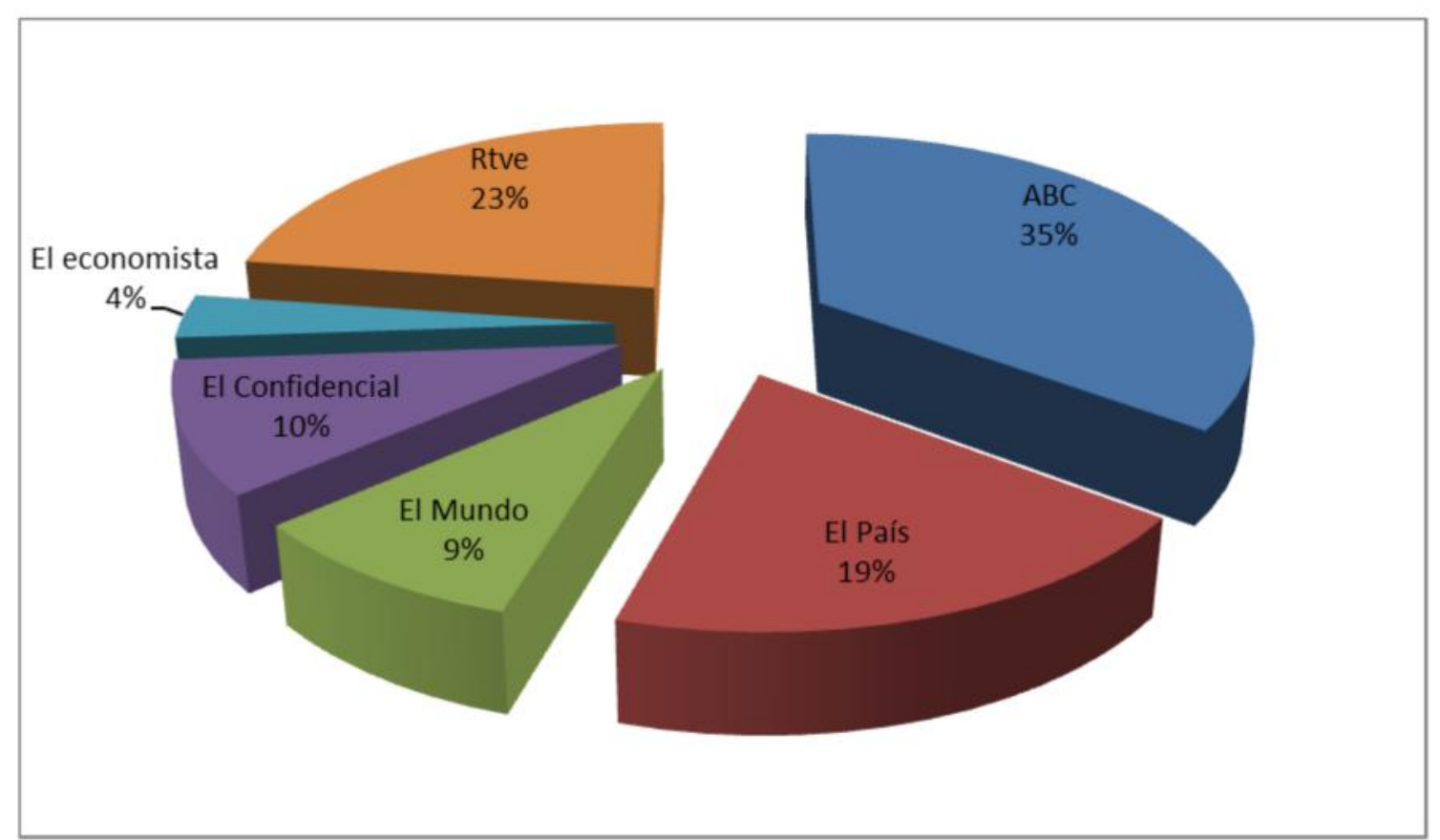

Gráfico de elaboración propia 
Como se puede observar, Radio Televisión Española y $\mathrm{ABC}$ son los que más participación tienen en el debate, o al menos, los que más publican tweets con el hashtag del mismo.

Además, no muestran signos de polarización en lo referente al tipo de tweets que emiten, es decir, en la mayoría de los casos se hacen las clásicas citas literales de las intervenciones o se da paso a un link que enlaza con la web del medio y muestra una noticia, ya sea vídeo, texto o imagen, que cuenta que está sucediendo durante el debate pero se aleja, en un primer momento de forma parte del mismo.

Ocurre algo muy diferente si analizamos sus seguidores, es decir, una de las ventajas estar en redes sociales como en Twitter, es que no hay que pagar coste por la información, es más, puedes seguir a todos los medios de información general con coste $0 €$.

Sin embargo, el modelo español de prensa, donde El País y El Mundo son los líderes de la información general, se traslada a las redes sociales.

Es decir, el bipartidismo mediático de la información general (esto no quiere decir que El País y El Mundo sean los diarios más leídos en España, pero si los diarios de información general con más lectores y por encima de ellos está el Diario Marca) se extrapola a las rede sociales, como muestra la siguiente gráfica:

Gráfico 2. Difusión diarios españoles según OJD

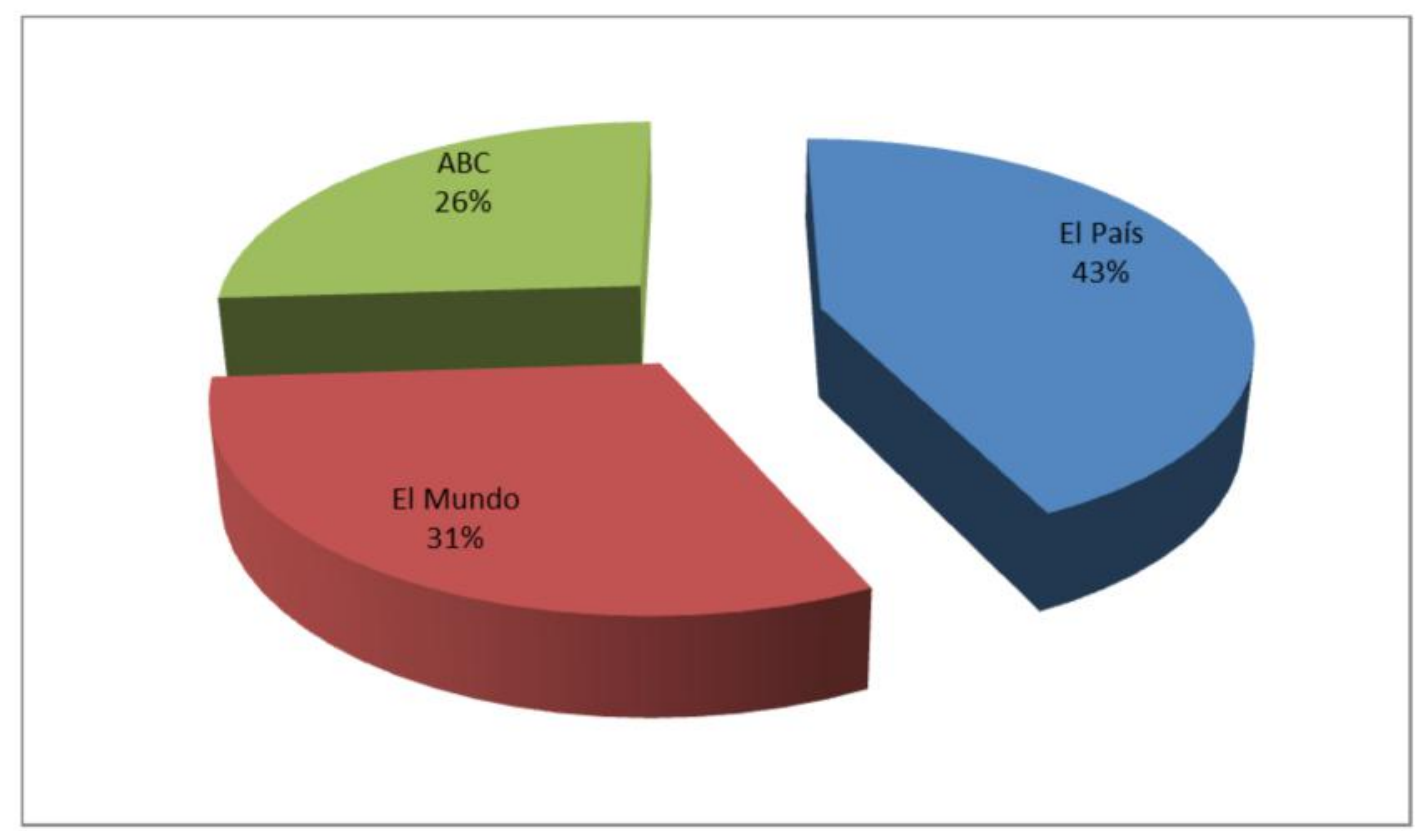

Gráfico de elaboración propia

Se desprende de los datos que existe una relación causa efecto entre los seguidores de un medio de comunicación en el mundo off-line y el mundo on-line. Esto es, según la OJD los medios que analizamos que se estudian en este artículo, ABC, El País y El 
Mundo se reparten la tirada de la siguiente forma un 26\% para ABC, 31\% para El Mundo y a la cabeza el País con un 43\%, en Twitter la escala queda clasificación queda establecida de forma similar: 64\% para el País frente a un 29\% y 7\% de El Mundo y $\mathrm{ABC}$ respectivamente, como muestra la siguiente gráfica:

Gráfico 3. Números de seguidores por periódico en Twitter

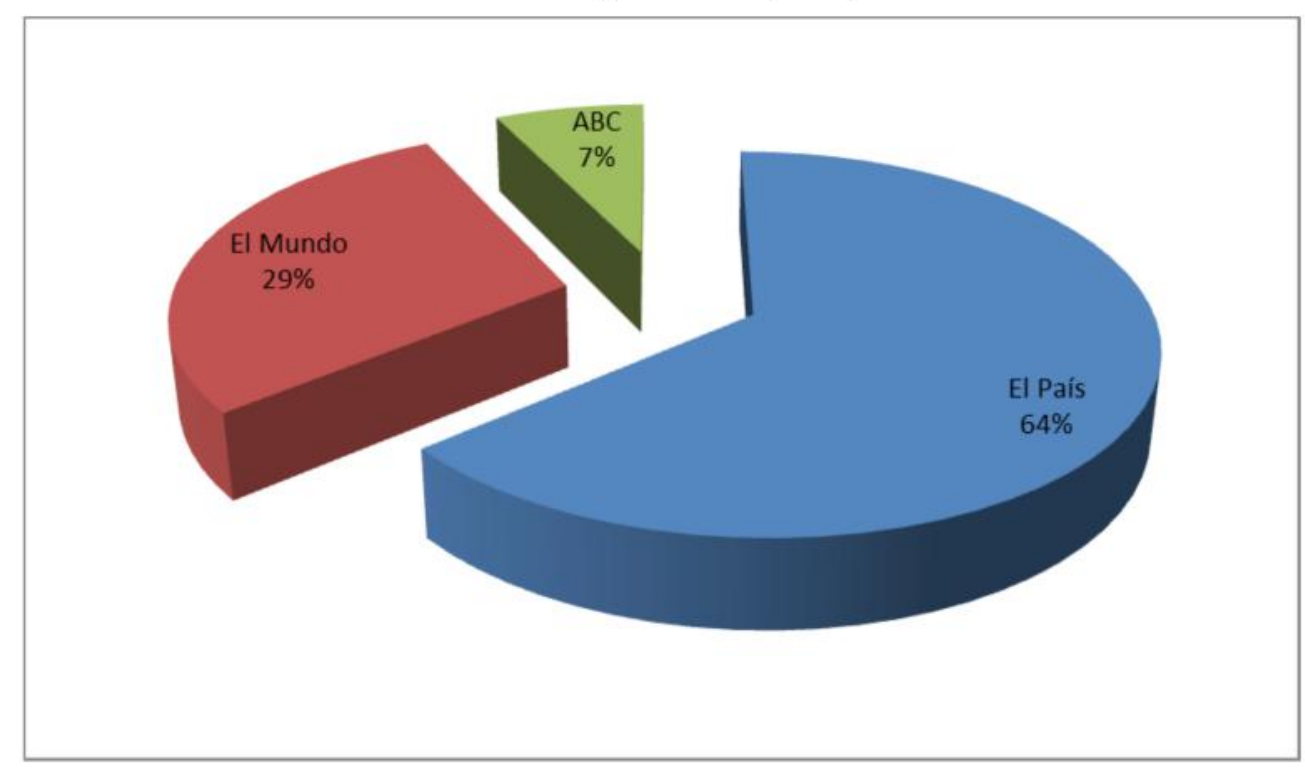

Gráfico de elaboración propia

Además de esto, existe una relación inversamente proporcional entre el número de seguidores de un periódico en Twitter y el de sus directores:

Gráfico 4. Número de seguidores de los Directores de Medios de Comunicación

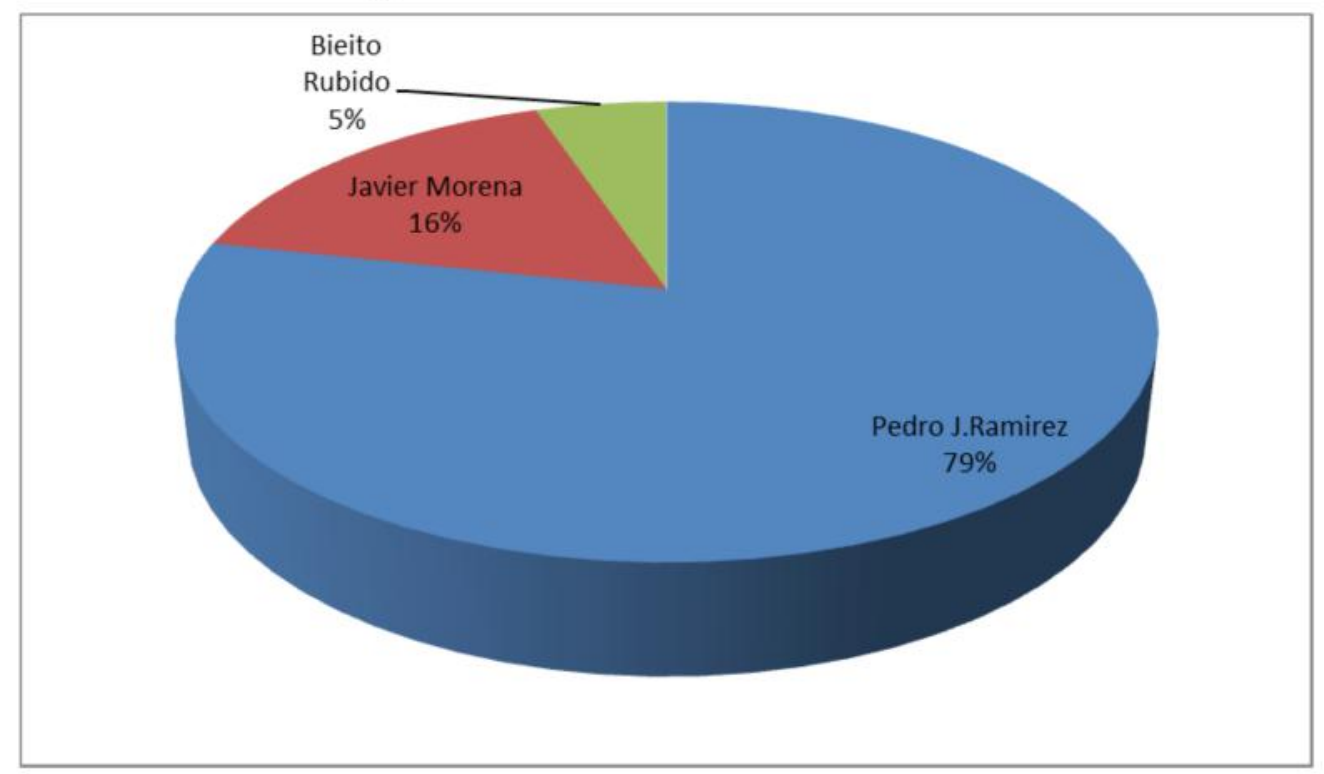

Gráfico de elaboración propia 
A un priori, puede parecer algo anecdótico pero, puede que el paradigma de la comunicación social este cambiando y ahora, los ciudadanos busquen de las redes una opinión consagrada, algo vaya más allá de la información objetiva y cree debata como pueden ser la opinión de Pedro J., Javier Barber u otros muchos buenos periodistas de nuestro país.

\subsection{Conclusiones}

De lo planteado en el título de este artículo Polarización mediática vs. Polarización en las redes sociales. Estudio de los perfiles de El País y El Mundo en Twitter, se puede decir que existe polarización pero no a todos los niveles, en lo que a Twitter se refiere.

Como se ha mostrado en las gráficas, existe una tendencia que se está extrapolando el liderato de los principales medios de comunicación en España a la red social Twitter, hecho que, por ende, replica el modelo pluralista polarizado que se da en el mundo off-line al mundo on-line.

Es muy importante resaltar que no se ven síntomas de discursos polarizados, o no al menos en los perfiles estudiados,

Por otra parte, existe una tendencia a que algunos "iconos" del periodismo tengan más seguidores que sus medios, no solo por los directores, de los medios, sino que determinados periodistas y líderes de opinión atraen más a los usuarios que los propios medios.

Esto puede ser síntoma de un cambio en la tendencia, del estar informado al estar interesado en algo que va un poco más allá de los 140 caracteres.

Por lo tanto, creo que es pronto para hablar de una completa polarización de las redes sociales pero, actualmente existe un inicio de dicho fenómeno a tener muy en cuenta en la red social Twitter.

\subsection{Bibliografía}

BEALE, A. (2012). De los medios de comunicación estatales a las redes mundiales. En M. DE MORAGAS, La comunicación: de los orígines a internet (págs. 157-210). Barcelona: Gedisa, S.A.

BERROCAL, S., CAMPOS DOMÍNGUEZ, E., \& REDONDO GARCÍA, M. (2012). "El "infoentretenimiento" político en Internet: La presencia de cinco líderes europeos en YouTube". RIPS, 11(4), 107-131.

BOWMAN, S., \& WILIS, C. (2003). We Media. How audiences are shaping the future 
of news and information. Stanford: Media Center.

FLORES VIVAR, J. M. (2009). "Nuevos modelos de comunicación, perfiles y tendencias en las redes sociales". Comunicar, 33, 73-81.

FREIRE CAMPOS, F. (2008). "Las redes sociales trastocan los modelos de los medios de comunicación tradicionales". Revista Latina de Comunicación Social, 63, 287-293.

GARCIA, A., GARCÍA, I., \& VARONA, D. (2012). "Incidencia de las redes sociales vs cibermedios, en las elecciones en España, 2011”. Enl@ce Revista Venezolana de Información, Tecnología y Conocimiento, 9(2), 11-29.

HALLIN, D., \& MANCINI, P. (2004). Comparing Media Systems.Three Models of Media and Politic. New York: Cambridge University Press.

ORIHUELA, J. L. (2011). Mundo Twitter. Barcelona: Grupo Planeta.

SAMPEDRO BLANCO, V. (2008). "Comunicación Política: Nuevos medios,nuevas audiencias, nuevos problemas". TELOS, 74.

SÁNCHEZ MEDERO, R. (2009). "La comunicación política española, ¿un modelo propio o una adaptación del modelo estadounidense?". Revista de Ciencias Sociales, 923. 


\title{
(a) \\ Obtención de una visión personal de las comunicaciones en Iberoamérica a través de la prensa digital
}

\author{
Dr. Raymond Colle \\ Ex-profesor Pontificia Universidad Católica de Chile \\ y Universidad Diego Portales \\ Santiago de Chile \\ raymondcolle@gmail.com
}

\subsection{Introducción}

¿Qué visión de la realidad de las comunicaciones en la región puede tener un particular a partir de los recursos disponibles diariamente en la web? ¿Si los acumula y organiza, qué resultados podrá obtener? Éstas fueron las preguntas que nos formulamos en 2009, optando al mismo tiempo por publicar en la web, en forma resumida, las noticias que íbamos recogiendo. Damos cuenta aquí de la experiencia en sus diversas etapas y de los principales resultados obtenidos, los que, por cierto, parecen lejos de formar un panorama coherente. Si bien un lector común puede haber visto las mismas noticias que hemos registrado es dudoso que las haya conservado. Para este estudio tuvimos, obviamente, que utilizar recursos técnicos que no están al alcance de todos, como una base de datos, un sistema de registro de la información en ésta y programas especiales de extracción de datos con fines estadísticos para poder obtener información sobre el proceso y sus resultados. Nuestra conclusión es que, aún así, el panorama es difícil de esbozar y resulta imposible comparar todas las variables. 


\subsection{Etapas}

\subsubsection{Diseño}

\subsubsection{Las tablas de datos}

Consideramos esencial partir definiendo las variables que serían conservadas en la base de datos. Ésto se basa en el análisis lógico de la estructura de la información periodística (Colle, 1992 y 2000), las reglas del diseño de bases de datos normalizadas y las necesidades futuras de análisis de los datos (ver Colle, 2002).

Seleccionamos las variables o "atributos" de las noticias en función de la estructura de estas, como mostrado en el Gráfico 1 (explicado detalladamente en Colle, 2002, pp.9799).

\section{Gráfico 1. Atributos de las noticias}

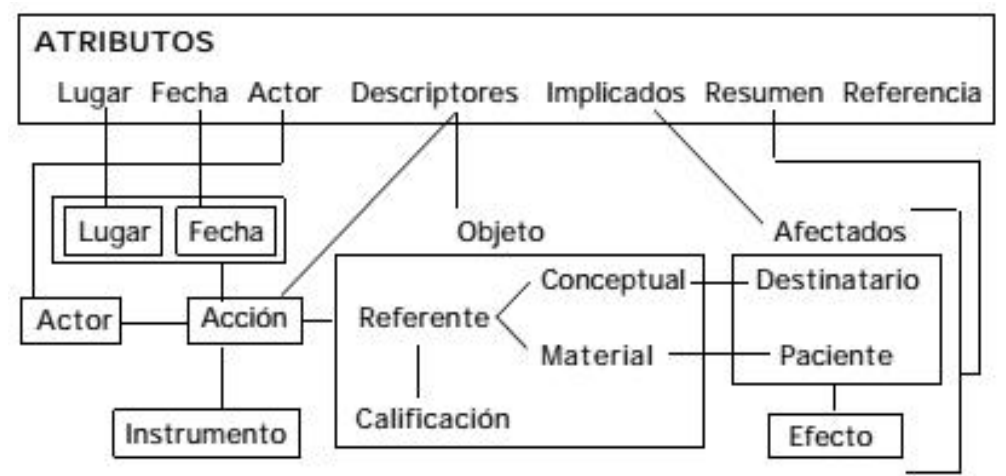

Conservamos la información básica de cada noticia mediante su título y un resumen (generalmente el lead), junto con el lugar (país), la fecha y la fuente, que dan lugar a la tabla principal de la base de datos. Registramos la temática utilizando un microteauro de 205 términos.

Actores y afectados pueden ser registrados por su nombre o por su función (o ambos). En este caso, juntamos ambos bajo el único atributo "implicados" y registramos el nombre y cargo de las personas y organismos (instituciones, empresas, etc.) solamente cuando eran suficientemente conocidas y susceptibles de aparecer en múltiples casos (La justificación de este proceder puede enontrarse en Colle, 2002, pp.104-105). En cambio registramos siempre el tipo de cargo o función de cada implicado en otra variable, utilizando una lista de autoridad de 47 términos para las personas y 120 para organismos.

Tesauro y listas de autoridades constituyen tablas anexas que han de asegurar la coherencia del conjunto, pero son también fundamentales las tablas que contienen el número ("id") de cada noticia con los descriptores asociados (hasta 3 cada vez) y con la identificación de los implicados (cuyos datos específicos se conservan en otras tablas si es el caso). Se construye así un sistema de tablas interrelacionadas según el principio 
mostrado en el Gráfico 2. (No mostramos el conjunto completo, que es mucho más complejo.)

Gráfico 2. Sistema de interrelación de tablas

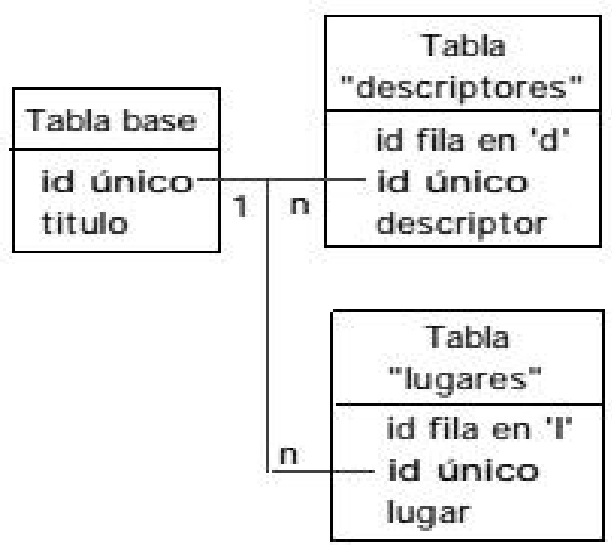

\subsubsection{La selección de las fuentes}

Habría sido evidentemente imposible revisar diariamente los sitios de los diarios de cada país de la región para averiguar si aparecía alguna noticia sobre el tema de las comunicaciones. En consecuencia, partimos con el principal diario local (El Mercurio, de Chile), un diario español (El Mundo) -ambos con secciones tecnológicas-, las revistas tecnológicas dedicadas a Internet que tenían sindicación (es decir legibles con agregadores RSS) y Google News, para luego ir agregando otras fuentes a partir de las referencias encontradas. Así, partimos en julio de 2009 con 22 fuentes para terminar en 2013 con un centenar. Utilizamos Google Reader para ver los titulares en RSS, pero al desaparecer a mediados de 2013, pasamos a G2reader. Su principal ventaja es que ofrece un sistema de filtros que permite marcar los titulares que contienen términos clave, facilitando un acceso más rápido a las noticias de interés (ver Gráfico 3).

Gráfico 3. G2reader (fragmento)

\begin{tabular}{|c|c|c|c|c|c|}
\hline 6 621eqDer & E & Marcar como leidos & Configuración de la carpeta $\nabla$ & $\nabla$ & $\Delta$ \\
\hline \multicolumn{6}{|l|}{ Suscripcones en carpetas } \\
\hline Eacionales & 321] & El Universal: México & Reviven versión sobre presencia de $\sharp 34 ; \mathrm{El}$ Chapo\# 34 ; en Argentina & $1 d$ & 口 \\
\hline $\begin{array}{l}\text { EC El Comercio - Políti.. } \\
\text { eP El Periódico - Pais }\end{array}$ & 22 & * El Universal: México & Meade se reúne con el principe heredero de Kuwait & $1 d$ & ए \\
\hline 접 El Universal: México & 108 & ElUniversal; Mëxico & Piden a SCI datos sobre programa de telecom & $2 \mathrm{~d}$ & 牙 \\
\hline $\begin{array}{l}\text { I lostiempos.com - Últ. } \\
\text { ㅁ Noticias sobre Latin... }\end{array}$ & 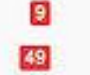 & † El Universat; México & Apoyo de maestros permitirá mejorar calidad educativa: Peña & $2 \mathrm{~d}$ & 口] \\
\hline
\end{tabular}

(Aparece con amarillo una palabra que pertenece al filtro que ingresamos) 


\subsubsection{Registro y visualización de los datos}

Diseñamos un formulario especial para ingresar todos estos datos, desagregados, en las diferentes tablas que conforman la base de datos y también un mecanismo de consulta, tanto para ver cada noticia como las asociadas a través de idénticos receptores (para observar el contexto) y para recuperar las noticias sobre la base de sus diversos atributos. En el período considerado, acumulamos 1690 noticias.

Gráfico 4. Formulario de registro

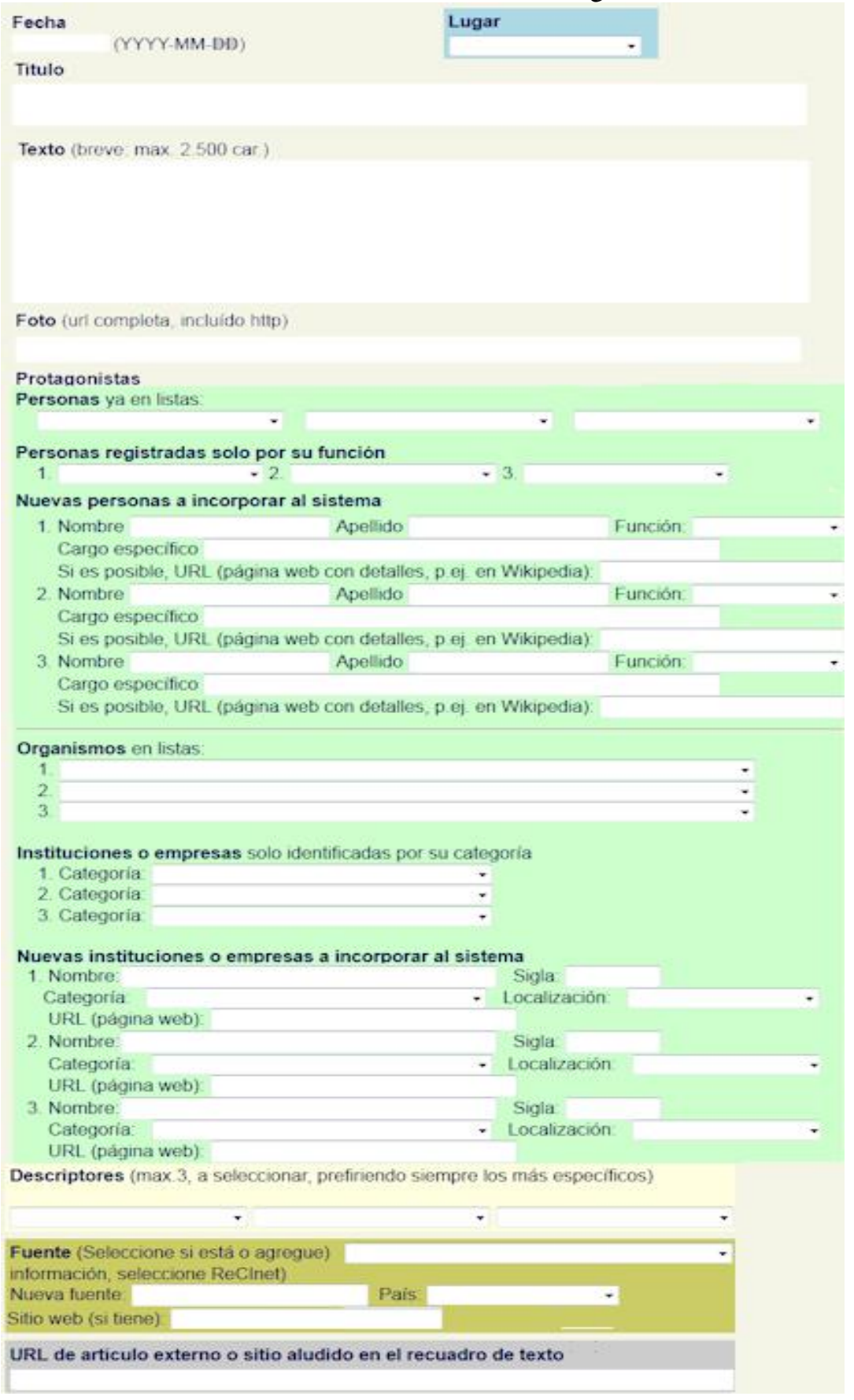


El siguiente es un ejemplo de una noticia ingresada, con sus descriptores y el contexto -asociado de acuerdo a estos últimos- que se podía observar después gracias a la programación desarrollada:

2013-12-30 - Perú - Polémica en los medios por declaraciones del presidente Ollanta Humala

El presidente Ollanta Humala finalizó ayer su última entrevista del año generando una polémica: el mandatario peruano arremetió contra el Grupo El Comercio y sus posesiones empresariales, en su mayoría organizaciones de noticias. "Es una vergüenza que en el Perú un solo grupo sea dueño de los medios de comunicación”, cuestionó Humala. "Eso es peligroso para la libertad de expresión. La libertad de expresión es un valor que no se puede monetarizar", argumentó. Y agregó una frase que causó suspicacia: "No es ilegal (la asociación). Ahorita no es ilegal".

El Instituto Prensa y Sociedad (IPYS) indica que debido a que el presidente no dijo exactamente si durante su administración se promoverá la modificación del marco legal que avaló dicha operación financiera, se necesita precisar "el alcance y la implicancia de sus declaraciones". IPYS considera que el Gobierno debe mantenerse al margen de la controversia.

Ante este escenario, la compañía de la familia Miró Quesada ha sostenido que con esta crítica mediática no se busca "recortar" el poder del grupo, sino "recortar el poder de elegir del lector". Tras las declaraciones de Ollanta Humala, el diario asegura hoy en su portada que el gobierno "lanzó una velada amenaza contra la libertad de expresión".

Implicados (Nombre y tipo):

Persona: Ollanta Humala / Político,

Organismos: Instituto de Prensa y Sociedad, El Comercio / Asociación de profesionales, Periódico,

Descriptores: Medio de comunicación, Economía, Derecho,

Fuente: Clasesdeperiodismo (Perú)

Archivo relacionado: http://https://www.youtube.com/watch?

feature=player_embedded\&v=_vhzGA2uak8\&list=UUoZSE7la7IYFCupaVogRR1A

\section{Información contextual:}

23-10-2013 Alertan que Ley de Delitos Informáticos podría afectar la libertad de expresión. A pesar de los cuestionamientos, el Ejecutivo promulgó ayer la Ley de Delitos Informáticos, que entra hoy en vigencia. (... $)^{4}$

20-10-2013 Propietarios de diarios peruanos se enfrentan en asamblea de la SIP. Durante la asamblea general de la Sociedad Interamericana de Prensa (SIP) que se realiza en Denver, Colorado, los propietarios de El Comercio y La República de Perú se enfrentaron en una discusión sobre el supuesto monopolio del mercado de diarios en el país. En agosto (...)

01-09-2013 El 78\% del mercado de diarios podría quedar en una sola mano con la compra de Epensa por El Comercio. El último 21 de agosto se produjo una operación comercial que derivaría en un radical cambio en el mercado editorial de los periódicos del Perú: el Grupo El Comercio adquirió el 54\% del Grupo Epensa. De consumarse, se produciría una (...)

En el sistema, estas noticias abreviadas tienen enlace a su ficha completa. 
10-06-2013 Inauguran Encuentro Internacional de Periodismo Cultural. Hoy se inició el II Encuentro Internacional de Periodismo Cultural en Lima. Son 25 ponencias y tres talleres en los que se abordarán temas como: "ciudadanía, política y periodismo cultural”, "crítica y periodismo cultural especializado", "redes para el desarrollo (...)

07-06-2013 Existen 97 medios de comunicación estatales. De acuerdo a la nota publicada por CONCORTV (Consejo Consultivo de Radio y Televisión), actualmente existen dentro del país 97 titulares de radio y TV estatales. (...)

14-05-2013 Invitan a presidente Humala a considerar riesgos en Acuerdo TransPacífico. En un intento de recolectar firmas para crear conciencia y enviárselas al presidente del Perú, Ollanta Humala, los activistas agrupados en torno a la Red Peruana por una Globalización con Equidad (RedGE) crearon la página NoNegociable. (...)

25-07-2012 Se promulgó ley para masificar la banda ancha en el país. El uso de Internet es "de necesidad e interés público", según una ley promulgada la semana pasada por el gobierno peruano. (...)

27-01-2012 Ollanta Humala ratifica compromiso con libertad de expresión. "Mi compromiso con la libertad de expresión es tan fuerte que me pone por encima de las pasiones que uno podría recordar y señalar, no tengo tiempo de tomar acciones arbitrarias porque bueno, durante la campaña, gran parte de la prensa nacional se puso una camiseta político partidaria e hizo campaña”, declaró el jefe de estado peruano en una reunió con empresarios en el Casino de Madrid, durante su visita a España. (...)

(Siguen unas 10 notias más, de años anteriores)

\subsubsection{Consolidación de datos}

Los contenidos de la base de datos se respaldaron semanalmente. Anualmente se extraían resultados estadísticos que se conservaban en planillas Excel.

\subsection{Análisis de lo obtenido}

\subsubsection{Localización}

Ya hemos mencionado que nuestra lista de fuentes creció cada año, lo cual explica en parte los vacíos de 2009 y 2010, pero influyen evidentemente los acontecimientos y los registros de ellos en las diversas fuentes. De modo general hemos podido recolectar más noticias en los dos últimos años, en parte gracias a mejores lectores de RSS pero también debido a los cambios ocurridos en los respectivos países. Pensamos que la columna de total de la siguiente tabla muestra al mismo tiempo cuanta atención se presta a los temas que nos interesaban en los países y medios consultados. Tomando en cuenta que el trabajo se hizo desde Chile, es claro que se han difundido más informaciones de España, México y Argentina que del propio país donde estamos. Si aparecen países de fuera de la región es debido a que la noticia era significativa para ésta.

Considerando las fuentes que aparecieron más frecuentemente (Tabla 2), también vemos que los medios españoles han sido los principales (y no por referirse a las 
mismas noticias, ya que hemos evitado siempre las repeticiones).

Tabla 1. Noticias recopiladas, por país y año

\begin{tabular}{lcccccc}
\hline Lugares & 2009 & 2010 & 2011 & 2012 & 2013 & $\mathrm{~T}$ \\
\hline España & 35 & 61 & 66 & 87 & 216 & 465 \\
Internacional & 8 & 19 & 34 & 54 & 90 & 205 \\
México & 2 & 7 & 27 & 65 & 94 & 195 \\
Argentina & 9 & 11 & 16 & 49 & 54 & 139 \\
Chile & 16 & 10 & 23 & 39 & 40 & 128 \\
Estados Unidos & 10 & 0 & 0 & 0 & 113 & 123 \\
Ecuador & 3 & 5 & 15 & 37 & 46 & 106 \\
Venezuela & 5 & 9 & 5 & 9 & 35 & 63 \\
Brasil & 3 & 5 & 0 & 13 & 30 & 51 \\
Bolivia & 0 & 4 & 3 & 18 & 15 & 40 \\
Perú & 0 & 3 & 8 & 8 & 21 & 40 \\
Internet & 5 & 0 & 0 & 5 & 29 & 39 \\
Colombia & 2 & 5 & 5 & 10 & 14 & 36 \\
Honduras & 0 & 0 & 3 & 0 & 18 & 21 \\
Gran Bretaña & 3 & 0 & 0 & 0 & 16 & 19 \\
Panamá & 0 & 1 & 2 & 4 & 4 & 11 \\
Cuba & 3 & 3 & 4 & 0 & 0 & 10 \\
Nicaragua & 0 & 2 & 2 & 0 & 5 & 9 \\
El Salvador & 0 & 0 & 0 & 3 & 3 & 6 \\
Costa Rica & 0 & 0 & 0 & 5 & 0 & 5 \\
Paraguay & 0 & 1 & 0 & 2 & 1 & 4 \\
Guatemala & 0 & 0 & 0 & 1 & 2 & 3 \\
República Dominicana & 0 & 0 & 3 & 0 & 0 & 3 \\
Uruguay & 0 & 2 & 0 & 0 & 0 & 2 \\
Puerto Rico & 0 & 0 & 0 & 0 & 1 & 1
\end{tabular}

Nota: Los datos de 2009 solo corresponden al $2^{\circ}$ semestre.

Tabla 2. Fuentes más frecuentes

\begin{tabular}{lc}
\hline Fuentes & $\%$ \\
\hline FayerWayer, Chile & $13.87 \%$ \\
Clasesdeperiodismo, Perú & $8.56 \%$ \\
El Mercurio, Chile & $8.39 \%$ \\
El Mundo, España & $5.09 \%$ \\
El Pais, España & $4.64 \%$ \\
La Nación, Argentina & $4.59 \%$ \\
Noticiasdot.com, España & $3.75 \%$ \\
El Comercio, Ecuador & $3.41 \%$ \\
El Universal, México & $3.19 \%$ \\
Revista Latina CS, España & $2.91 \%$ \\
ABC, España & $2.24 \%$ \\
ReClnet, Internet & $1.79 \%$ \\
PRinternet, España & $1.57 \%$ \\
Sinc, España & $1.40 \%$ \\
Soc.Latina de Com.Soc., España & $1.29 \%$ \\
Knight Center (U.Texas), EUU & $1.17 \%$ \\
BBC, Gran Bretaña & $1.12 \%$ \\
Los Tiempos, Bolivia & $1.12 \%$ \\
SocialMedia Today, EEUU & $1.12 \%$ \\
Ticbeat, España & $1.06 \%$
\end{tabular}


Es interesante ver cuales son los diarios que se ocupan más de lo que ocurre en otros países en nuestro campo de estudio. Junto con El Mercurio (Chile), son los diarios españoles los que más observan lo que ocurre en otros países de la región en materia de comunicaciones, como lo muestra la Tabla 3.

Tabla 3. Ubicación de la noticia, por diario

\begin{tabular}{l|c|}
\hline Diario & $\mathrm{N}^{\circ}$ Localiz. \\
\hline EI País & 16 \\
EI Mercurio & 15 \\
ABC & 11 \\
EI Mundo & 10 \\
La Nación & 8 \\
El Comercio & 8 \\
El Universal & 7 \\
Los Tiempos & 1
\end{tabular}

\subsubsection{Temática}

Si bien utilizamos un microtesauro de 205 términos -obtenido de trabajos anterioresson muchos los que no aparecieron o solo aparecieron muy pocas veces. En la Tabla 3, mostramos los más frecuentes (con una aparición superior al 1\%). Para cada noticia, se anotaban 3 descriptores temáticos, por lo que las altas frecuencias son significativas, expresión tanto del área de estudio como de lo aparecido en los medios consultados. La frecuencia más alta corresponde a 'Periodismo' con un total neto de 181, equivalente a 7,98\%. El derecho (leyes), la prensa digital y la libertad de prensa o expresión se destacan también, con más de $5 \%$.

Tabla 4. Descriptores temáticos más frecuentes

\begin{tabular}{lc} 
Descriptor & $\%$ \\
\hline Periodismo & $7.98 \%$ \\
Estadística & $7.10 \%$ \\
Derecho & $6.62 \%$ \\
E-prensa & $6.26 \%$ \\
Libertad de prensa/expresión & $5.38 \%$ \\
Política & $4.59 \%$ \\
Red social & $4.59 \%$ \\
Telecomunicación & $3.31 \%$ \\
Televisión & $3.31 \%$ \\
Internet & $2.82 \%$ \\
Sitio web & $2.78 \%$ \\
Medio de comunicación & $2.69 \%$ \\
Prensa & $2.56 \%$ \\
Periódico & $2.03 \%$ \\
E-comercio & $1.50 \%$ \\
Comercio & $1.37 \%$ \\
Delito & $1.37 \%$ \\
Tecnologías de Información & $1.37 \%$ \\
Comunicación móvil & $1.15 \%$ \\
Digital & $1.15 \%$ \\
Investigación & $1.15 \%$ \\
Economía & $1.06 \%$
\end{tabular}


Aquí es donde puede ser de particular interés ver lo que se destaca en cada país. Para ello se requiere realizar un análisis con el cruce de las variables 'lugar' y 'descriptor temático'. En la Tabla 5 incluimos la lista de países y los descriptores temáticos que aparecieron más frecuentemente asociados a las noticias de dichos países.

Tabla 5. Principales temas por país

$\begin{array}{lcccccccc} & \text { Periodismo } & \text { Estadística } & \text { Derecho } & \text { Lib.prensa } & \text { Política } & \text { Red social } \\ \text { Argentina } & 17 & 7 & 72 & 44 & 44 & 6 \\ \text { Bolivia } & 5 & 2 & 12 & 13 & 14 & 3 \\ \text { Brasil } & 8 & 5 & 13 & 13 & 8 & 6 \\ \text { Chile } & 5 & 33 & 34 & 8 & 10 & 9 \\ \text { Colombia } & 8 & 5 & 7 & 11 & 4 & 2 \\ \text { Costa Rica } & 1 & 0 & 5 & 3 & 1 & 2 \\ \text { Cuba } & 3 & 0 & 2 & 10 & 5 & 2 \\ \text { Ecuador } & 12 & 6 & 50 & 64 & 50 & 3 \\ \text { El Salvador } & 1 & 1 & 2 & 3 & 2 & 0 \\ \text { España } & 11 & 137 & 63 & 15 & 10 & 41 \\ \text { Guatemala } & 1 & 0 & 1 & 1 & 1 & 0 \\ \text { Honduras } & 5 & 1 & 12 & 12 & 4 & 0 \\ \text { México } & 41 & 24 & 42 & 29 & 24 & 7 \\ \text { Nicaragua } & 4 & 2 & 1 & 7 & 6 & 0 \\ \text { Panamá } & 4 & 1 & 3 & 6 & 2 & 0 \\ \text { Paraguay } & 1 & 0 & 0 & 2 & 2 & 0 \\ \text { Perú } & 5 & 3 & 9 & 11 & 7 & 0 \\ \text { República Dominicana } & 2 & 1 & 3 & 7 & 3 & 0 \\ \text { Uruguay } & 2 & 2 & 5 & 3 & 0 & 2 \\ \text { Venezuela } & 12 & 7 & 16 & 41 & 36 & 5 \\ & 148 & 237 & 352 & 303 & 233 & 88\end{array}$

Nota: Los totales mencionados en la tabla no corresponden a los porcentajes señalados en la tabla anterior porque no toman en cuenta noticias que no se refieren a un país específico de la región (p.ej. de reuniones internacionales).

¿Existieron cambios en los años considerados? Lo veremos aquí para los países con más de 100 noticias y solo para los temas que abordaron más frecuentemente.

En España, los temas que encontramos más frecuentemente fueron las estadísticas y el derecho. Mientras hemos obtenido progresivamente más datos estadísticos, la frecuencia de temas de derecho de las comunicaciones ha permanecido relativamente estable (Tabla 6.1).

Tabla 6.1. Temática que sobresalió en España

\begin{tabular}{l|c|c|c|c|c|}
\hline España & 2009 & 2010 & 2011 & 2012 & 2013 \\
\hline Estadística & 5 & 19 & 21 & 29 & 63 \\
Derecho & 10 & 16 & 10 & 13 & 14
\end{tabular}

De México hemos obtenido más información en los dos últimos años, en forma pareja, sobre derecho y periodismo. 
Tabla 6.2. Temática que sobresalió en México

\begin{tabular}{|l|c|c|c|c|c|}
\hline México & 2009 & 2010 & 2011 & 2012 & 2013 \\
\hline Derecho & 1 & 0 & 6 & 13 & 22 \\
Periodismo & 1 & 2 & 7 & 12 & 19
\end{tabular}

En Argentina, también hemos visto más información en los tres últimos años, especialmente en materia de derecho de los medios, generalmente asociado a la libertad de prensa y a la política comunicacional.

Tabla 6.3. Temática que sobresalió en Argentina

\begin{tabular}{|l|c|c|c|c|c|}
\hline Argentina & 2009 & 2010 & 2011 & 2012 & 2013 \\
\hline Derecho & 6 & 4 & 7 & 28 & 27 \\
Libertad de prensa & 4 & 2 & 10 & 12 & 16 \\
Política & 2 & 2 & 9 & 15 & 16
\end{tabular}

En Chile, se han destacado las estadísticas y los temas de derecho, con un crecimiento paralelo.

Tabla 6.4. Temática que sobresalió en Chile

\begin{tabular}{|l|c|c|c|c|c|}
\hline Chile & 2009 & 2010 & 2011 & 2012 & 2013 \\
\hline Estadística & 5 & 2 & 5 & 10 & 11 \\
Derecho & 3 & 3 & 7 & 10 & 11
\end{tabular}

En Ecuador, la temática ha sido y ha evolucionada en forma muy parecida a Argentin. Argentina.

Tabla 6.5. Temática que sobresalió en Ecuador

\begin{tabular}{lcc|c|c|c|} 
Ecuador & 2009 & 2010 & 2011 & 2012 & 2013 \\
\hline Derecho & 2 & 1 & 7 & 16 & 24 \\
Libertad de prensa & 2 & 1 & 14 & 27 & 20 \\
Política & 1 & 0 & 7 & 24 & 18
\end{tabular}

Agregamos Venezuela, donde sabemos que hay una alta conflictividad en torno a los medios de comunicación. Vemos que en los dos últimos años nos han llegado más noticias, especialmente relativas a la política de comunicación y la libertad de prensa.

Tabla 6.6. Temática que sobresalió en Venezuela

\begin{tabular}{l|c|c|c|c|c|}
\hline Venezuela & 2009 & 2010 & 2011 & 2012 & 2013 \\
\hline Libertad de prensa & 3 & 6 & 3 & 10 & 19 \\
Política & 4 & 3 & 3 & 6 & 20
\end{tabular}




\subsubsection{Implicados}

\subsubsection{Personas}

Como podemos ver en la tabla que sigue, las personas más citadas son predominantemente los jefes de estado y los que se destacan son los de países en que son también más frecuentes los problemas de la prensa.

\begin{tabular}{|c|c|}
\hline Personas & Frec. \\
\hline Correa, Rafael & 51 \\
\hline Fernández de Kirchner, Cris & 32 \\
\hline Chávez, Hugo & 19 \\
\hline Morales, Evo & 18 \\
\hline Maduro, Nicolás & 14 \\
\hline Peña Nieto, Enrique & 12 \\
\hline Calderón, Felipe & 9 \\
\hline Rousseff, Dilma & 9 \\
\hline Sánchez, Yoani & 9 \\
\hline Slim, Carlos & 9 \\
\hline Piñera, Sebastián & 8 \\
\hline González-Sinde, Ángeles & 7 \\
\hline Lobo, Porfirio & 7 \\
\hline Humala, Ollanta & 6 \\
\hline Vargas Llosa, Mario & 5 \\
\hline Assange, Julian & 4 \\
\hline Huffington, Arianna & 4 \\
\hline Reding, Viviane & 4 \\
\hline Insulza, José Miguel & 3 \\
\hline La Rue, Frank & 3 \\
\hline Martinelli, Ricardo & 3 \\
\hline Santos, Juan Manuel & 3 \\
\hline
\end{tabular}

\subsubsection{Categorías de personas}

Dado que aparecen frecuentemente personas menos relevantes, no se registraban sus nombres sino solo su función (lo cual se hizo también con las anteriores). Los periodistas, los presidentes (de países o corporaciones) y los usuarios han sido las personas más mencionadas en las noticias captadas (Tabla 8). Los funcionarios y miembros de los diversos poderes del Estado, sumándolos, superan el 20\%.

\subsubsection{Instituciones y organismos}

También registramos el nombre de insituciones y organismos, junto con su función. En la Tabla 9 aparecen los más frecuentemente citados, destacándose algunas empresas mediales (como Clarín y Telefónica), redes sociales (Twitter y Facebook) y organismos internacionales (SIP, ONU, RSF, etc.). 
Tabla 8. Categorías de personas más mencionadas $(>1 \%)$

\begin{tabular}{l|c} 
Categoría & Porcentaje \\
\hline Periodista & $16.12 \%$ \\
Presidente & $14.10 \%$ \\
Usuario & $14.02 \%$ \\
Ejecutivo & $8.57 \%$ \\
Ministro & $4.98 \%$ \\
Parlamentario & $4.36 \%$ \\
Funcionario de gobierno & $3.19 \%$ \\
Empresario & $3.04 \%$ \\
Político & $2.65 \%$ \\
Autor & $2.41 \%$ \\
Ciudadano & $2.18 \%$ \\
Autoridad nacional & $2.10 \%$ \\
Docente & $2.10 \%$ \\
Juez & $2.02 \%$ \\
Investigador & $1.79 \%$ \\
Profesional & $1.64 \%$ \\
Experto & $1.40 \%$ \\
Funcionario internacional & $1.32 \%$ \\
Abogado & $1.25 \%$ \\
Delincuente & $1.25 \%$ \\
Cliente & $1.01 \%$
\end{tabular}

Tabla 9. Instituciones más citadas (>1\%)

\begin{tabular}{l|c}
\hline Instituciones & Frec. \\
\hline Clarín & 35 \\
Telefónica/Movistar & 33 \\
Twitter & 33 \\
Sociedad Interamericana de Prensa & 30 \\
Facebook & 26 \\
ComScore Inc. & 25 \\
Google & 25 \\
El País & 18 \\
Globovisión & 15 \\
Organización de las Naciones Unidas & 15 \\
Reporteros Sin Fronteras & 14 \\
Comisión Interamericana de Derechos Humanos & 13 \\
Televisa & 12 \\
Unión Europea & 11 \\
El Universo & 10 \\
Organización de Estados Americanos & 10 \\
YouTube & 10 \\
Amazon & 9 \\
El Mundo & 9 \\
Sociedad Latina de Comunicación Social & 8 \\
TV Azteca & 8 \\
Vodafone & 8
\end{tabular}




\subsubsection{Tipos de organismos}

Se reducen a 25 los diferentes tipos de organismos que han aparecido más frecuentemente (más de 1\% del total) en nuestras fuentes (Tabla 10). Los gobiernos han sido los más frecuentemente aludidos.

\begin{tabular}{lc}
\multicolumn{2}{c}{ Tabla 10. Tipos de organismos citados (>1\%) } \\
\hline Categoría & Porcentaje \\
\hline Gobierno nacional & $8.42 \%$ \\
Periódico & $7.78 \%$ \\
Asociación de profesionales & $5.22 \%$ \\
Sitio Web & $5.12 \%$ \\
Parlamento & $5.02 \%$ \\
Televisora & $4.33 \%$ \\
Medio de comunicación masiva & $4.04 \%$ \\
Empresa de telecomunicación & $3.94 \%$ \\
Tribunal & $3.59 \%$ \\
Empresa de Investigación & $3.35 \%$ \\
Organismo internacional & $2.81 \%$ \\
Empresa de Internet & $2.61 \%$ \\
Empresa periodística & $2.46 \%$ \\
Organización Filantrópica & $2.46 \%$ \\
Defensora de derechos & $2.41 \%$ \\
Ministerio/Secretaría de (Tele)comunicación & $2.31 \%$ \\
Asociación de medios de comunicación & $2.26 \%$ \\
Oficina estatal & $2.26 \%$ \\
Universidad & $2.12 \%$ \\
Comisión estatal & $1.58 \%$ \\
Empresa de informática & $1.58 \%$ \\
Organismo regulador estatal & $1.58 \%$ \\
Partido político & $1.53 \%$ \\
Cibercomunidad & $1.33 \%$ \\
Ministerio & $1.08 \%$
\end{tabular}

\subsubsection{Síntesis por país}

Mostraremos aquí los principales resultados obtenidos por país, sin entrar en el detalle de las noticias.

\subsubsection{Argentina}

$\mathrm{N}^{\circ}$ de noticias: 139

Temas destacados: derecho, libertad de prensa, política

Personas más mencionadas: presidente, parlamentario, periodista

Organismos más mencionados: gobierno nacional, empresa periodística

\subsubsection{Bolivia}

$\mathrm{N}^{\circ}$ de noticias: 40

Temas destacados: política 
Personas más mencionadas: presidente, ministro, ejecutivo (de empresa)

Organismos más mencionados: asociación de medios de comunicación

\subsubsection{Brasil}

$\mathrm{N}^{\circ}$ de noticias: 51

Temas destacados: política, ciencia

Personas más mencionadas: presidente, ejecutivo, periodista

Organismos más mencionados: gobierno nacional, periódico

\subsubsection{Chile}

$\mathrm{N}^{\circ}$ de noticias: 128

Temas destacados: estadística, derecho

Personas más mencionadas: usuario, ejecutivo, presidente

Organismos más mencionados: secretaría de telecomunicaciones, gobierno nacional

\subsubsection{Colombia}

$\mathrm{N}^{\circ}$ de noticias: 36

Temas destacados: ciencia, política

Personas más mencionadas: periodista, presidente, usuario

Organismos más mencionados: organización filantrópica, gobierno nacional

\subsubsection{Costa Rica}

$\mathrm{N}^{\circ}$ de noticias: 5

Temas destacados: cultura

Personas más mencionadas: periodista, presidente, usuario

Organismos más mencionados: tribunal

\subsubsection{Cuba}

$\mathrm{N}^{\circ}$ de noticias: 10

Temas destacados: política

Personas más mencionadas: autor, artista

Organismos más mencionados: gobierno nacional, asociación de profesionales

\subsubsection{Ecuador}

$\mathrm{N}^{\circ}$ de noticias: 106

Temas destacados: derecho, libertad de prensa, política

Personas más mencionadas: periodista, presidente, ejecutivo

Organismos más mencionados: asociación de profesionales, gobierno nacional

\subsubsection{El Salvador}

$\mathrm{N}^{\circ}$ de noticias: 6

Temas destacados: política, educación 
Personas más mencionadas: periodista, presidente

Organismos más mencionados: asociación de profesionales, parlamento

5.3.4.10. España

$\mathrm{N}^{\circ}$ de noticias: 465

Temas destacados: estadística, derecho, ciencia

Personas más mencionadas: usuario, ejecutivo, ministro

Organismos más mencionados: empresa de telecomunicación, empresa de investigación

\subsubsection{Guatemala}

$\mathrm{N}^{\circ}$ de noticias: 3

Temas destacados: política

Personas más mencionadas: periodista

Organismos más mencionados: sociación de profesionales, gobierno nacional

\subsubsection{Honduras}

$\mathrm{N}^{\circ}$ de noticias: 21

Temas destacados: política

Personas más mencionadas: presidente, ejecutivo, político

Organismos más mencionados: gobierno nacional, parlamento

\subsubsection{México}

$\mathrm{N}^{\circ}$ de noticias: 195

Temas destacados: derecho, periodismo

Personas más mencionadas: periodista, presidente, empresario, funcionario de gobierno

Organismos más mencionados: parlamento, comisión estatal, gobierno nacional

\subsubsection{Nicaragua}

$\mathrm{N}^{\circ}$ de noticias: 9

Temas destacados: política

Personas más mencionadas: periodista, autoridad nacional

Organismos más mencionados: partido político, asociación de empresas

\subsubsection{Panamá}

$\mathrm{N}^{\circ}$ de noticias: 11

Temas destacados: cultura

Personas más mencionadas: periodista, presidente, ciudadano

Organismos más mencionados: asociación de profesionales, congreso/exposición

\subsubsection{Paraguay}

$\mathrm{N}^{\circ}$ de noticias: 4 
Temas destacados: -

Personas más mencionadas: funcionario de gobierno

Organismos más mencionados: gobierno nacional

\subsubsection{Perú}

$\mathrm{N}^{\circ}$ de noticias: 40

Temas destacados: cultura, política, ciencia

Personas más mencionadas: autor, político, ministro

Organismos más mencionados: asociación de profesionales, gobierno nacional

\subsubsection{República Dominicana}

$\mathrm{N}^{\circ}$ de noticias: 3

Temas destacados: política

Personas más mencionadas: ministro, presidente

Organismos más mencionados: gobierno nacional, asociación de profesionales

\subsubsection{Uruguay}

$\mathrm{N}^{\circ}$ de noticias: 2

Temas destacados: política

Personas más mencionadas: funcionario internacional, presidente

Organismos más mencionados: gobierno nacional, asociación de medios de comunicación

\subsubsection{Venezuela}

$\mathrm{N}^{\circ}$ de noticias: 63

Temas destacados: libertad de prensa, política

Personas más mencionadas: autoridad nacional, periodista, ejecutivo

Organismos más mencionados: televisora, gobierno nacional

Estos pocos datos de cada país son suficientes par darse cuenta de diferencias substanciales entre ellos pero, a este nivel, bastaría probablemente con leer tres o cuatro noticias para darse cuenta de lo mismo, sin necesidad del trabajo realizado aquí. Si bien es posible profundizar más, sería necesario para ello transcribir las noticias.

\subsection{Conclusión}

No ha sido nuestro principal objetivo lograr el esbozo de un panorama regional coherente y detallado en materia de comunicaciones. No aporta mucho conocimiento concluir que, globalmente, en esta materia, predominan problemas relacionados con la 
política gubernativa y el derecho, y que -aparte de ello- la publicación de datos estadísticos es también frecuente. Los objetos de las estadísticas, las orientaciones de las políticas y el núcleo de las discusiones de derecho deberían ser mencionados, pero se requiere para ello acumular las noticias en un sistema como el que hemos construído y, a partir de su motor de búsqueda, recuperar noticias que respondan a un mismo par de descriptores (parecido al que mostramos en el numeral 4.2.2, con el contexto asociado a declaraciones del presidente Humala de Perú). Y aún con tal sistema, se necesitaría un largo análisis "manual" para hacer comparaciones y sacar conclusiones más precisas que los resultados estadísticos que hemos expuesto aquí.

Habrá quedado claro que no es fácil lograr una visión coherente, con datos específicos comparables, de lo que ocurre en materia de comunicaciones en la región iberoamericana. En la práctica, queda fuera de las posibilidades de los particulares y este tipo de empresa parece más propio de centros de investigación que obtengan la información por medios diferentes de la prensa. En algunos países existen organismos que lo hacen.

También creemos haber establecido que, para una difusión amplia que responda a intereses particulares como en nuestro caso, la sindicación de contenidos (RSS) resulta ser un mecanismo vital para los diarios. Y para los lectores, correlativamente, son importantes las aplicaciones de lectura de RSS que cuenten con filtros, como la G2reader, que permiten un acceso más rápido a las noticias de interés (Gráfico 3). Google News tiene cierto interés en cuanto aporta una selección de noticias sobre libertad de prensa y libertad de expresión pero, lamentablemente, no ofrece otros filtros de interés en nuestro campo.

Para los interesados, sigo publicando mi selección de noticias sobre comunicaciones iberoamericanas en Flipboard: https://flipboard.com/section/comunicaciones-iberoamericanas-buCdsZ

\subsection{Bibliografía}

Colle, R. (2002): Explotar la Información Noticiosa - Data Mining aplicado a la Documentación Periodística, Ed. Depto de Biblioteconomía y Documentación, Madrid, Universidad Complutense.

Colle, R. (2000): Análisis lógico de hechos noticiosos, Revista Latina de Comunicación Social, n.27, http://www.revistalatinacs.org/aa2000tma/126colle.html

Colle, R. (1992): Documentación periodística: Principios y aplicaciones, Santiago de Chile, Ed. Pontificia Universidad Católica. 


\title{
6
}

\section{La prensa digital en España: los errores del pasado, las oportunidades del futuro}

\author{
Jaime Novoa \\ Titulado en Universidad de Santiago de Compostela \\ Redactor en Weblogs SL \\ jaimenovoa@gmail.com
}

Este texto fue publicado orginalmente en la revista Genbeta.com (09/01/2014). Aunque no constituye un texto propiamente académico, se estimó que su contenido sería de especial interés a modo de conclusión de la presente obra ${ }^{6}$.

Reproducido con autorización del autor y de la revista.

\subsection{Introducción}

Pocos sectores se han visto tan impactados por internet como el del periodismo. Medios y periódicos de todo el mundo se vieron sorprendidos de golpe y porrazo por la era digital, provocando una importante caída de la inversión publicitaria en los medios -su principal modelo de negocio- y en el número de ejemplares vendidos.

Con la "caída" de los históricos hemos asistido también a la creación de nuevos medios basados en una estrategia puramente digital. Con estructuras adecuadas al contexto actual, medios como eldiario.es o El Confidencial han conseguido hacerse un lugar en el panorama de la información española. Otros, como El Mundo, El País o La Voz de Galicia, han intentado adaptarse a los nuevos tiempos con medidas drásticas (recortes de plantilla, presupuestos, etc) y la búsqueda del equilibrio entre la información gratuita y de pago. En esta entrada hablamos con representantes de tres importantes medios españoles: Marilín Gonzalo, Jefa de Producto en eldiario.es; Pablo

5 http://www.genbeta.com/web/la-prensa-digital-en-espana-los-errores-del-pasado-las-oportunidades-del-futuro

6 La numeración de apartados es nuestra (En el texto original no la hay). 
Romero, editor de El Mundo; y Tomás García, director de la Edición Digital de La Voz de Galicia.

\subsection{Del papel hacia lo digital}

Durante más de cincuenta años medios de comunicación y periódicos españoles vivieron en la abundancia. La información estaba dominada por una serie de grupos editoriales -cada vez menos- que controlaban el acceso a la información en un sector que, dadas las características de lo físico, impedía la fácil entrada de competidores.

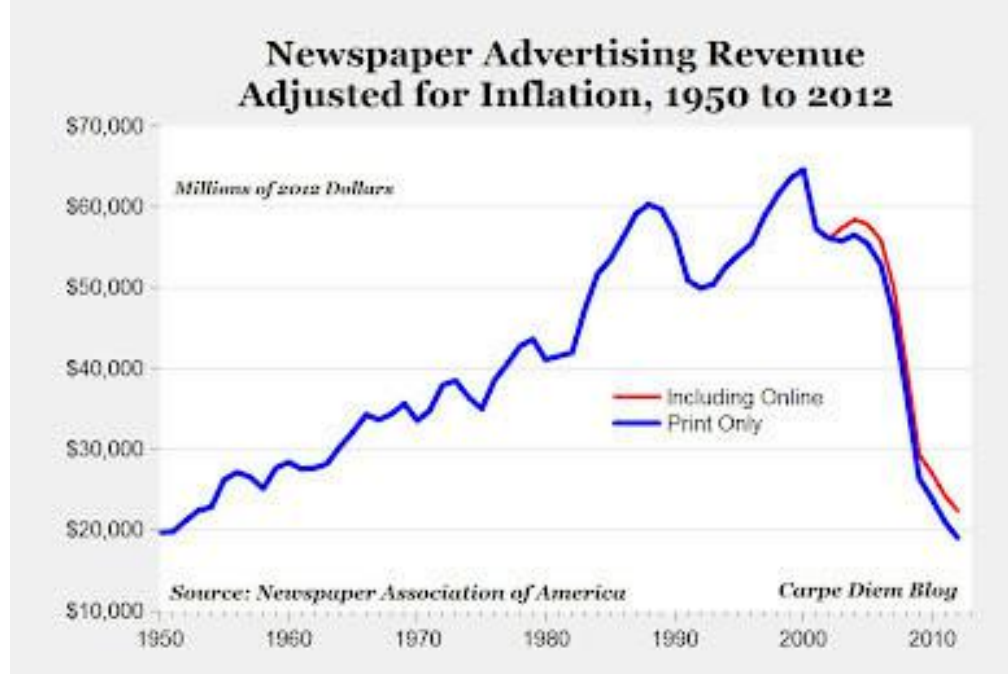

Inversión publicitaria en periódicos de EEUU - Vía Hipermediaciones

Pero internet cambió todo esto. No solo provocó la democratización de la información -otorgando un espacio en el que cualquier persona podía publicar sus textos, sus noticias- sino que además hizo que se tambaleasen los cimientos del modelo de negocio que habían sujetado -bien alto- a los medios: la publicidad. Las páginas web, los blogs, los banners, AdSense, AdWords y más tarde el native advertising y otros formatos desviaron gran parte de esa cuantiosa inversión publicitaria hacia internet, hacia lo digital.

Una "tormenta perfecta", así es cómo lo define Pablo Romero (El Mundo) en declaraciones a Genbeta:

"Crisis económica sin precedentes - uno de los primeros recortes que las empresas y los gobiernos llevan a cabo cuando no hay pasta es la publicidad, nuestra gasolina-; los enormes cambios que introduce Internet en la comunicación humana y que nos ha quitado el monopolio de la atención; dispersión de la inversión publicitaria (somos muchos medios que alimentar) y, por otro lado, concentración de la misma en manos de Google. Y para colmo, la concentración de medios y la salida a Bolsa de los grupos de 
comunicación. Esto último es imprescindible para comprender qué demonios pasa en esta industria."

Tomás García (La Voz de Galicia) apunta, además, en otra dirección: la "metamorfosis de la audiencia”, que pasa a tener al alcance de sus dedos información gratuita $-\mathrm{y}$ de nivel- cuando antes esto no era posible.

"Hemos sufrido una metamorfosis en nuestra audiencia, de manera que cada día tenemos más usuarios en productos gratuitos y menos compradores en el negocio tradicional. Aunque en el cómputo, cada vez tenemos más audiencia. Esto es así en España, y no en otros países. Por suerte, en el mercado español las grandes marcas periodísticas hemos sido capaces de trasladar el liderazgo que alcanzamos en el papel al nuevo escenario digital."

Unas estructuras empresariales ya establecidas ("Tampoco ayuda la inflación de jefes que hay en las redacciones", reflexiona Romero, "al final, los redactores de base parecemos una especie en extinción, somos casi los 'chicos para todo'; creo que eso no es bueno"), una nueva audiencia, una nueva forma de entender y producir la información que trajo importantes cambios a los medios tradicionales. Muchos redujeron significativamente sus plantillas al tiempo que intentaban reproducir los contenidos del papel en la web, mayoritariamente de forma gratuita.

Sin embargo, en los últimos años medios como El Mundo o La Voz de Galicia han comenzado a prestarle más atención a sus sectores digitales con el lanzamiento de iniciativas que combinan contenidos gratuitos y de pago.

\subsection{La información gratuita que ¿convive? con la de pago}

La información fue durante décadas exclusivamente de pago, controlada por medios y grupos editoriales. En el entorno actual el valor monetario de la información en sí (los artículos, las noticias) se diluye, en parte por el crecimiento exponencial de medios informativos y redes sociales.

Orbyt fue una de las primeras apuestas en España, por parte de El Mundo. Esta versión digital del periódico ha desembocado en una reorientación de la estrategia editorial del medio que dirige Pedro J. Ramírez ${ }^{7}$, apostando por el lanzamiento de apps móviles o ediciones vespertinas del noticiario.

Al respecto, Pablo Romero dice:

"La reducción de la plantilla se ha notado mucho, desgraciadamente, pero por otro lado ha habido una gran concienciación por parte de la redacción tradicional — de papel— de manera que ahora todos participan más en la versión web. Falta mucho camino por recorrer, ojo."

7 Como se sabe, dejó la dirección después de la publicación del artículo aquí recogido. (Nota del editor) 
Tomas García hace hincapié en la estrategia digital de La Voz de Galicia, su app de pago para iPad y versiones en PDF del periódico. "La filosofía de La Voz es seguir apostando por el digital, llevar cada vez una oferta más completa a cada uno de los dispositivos, y abrir nuevas vías de ingresos a partir de la fidelización de los lectores”, afirma.

Las características del ámbito digital permitieron también la creación de otros grupos editoriales y periodísticos. Eldiario.es es uno de ellos. Fundado y dirigido por Ignacio Escolar, eldiario.es combina información gratuita con planes de pago que permiten a sus socios acceder antes a determinados contenidos.

Marilín Gonzalo, Jefa de Producto del medio, al respecto de la combinación de información gratis y de pago, afirma:

"La clave principal para mí consiste en un equipo que comparte los valores que nos permiten mantener este modelo, que está basado en la calidad de los contenidos, en un compromiso con el rigor en la información y la transparencia. Otra de las claves es escuchar permanentemente a nuestra audiencia. En un primer momento en el lanzamiento de eldiario.es no se pensaba que los ingresos de los socios iban a ser tan importantes para el modelo de negocio, y luego fuimos viendo que la comunidad estaba dispuesta a pagar para apoyar la subsistencia del medio. Entendimos que nuestros socios no querían pagar para leer algo en exclusiva sino para que el periodismo que hacemos pueda ser leído por todos y seguir existiendo.

Y es que eldiario.es ha conseguido más de 5.300 socios en su primer año de vida, que aportaron 258.000 euros. Las ventas totales del medio en su primer año de vida alcanzaron los 841.000 euros, siendo la publicidad la principal fuente de ingresos del grupo. Con tan solo 21 trabajadores en su redacción, eldiario.es perdió tan solo 379 euros en sus primeros doce meses de vida. Aunque no directamente comparables, es importante destacar que Vocento perdió 8,2 millones de euros en la primera mitad de 2013; Prisa presentó unas pérdidas de 194 millones en los primeros nueve meses del año pasado.

Marilín Gonzalo también habló sobre los problemas de los medios que vienen del papel y de los importantes cambios que han sufrido en los últimos tiempos:

"Dejaron de apostar por nuevos formatos, y dejaron en manos de gestores económicos la dirección de los medios. Un medio de comunicación es algo más que una empresa, entre sus objetivos está el de ganar dinero pero también tiene un compromiso con la verdad y con la función que cumplen los medios en una democracia.

Los que ignoraron a internet hace años también se encuentran ahora con un retraso para poner al día a sus equipos y sobre todo a sus estructuras. No sólo en papel, también en digital: los redactores que no hicieron bien su trabajo, que olvidaban el fact-checking, los editores que no querían renunciar a un titular impactante por uno veraz, que relajaron su compromiso con la verdad, los que se apoltronaron en un puesto sin ponerse al día de lo que estaba sucediendo en las redes, sin cuestionar decisiones, cayendo en la autocomplacencia y en el corporativismo y sin escuchar las críticas de sus lectores, ciertamente también contribuyeron a terrible situación de la profesión. 


\subsection{El periodismo, ¿en peligro?}

Han sido muchas las voces que en los últimos años han manifestado que el periodismo estaba de capa caída. Bien por cuestiones monetarias, informativas o de otra naturaleza, algunos creen que internet ha cambiado el mundo de la información a peor. Los blogs y las redes sociales han dado voz a un sinfín de personas -anónimas o no- que se han convertido en creadores de contenidos, de noticias, de piezas.

Sobre el impacto de internet y el blogging también quisimos hablar con nuestros invitados y esto es lo que comentaron al respecto. ¿Está el periodismo en peligro? ¿Ha sido la influencia de blogs y la información gratuita malo para el sector y la sociedad?

\section{Tomás García (La Voz de Galicia):}

"El consumo de noticias, el interés de los ciudadanos por saber qué está ocurriendo, la necesidad de la gente por compartir contenidos y debatir sobre ellos,... todo eso está viviendo su mayor época de esplendor. Todo eso crece y otros ingredientes del periodismo como la reflexión, la lectura pausada, el análisis, están un período de decadencia. Pero no me atrevo a echarle la culpa a Internet, sino a un cambio de hábitos motivado, es cierto, por la evolución tecnológica."

\section{Marilín Gonzalo (eldiario.es):}

"Todo lo contrario, pero con matices. Internet y sobre todo los blogs son parte de una transformación que nos ha hecho comunicarnos más, informarnos más, entender mejor la producción de contenidos y aprender a publicar por nosotros mismos, sin pasar por un editor o una dirección que muchas veces se comporta más como empresa que como medio.

La prensa está en crisis y lleva en crisis un tiempo, no por internet, sino porque se han cometido muchos errores de forma sistemática."

\section{Pablo Romero (El Mundo):}

"No creo que el periodismo esté en peligro, pero sí opino que se convertirá en una profesión minoritaria, casi elitista. Las redacciones han adelgazado mucho y los que nos podemos dedicar a esto somos cada vez menos. No creo que Internet o los blogueros hayan cambiado nada en lo que al periodismo se refiere. Es más, ambos fenómenos han sido claves para descubrir extraordinarios profesionales que, de otro modo, no hubieran tenido ninguna oportunidad."

\subsection{La necesidad o no de una 'tasa Google'}

Los buscadores y agregadores de contenidos se han encontrado en ocasiones en el punto de mira de los grupos editoriales. Gobiernos y grupos de medio mundo se han quejado ante organismos públicos del papel de este tipo de servicios, que enlazan y 
agregan contenidos de los medios. A veces, según defienden los dirigentes de El Mundo, robándole audiencia y por lo tanto una parte del pastel publicitario a los medios.

Google es, sin ninguna duda, el que más críticas ha recibido tanto por su buscador como por Google News. La tasa Google busca algún tipo de compensación por parte de los buscadores que agregan los artículos y las noticias. Pablo Romero (El Mundo) opina al respecto diciendo que "el problema es que Google, en realidad, no vive realmente de esos contenidos. No son esenciales para su gigantesco mercado publicitario".

Considera que "es legítimo protestar y pedir amparo legal si Google usa tu material para presumir de que en Google News puedes informarte mejor que en tu sitio. Parece algo un poco "parásito", continúa.

Marilín Gonzalo se muestra totalmente opuesta a este tipo de tasas o penalizaciones:

"Esto es una locura. ¿En qué se fundamenta esa tasa? En que un sector (la industria que produce contenidos) presiona al gobierno para eso. Google no obliga a ningún medio a incluirse en sus resultados: es tan simple como agregar una línea de código llamada norobots.txt a tu página y ya estás fuera de Google."

En algo en lo que todos están de acuerdo es en que Google es un partner importante y necesario en el mundo de la información e internet. Romero reflexiona: "A ver qué medio tiene los huevos de salir en Internet y evitar que Google te enlace. ¿Realmente te interesa salir de Google si la compañía no te paga (aunque sea una limosna, como en Francia)?” 